فاعلية برناهج ارشادي عقلاني انفعالي لففض أعراض القلق وتشين جودة الحياة لدى طلاب الجاهعة ذوي الاضطرابات السيكوسوهاتية

\title{
د/ داليا نبيل حانظ
}

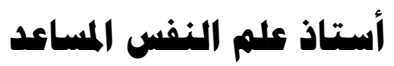

رئيس قسم علم النفس - جاهعة حلوان

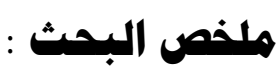

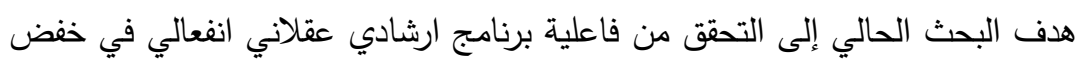

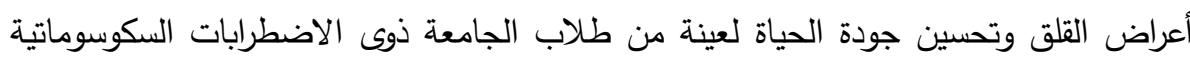

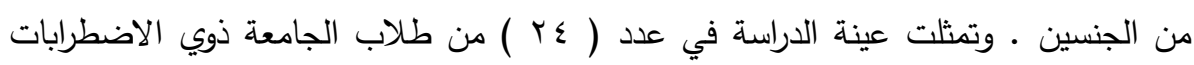

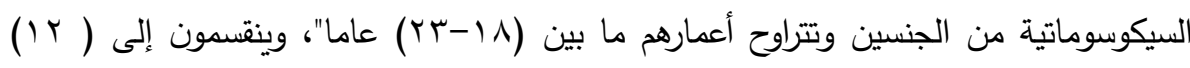

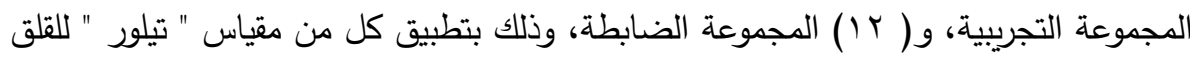

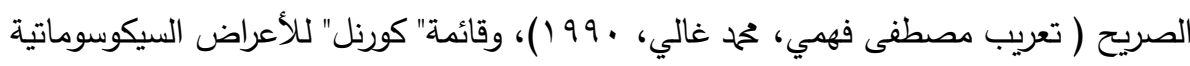

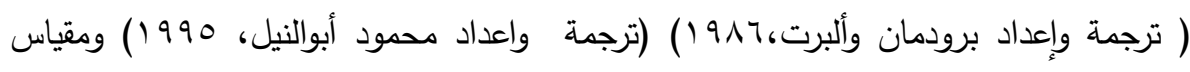

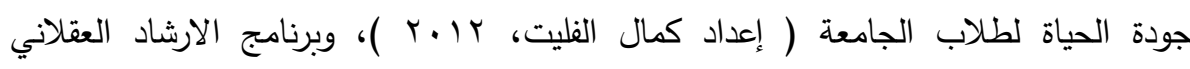

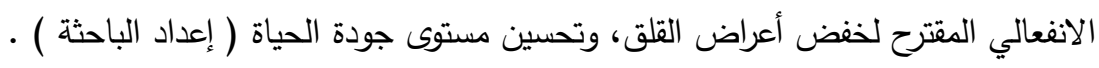

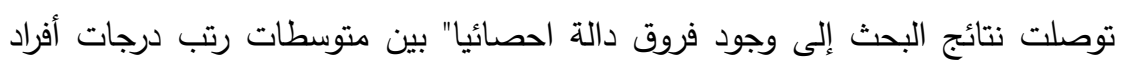

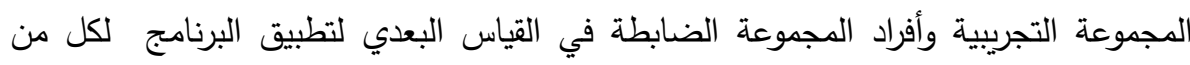

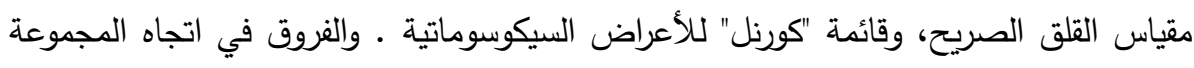

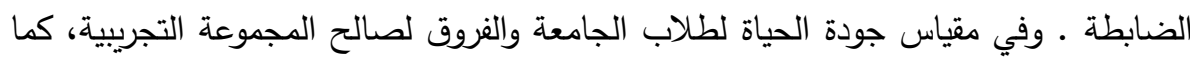

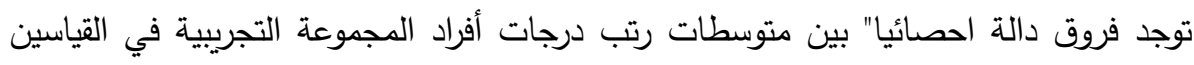

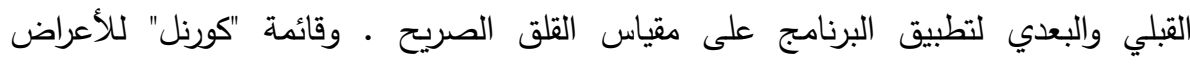

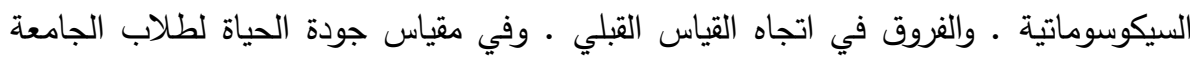

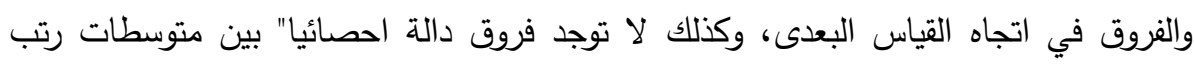

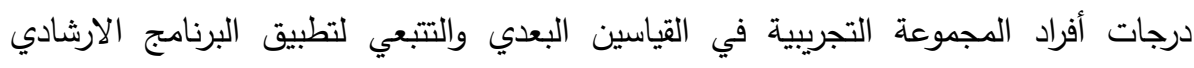

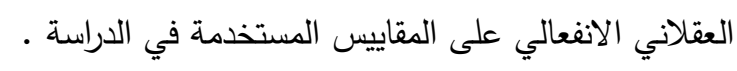


فاعلية برناهمج ارشادي عقلاني انفعالي لذفض أعراض القلق وتمسين جودة الهياة لدى طلاب الجاهمة ذوي الاضطرابات السيكمسوماتية

\section{د/ داليا نبيل حافظ}

أستاذ علم النفس المساعد

رئيس قسم علم النفس - جاهعة حلوان

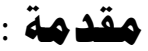

حاز موضوع الاضطرابات السيكوسوماتية وتفسيراتها على إهتمام واسع من الدراسات العلمية منذ منتصف القرن التاسع عشر نظرا" للعلاقة الوثيقة بين النفس والجسد وأهمية

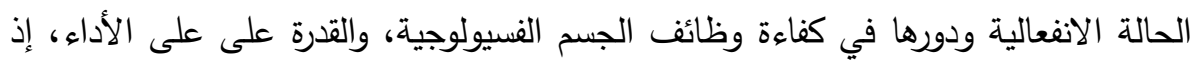
تعمل العلاقة بين الجسم والنفس على الاحتفاظ بالتوازن المناسب لممارسة الوظائف السيكولوجية والجسدية بكفاءة وفاعلية . تعملية

وقد امتد هذا الاهتمام أيضا" ليشمل دراسة عوامل التفكير وطبيعة المعتقدات حيث وجد الباحثون أن الاستجابات النفسية والجسدية تتشكل بفعل الطريقة التي يفكر بها الفرد ويقيم

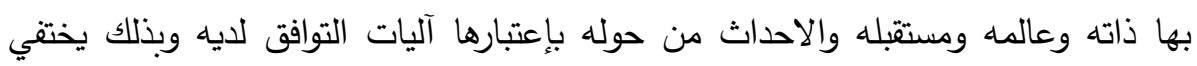
الخط الفاصل بين الجسد والعقل بفضل ما توصل إليه العلماء من وجود علاقة مباشرة بين الاضطرابات الجسمية والانفعال وطريقة التفكير · ( Bootzin et al., 1993:214 ) وقد أوضحت العديد من الأبحاث وجود علاقة ارتباطية دالة بين معاناة الفرد من الاضطرابات النفسجمية وبين الشعور بالقلق وانخفاض مستوى جودة الحياة لديه وما يرتبط

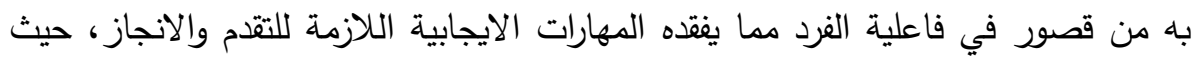

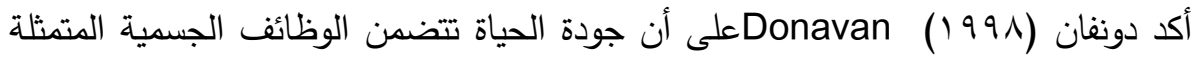
في انجاز الأنشطة الاجتماعية واليومية والرضا عن الحياة بشكل عام (تامر الراجي، لبحني،

$$
\text { ( } r \leqslant 09-r \leqslant 01, r \cdot 1 r
$$

كما تثير العديد من الدراسات والملاحظات العيادية إلى التأثيرات السلبية للعوامل

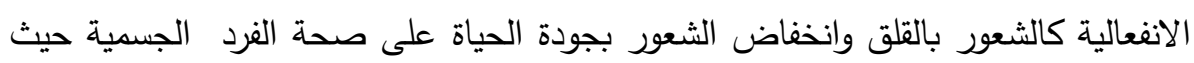

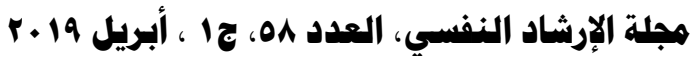

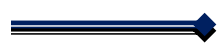




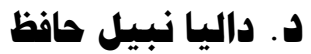

تؤدي لآثار ضارة على القلب والأوعية الدموية، والغدد الصماء ووظائف المناعة

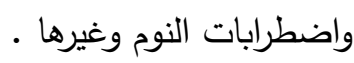

ويؤكد العديد من الباحثين على أن العلاقة بين الاضطرابات السيكوسوماتية والاضطرابات

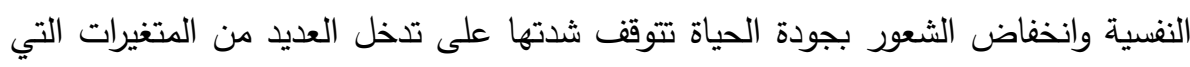

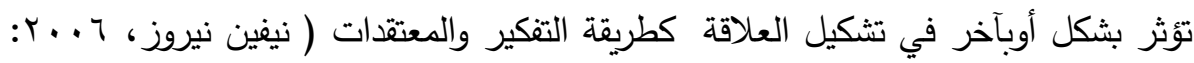

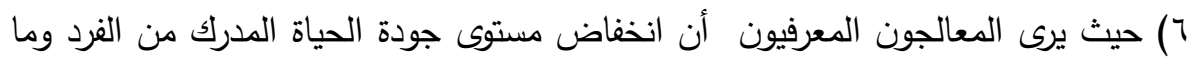

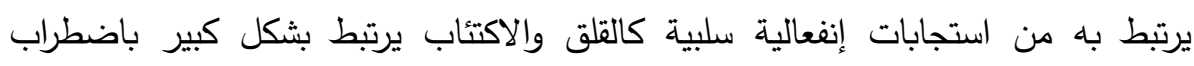

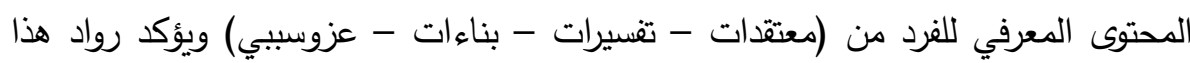

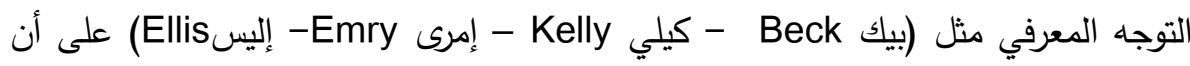

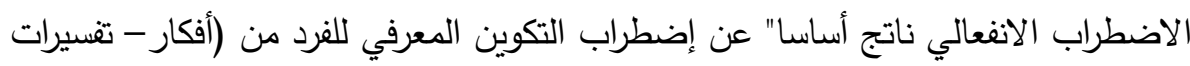

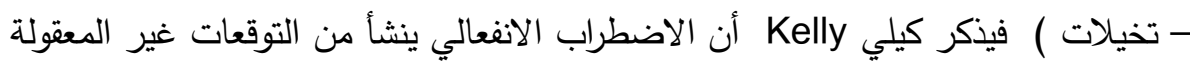

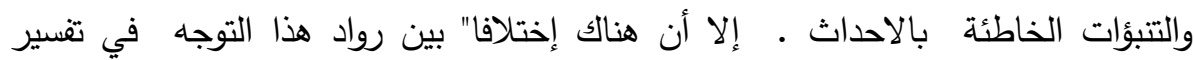
خصوصية الدور المعرفي في إحداث وإستمرار الاضطراب ، حيث أكد إليس Ellis على الإنى

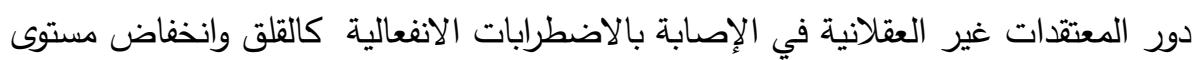

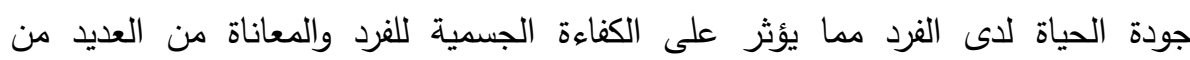
الأعراض الجسمية مثل الصداع النصفي، وقرحة المعدة ودقات القلب غير المنتظمة وغيرها

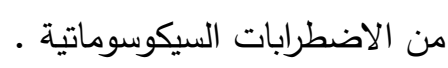

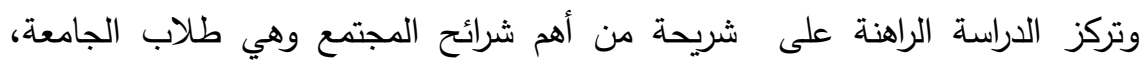

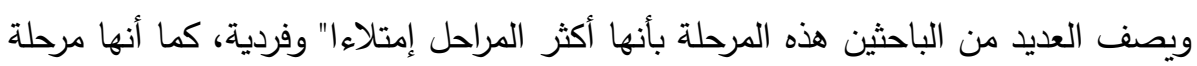

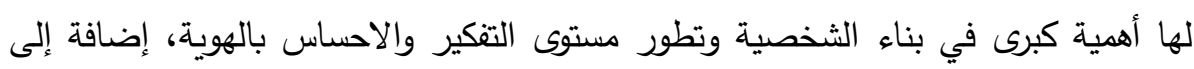

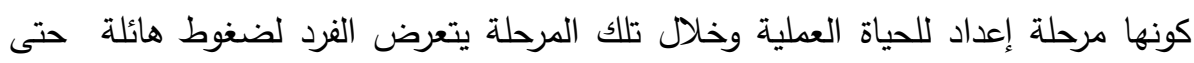

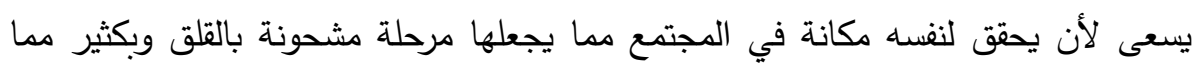

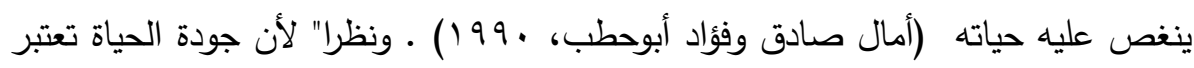

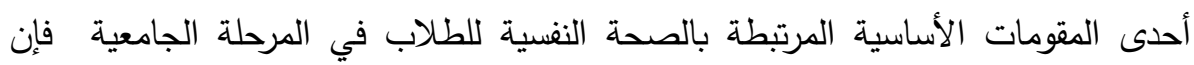

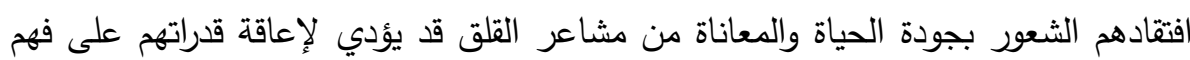

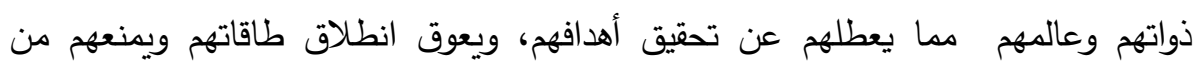

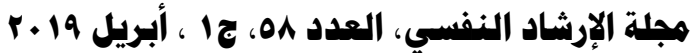


توظيف إمكاناتهم كما يقلل من مستوى انجازهم الأكاديمي • وقد يحدث أن يصرف هؤلاء

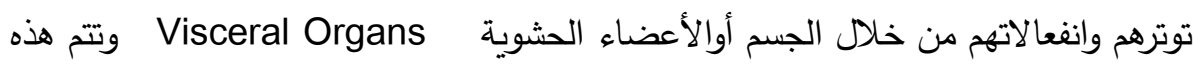
العملية على المستوى اللاشعوري بدون وعي ولذلك لايدركون الأسباب الحقيقية وراء آلامهم

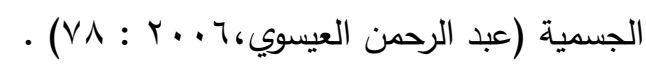

وقد أظهرت العديد من الملاحظات العيادية أن كثير من طلاب الجامعة الذين يعانون من الاضطرابات السيكوسوماتية يتبنون بعض الاعتقادات غير العقلانية والأفكار الخاطئة والاستتاجات المغلوطة والمفاهيم الخاطئة عن الذات والآخرين العالم والمستقبل مستندين الاعنين

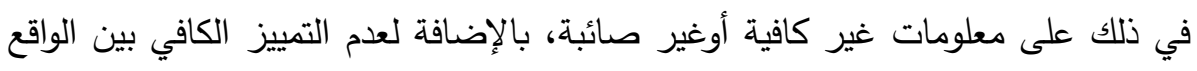

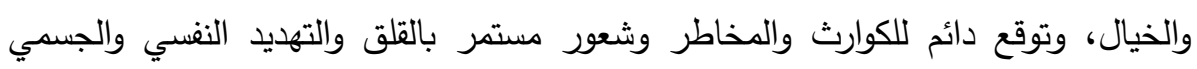

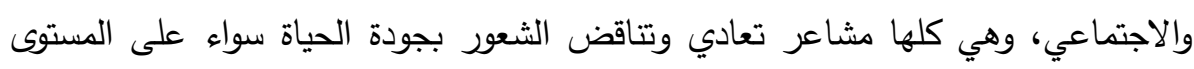
الشخصي أوالاجتماعي أوالمادي أوالاكاديمي

ويهدف الارشاد العقلاني الانفعالي إلي إعادة البناء المعرفي للفرد من خلال استخدام

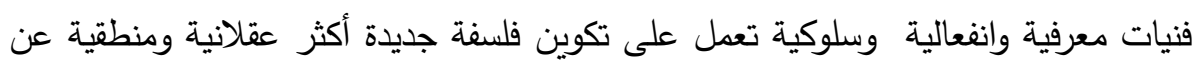
طريق التدريب على استخدام طرق واستراتيجيات التفكير العقلاني الايجابي (Ellis,1990)

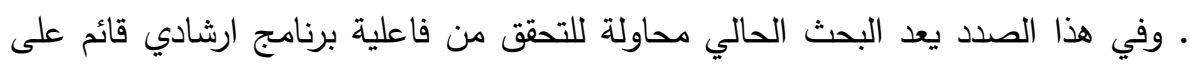
المنهج العقلاني الانفعالي يهدف إلى خفض أعراض التقل وتحسين مستوى الشعور بجودة الحياة لدى طلاب الجامعة من الجنسين ذوي الاضطرابات السيكوسوماتية، من خلال

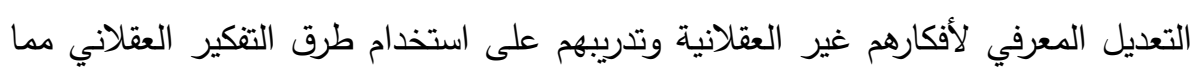

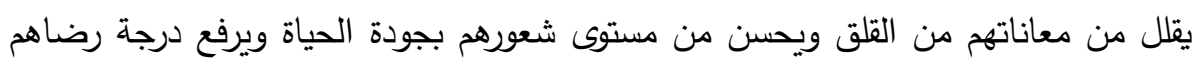

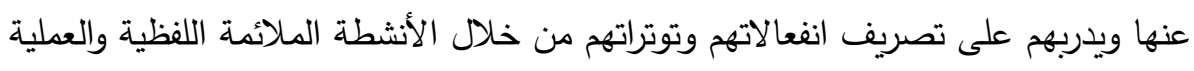
بدلا" من تصريفها من خلال الجسد ومن ثم ينعكس ذلك أيجابيا" على خفض معاناتهم من

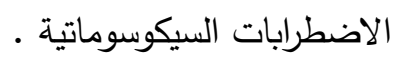

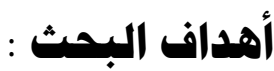

تهدف الدراسة الحالية إلى تحقيق عدد من الأهداف الأساسية كما يلي : 
1-الوقوف على طبيعة العلاقة بين الأفكار اللاعقلانية وبين كل من أعراض القلق ومستوى

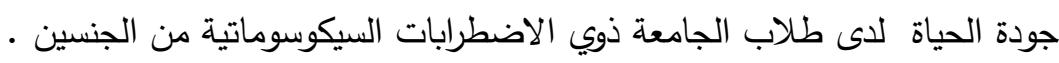

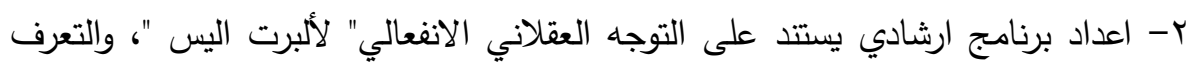

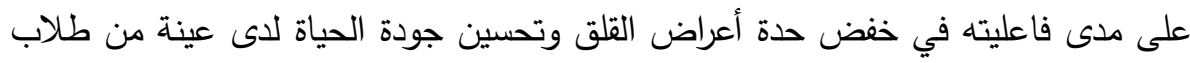
الجامعة من الجنسين ممن يعانون من الاضطرابات السيكوسوماتية من خلال إعادة الهيكلة

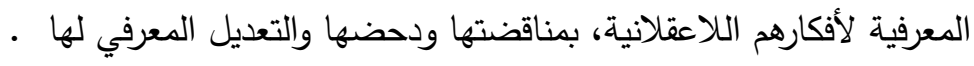

تتحدد الأهمية النظرية للبحث في النقاط التالية :ا-تمثل مشكلة الاضطرابات السيكوسوماتية Psychosomatic Disorders متزايدة في عصرنا الحديث بسبب منغصات الحياة التي تتزايد كل يوم وتعقد الظروف

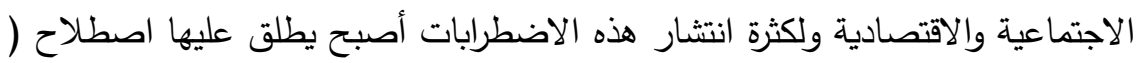

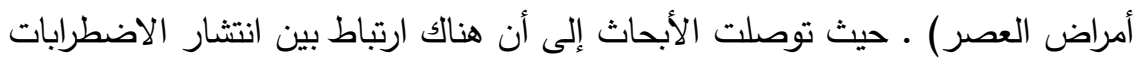

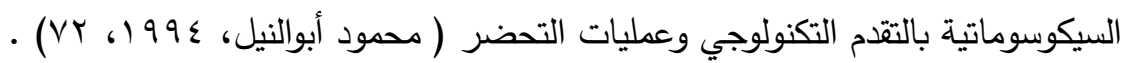
r- تعود أهمية هذا البحث إلى توجيه انتباه الباحثين إلى مفهوم حديث ينتمي لعلم النفس بلى بلى

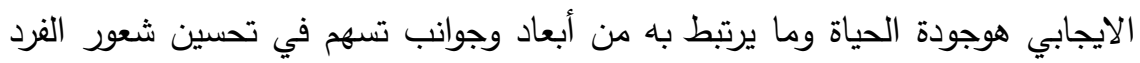
بجودة الحياة وما يتعلق به من تحسن الصحة النفسية للفرد وزيادة فاعليته وكفائته

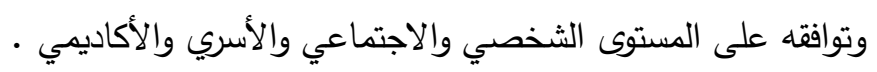
ب-يركز البحث الحالي على شريحة هامة في المجتمع وهي شريحة طلاب الجامعة والتي ولتئي

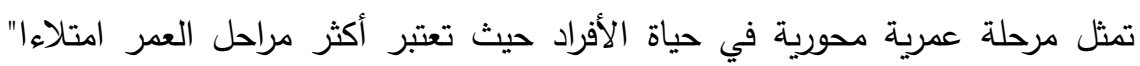
بالأمال والطموحات والطاقات والسعى لتحقيق المكانة في المجتمع والاستعداد للحياة العملية مما يجعلها مرحلة مشحونة بالقلق تؤثر سلبيا" على مستوى شعورهم بجودة الحياة ولهات وقد يسبب ذلك لبعضهم وخاصة من تتسم طرق تفكيرهم بعدم الواقعية وغير العقلانية اضطرابات انفعالية كالتقلق والاكتئاب والتي تعبر عن نفسها في شكل اعراض جسمية

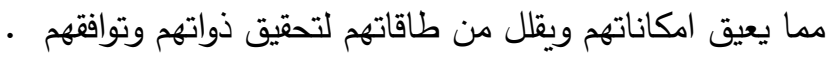

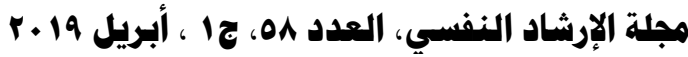


ع - القصور في الخدمات التأهيلية المقدمة لطلاب الجامعة ذوي الاضطرابات السيكوسوماتية في ظل غياب أساليب العلاج النفسي والمعرفي الفعالة التي يمكن أن الن النيل

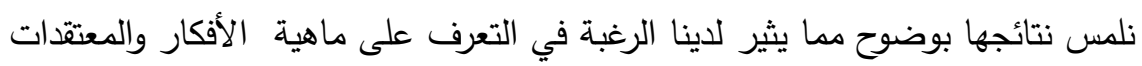
اللاعقلانية والمفاهيم الخاطئة لديهم وتصحيحها وتعليمهم طرق التفكير المنطقي والعقلاني الأمر الذي يساعدهم في التغلب على مشاعر القلق وتحسين مستوى جودة

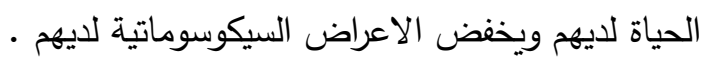
*الأهمية التطبيقية للبحث :-

يعد البحث الراهن محاولة لتوظيف نظريات علم النفس العلاجي والإرشادي ومناهجه وخاصة المنهج العقلاني الإنفعالي والتي تقيد في عمليات التتبؤ والإرشاد النفسي والمعرفي

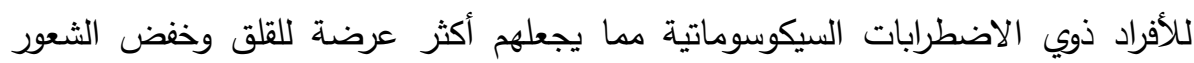
بجودة الحياة، وتقديم المساعدة النفسية المتخصصة لهم من ناحية، وكذلك الإعداد لبرنامج إرشادي عقلاني انفعالي يهدف إلى تبصيرهم وتوعيتهم بدور الأفكار غير العقلانية والمفاهيم

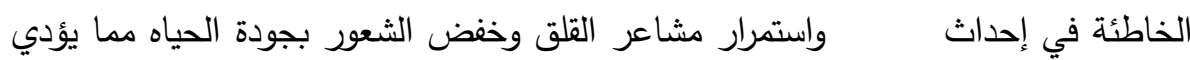
للاضطرابات السيكوسوماتية حيث يتمثل التتخل الارشادي في تعديل تلك الأفكار

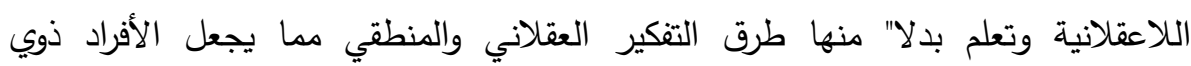
الاضطراب السيكوسوماتي أكثر كفاءة وفاعلية في حياتهم ويساعدهم على الاحتفاظ بسلامتهم الجسمية والنفسية والتي تعد كفاءة الجسد من أهم أركانها مما يخفض لدئل الديهم القلق،

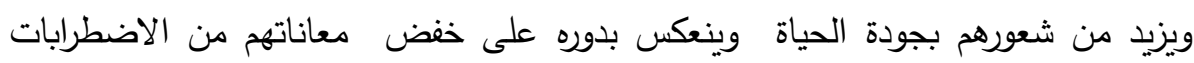
السيكوسوماتية .

\section{مشكلة الدراسة وتساؤلاتها :}

حظيت دراسة الاضطرابات السيكوسوماتية في علاقتها بالعديد من المتغيرات النفسية

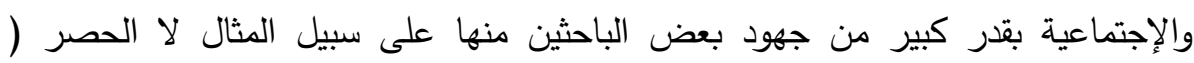
الاضطرابات السيكوسوماتية وعلاقتها بالضغوط - الاضطرابات السيكوسوماتية وعلاقتها بنمط الشخصية، وكذلك الاضطرابات السيكوسوماتية وعلاقتها بالقلق والاكتئاب .......

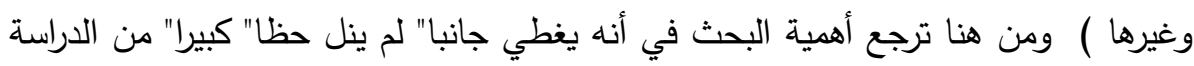

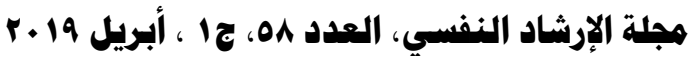




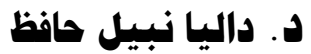

وهواعداد وتصميم برنامج ارشادي قائم على استراتيجيات التنكير العقلاني الانفعالي، وفنيات

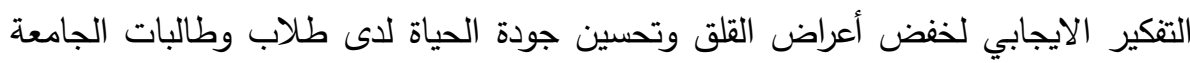
ذوي الاضطرابات السيكوسوماتية من الجنسين من ناحية ـ كما تحاول الدراسة الراهنة تثكيل

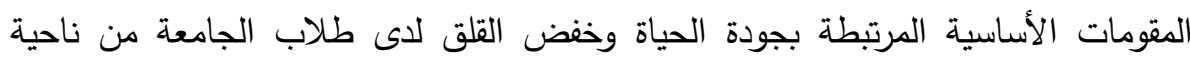

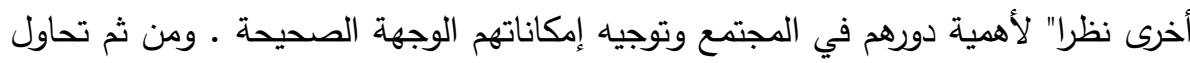

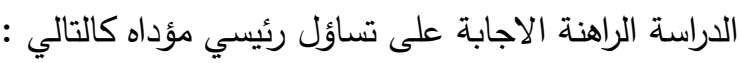

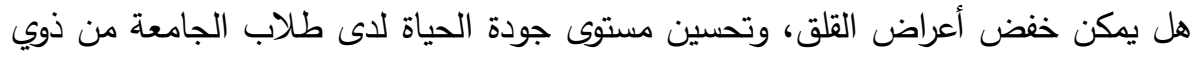

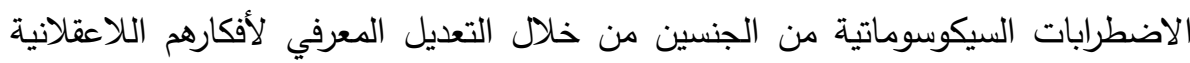
واستبدالها بأخرى أكثر عقلانية بعد تطبيق برنامج ارشادي قائم على الإنى النظرية العقلانية

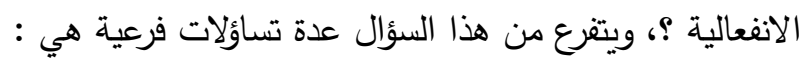
وتتبلور مشكلة الدراسة في التساؤلات التالية : 1-هل توجد فروق بين درجات طلاب وطالبات الجامعة ذوي الاضطرابات السيكوسوماتي

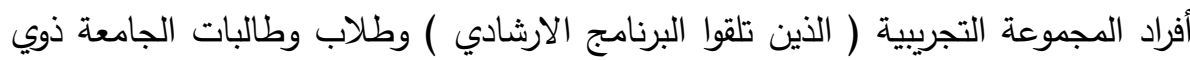

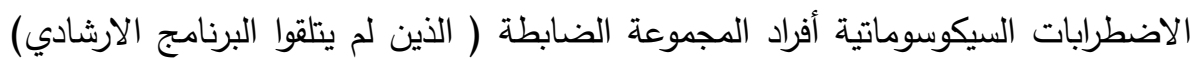

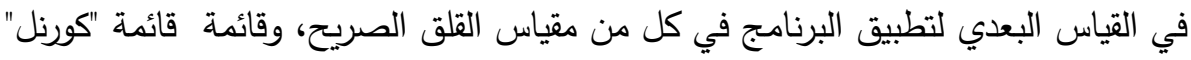
لكأعراض السيكوسوماتية، ومقياس جودة الحياة لطلاب الجامعة ؟ r- هل توجد فروق بين درجات طلاب وطالبات الجامعة ذوي الاضطرابات السيكوسوماتية

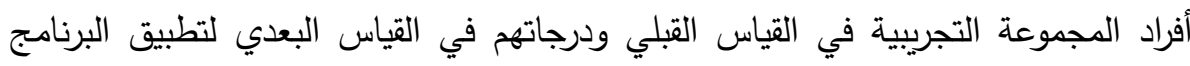

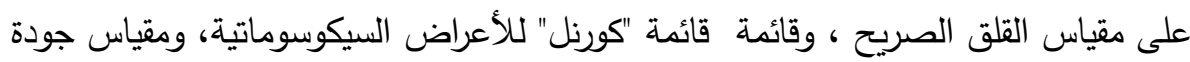

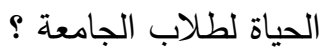
r - هل توجد فروق بين درجات طلاب وطالبات الجامعة ذوي الاضطرابات

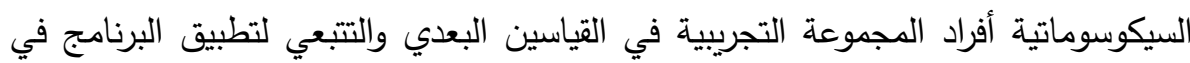
كل من مقياس القلق الصريح، وقائمة قائمة "كورنل" للأعراض السيكوسوماتية و ومقياس الفياس

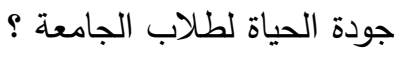

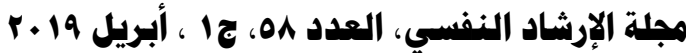




\section{هصطالمات البمث :}

يتاول البحث الحالي عددا" من المصطلحات الأساسية هي : ( البرنامج الارشادي العقلاني الانفعالي - القلق - جودة الحياة - طلاب الجامعة ذوي الاضطرابات السيكوسوماتية ) وسيتم تعريفه تعريفا" اجرائيا" مناسبا" مما يمكن من دراسة موضوع البحث

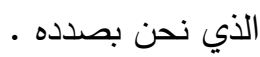

ا- البرنامج الارشادي العقلاني الانفعالي : Rational Emotive Guidance program

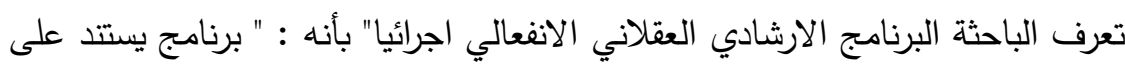

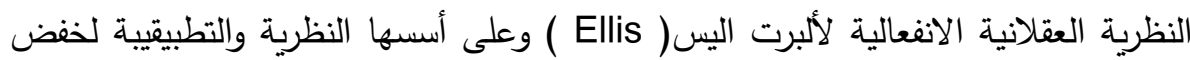

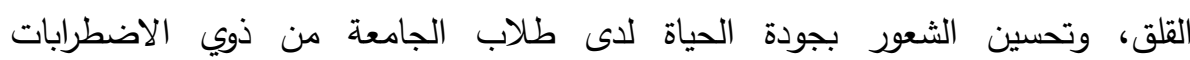

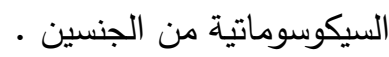

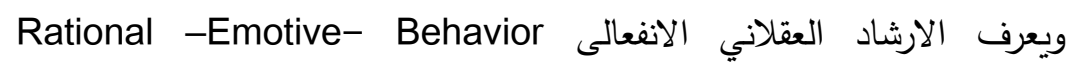
بأنه نظرية في الثخصية وأسلوب في الارشاد النفسي · وضعانع Counseling

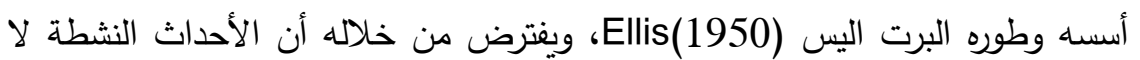

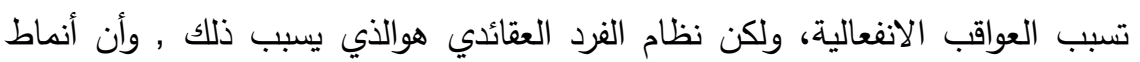
التفكير الخاطئة هي التي تؤدي لحدوث السلوك المضطرب ويهدف الارشاد العقلاني الانفعالي إلى التعديل المعرفي للاعتقادات اللاعقلانية والخاذلة للذات والإقلال من لتوديل الالحاحات Musts والينبغيات Shoulds التي يعتنقها العميل ويؤمن بها, وتعليمه

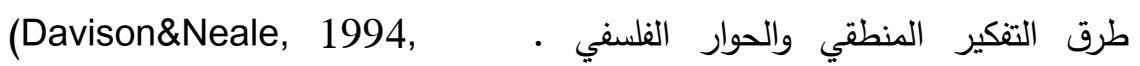
p:609;Corsini\&Auerbach,1996,p:767)

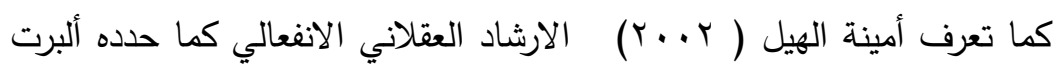
اليس Ellis بأنه يستتد على الافتراض الأساسي للارشاد العقلاني الانفعالي الخاص بأن الأن

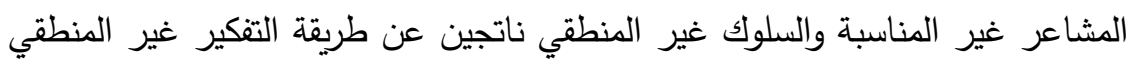

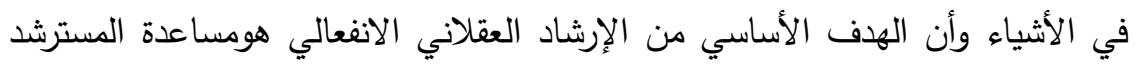

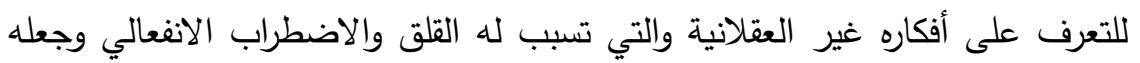

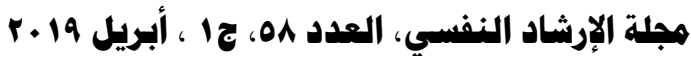




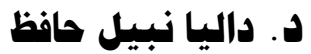

يعترض عليها واقناعه بالابتعاد عنها وتعديلها ثم تثجيعه على تبني فلسفة جديدة في

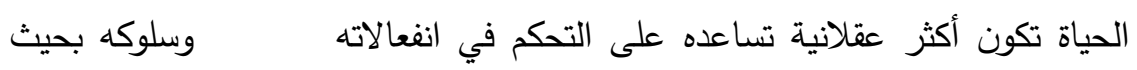

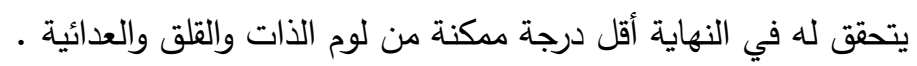

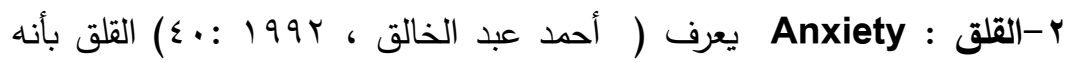

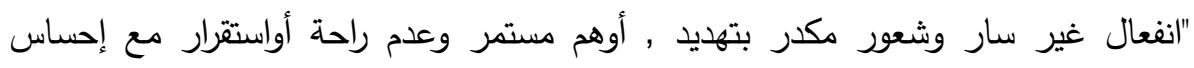

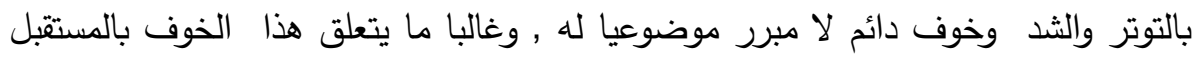

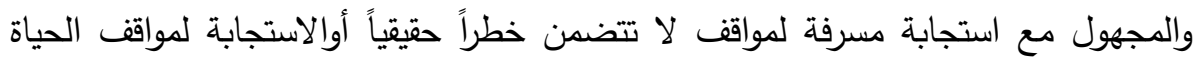

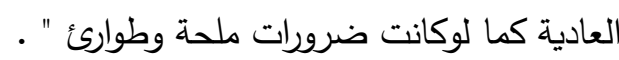

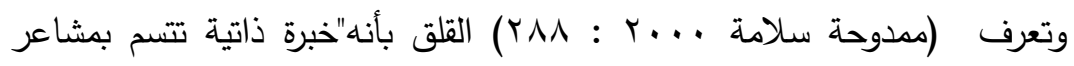
التوجس وتوقع المصائب والثر كالموت أوالمرض أوالحوادث كما يتميز أيضا بالثعور

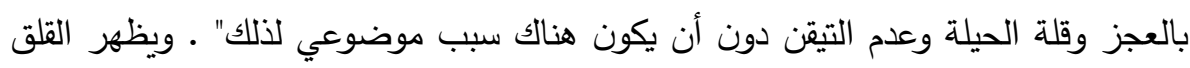

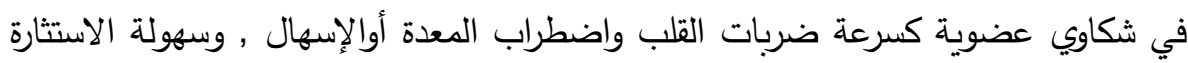

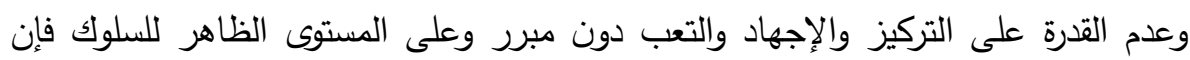

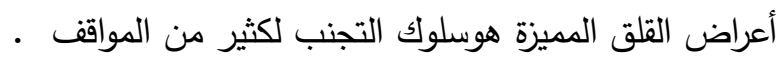
وتتبنى الباحثة هذا التعريف حيث يتماشى مع الأداة الدستخدمة في الدراسة الحالية.

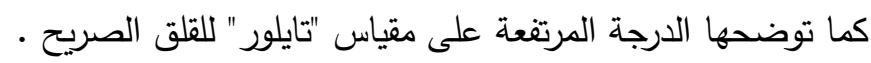
Quality of life : جودة الحياة عرف شالوك ( Schalock , 2002 جودة الحياة بإعتبارها مفهوم يتضمن

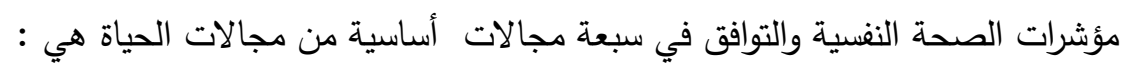

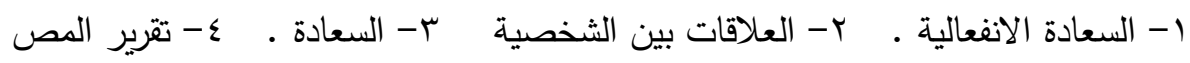

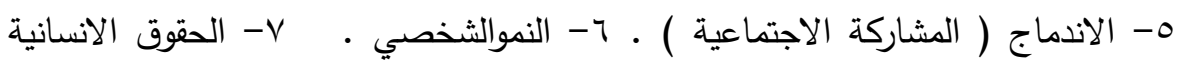
والقانونية .

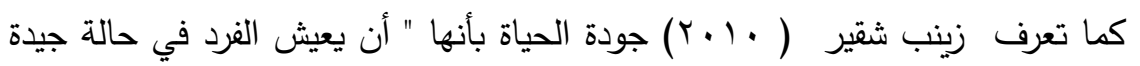

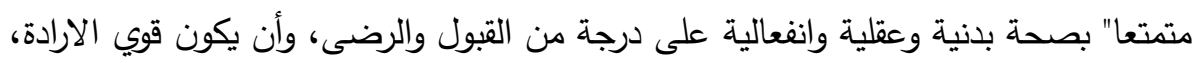

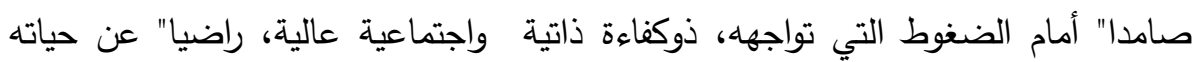
الأسرية والمهنية والمجتمعية، محققا" لحاجاته وطموحاته، واثقا" في نفسه، غير الفير مغرور

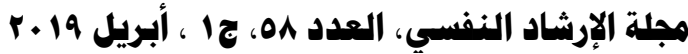


ومقدرا" لذاته بما يجعله يعيش شعور السعادة، وبما يشجعه ويدفعه لأن يكون متفائلا"

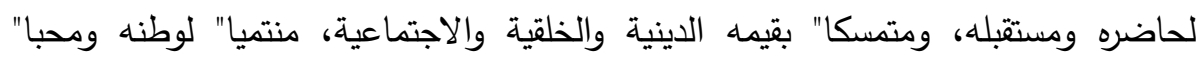
للخير، ومدافعا" عن حقوقه وحقوق الغير، ومتطلعا" للمستقبل " .

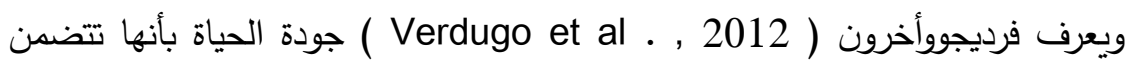
أربعة مبادىء هي " جودة الحياة مع الآخرين، القدرة على تلبية احتياجات الثخص، وتحقيق

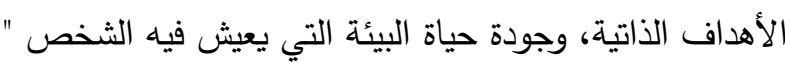

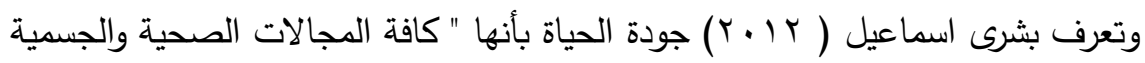

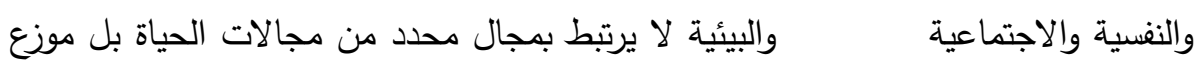
على أربعة أبعاد هي ( الصحة الجسمية، الصحة النفسية، العلاقات الاجتماعية، البيئة ) .

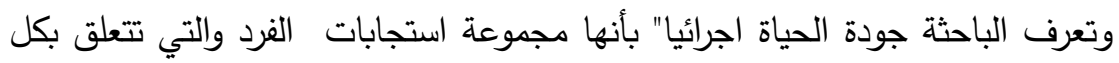
من جودة الحياة الاجتماعية، وجودة الحياة المادية، وجودة الحياة الوجدانية، وجودة الحهاه التحصيل الدراسي، والشعور بالرضا عن الحياة حيث يتماشى هذا التعريف مع الأداه المستخدمة في الدراسة الحالية، كما توضحها الدرجة المرتفعة على مقياس جودة الحياة

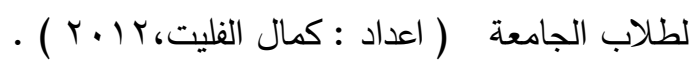
ـ University Students of : طلاب الجامعة ذوي الاضطرابات السيكوسوماتية psychosomatic disorders وهم مجموعة طلاب الجامعة الذين يعانون من الاضطرابات السيكوسوماتية من الجنسين،

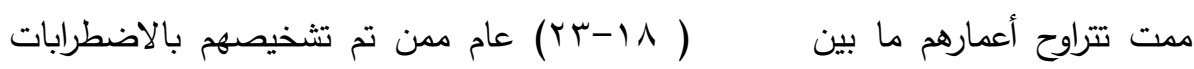

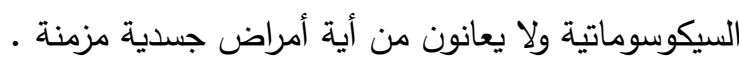
وينبغي علينا في هذا الجزء أن نعرض لتعريف الاضطرابهات الترات السيكوسوماتية كالتالي :

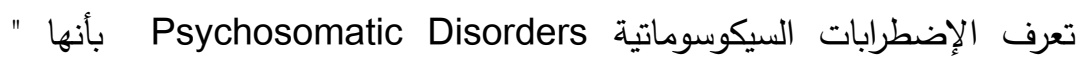
الاضطرابات الجسمية المألوفة للأطباء والتي يحدث بهات تلف في جزونه من أجزاء الجسم

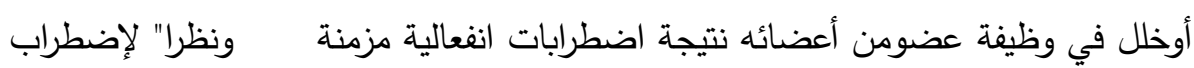
حياة المريض والتي لا يفلح العلاج الطويل وحده في شفائها شفاء تاما" لإستمرار الضغط فئه فئه الانفعالي وعدم علاج أسبابه إلى جانب العلاج الجسمي " ( محمود ابوالنيل، ـ99 19 1، 7 (1) 


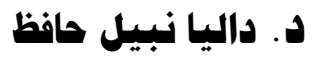

وتتبنى الباحثة هذا التعريف حيث يتماشى مع الأداه المستخدمة في الدراسة الحالية، كما

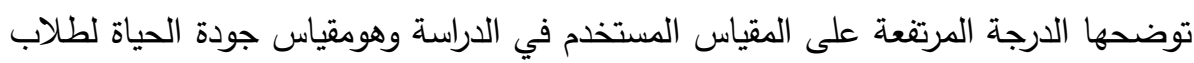

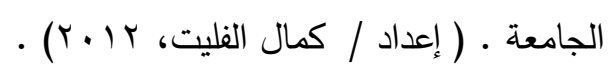

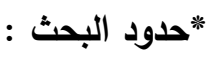

تقع حدود البحث الحالي في الآتي : أ-الحدود المكانية : تم اجراء هذا البحث على عينة من طلاب الجامعة من الجنسين من المصابين بالاضطرابات السيكوسوماتية ممن يترددون

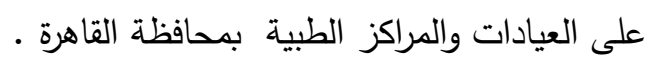

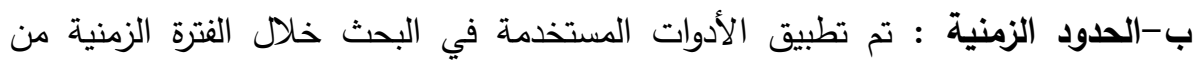

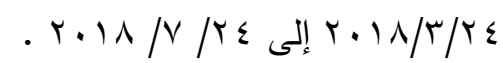

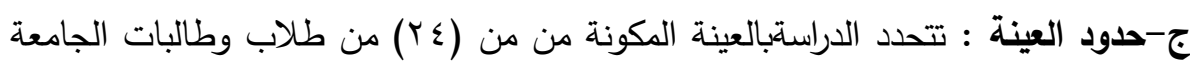

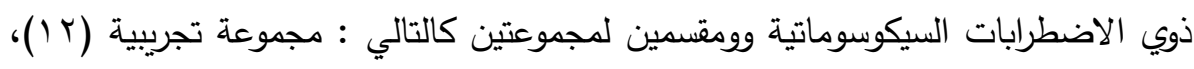

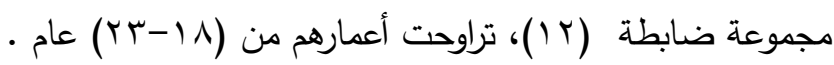
د- حدود الأدوات : تتحدد الدراسة الحالية بالأدوات المستخدمة وهي : ترام : قائمة كورنل

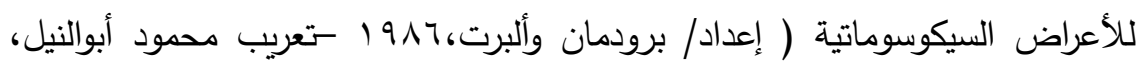

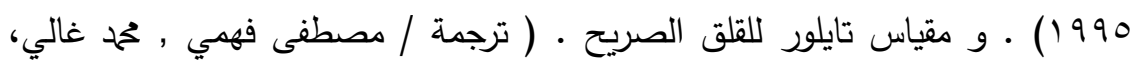

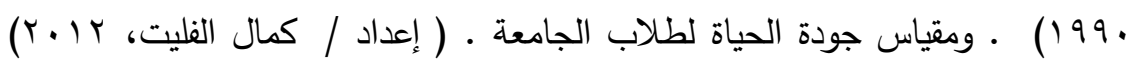

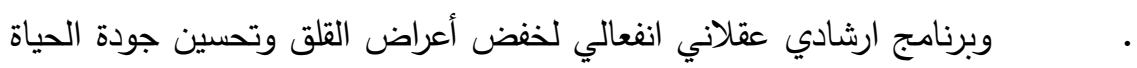

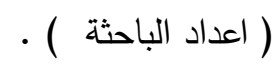

$$
\begin{aligned}
& \text { الإطار النظري : } \\
& \text { يتضمن الإطار النظري للبحث أربعة محاور أساسية كالتالي : }
\end{aligned}
$$

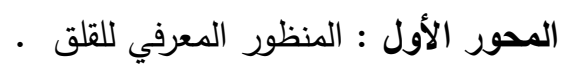

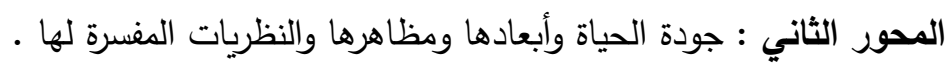

$$
\begin{aligned}
& \text { المحور الثالث : الارشاد العقلاني الانغعالي الثردان }
\end{aligned}
$$


"أولا" المحور الأول : القلق من المنظور المعرفى :

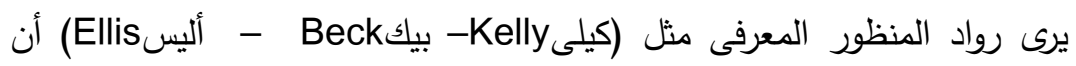

القلق Anxiety هواضطراب انفعالى يرتبط باضطراب التكوين المعرفي للفرد الذي يشمل

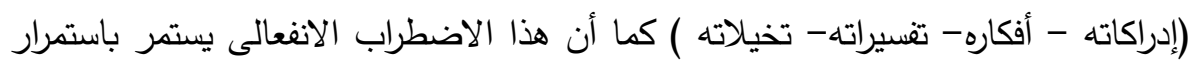

$$
\text { تبني الفرد لأفكار ومعارف معينة . }
$$

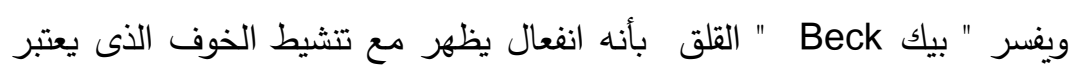

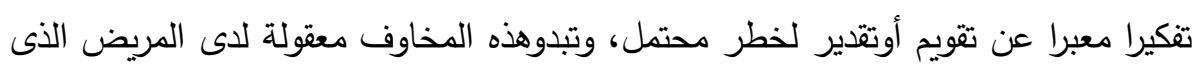

$$
\begin{aligned}
& \text { تسود تفكيره موضوعات الخطر والتى قد تعبر عن نفسها فيما يلى }
\end{aligned}
$$

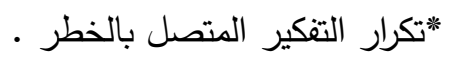

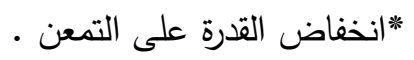

$$
\begin{aligned}
& \text { *التفكير غير المتعقل فى الأفكار المخيفة وعدم تقويمها بموضوعية . }
\end{aligned}
$$

*تعميم المثيرات المحدثة للقلق إلى الحد الذى يجعل أى مثير أوموقف قد يدرك على أنى أنه مهدد فانتباه المريض يبدوأنه مرتبط بتصور أومفهوم الخطر ويسبب تثبت أوتوقف الف التبت التباه

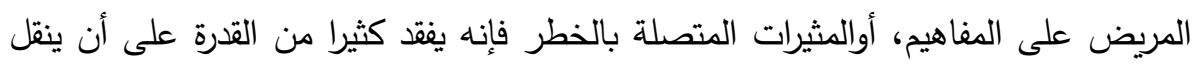

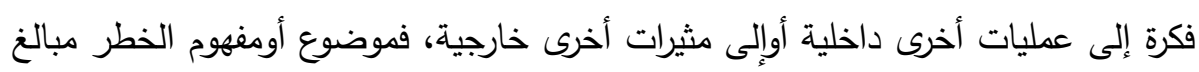

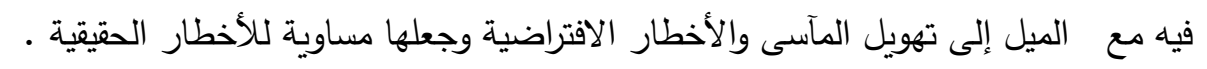

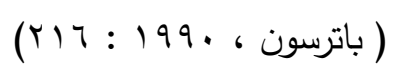

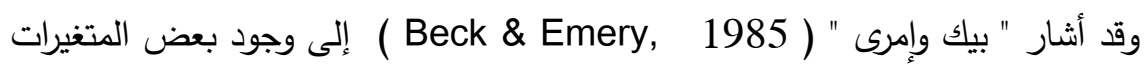
المعرفية التى تسهم فى حدوث واستمرار القلق، حيث يرتبط القلق بمبالغة الفرد فى تقدير

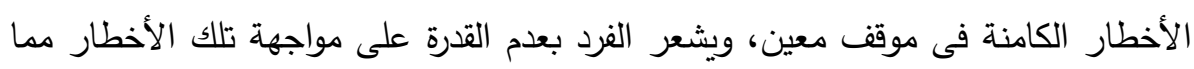

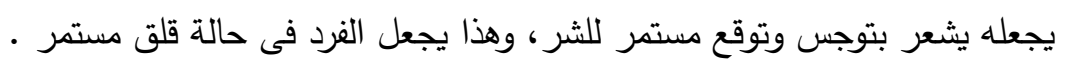

(Greenberg , 1989 , pp : 25-26 )

كما يؤكد كيلى Kelley على أن الاضطراب الانفعالى ينشأ من التوقعات اللامعقولة،

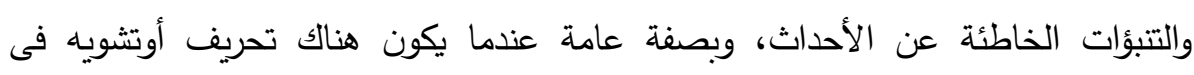
مضمون أهداف وتوقعات الفرد الثخصية أوفى فلسفته.

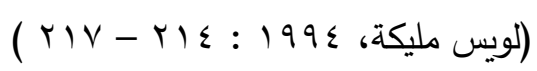

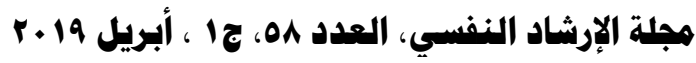


كما أشار كلارك وآخرون Clark et al.,1989 ) أن خبرات الطفولة المؤلمة والتي تتسم بالشعور بعدم الأمن والتهديد تجعل الفرد يكون صيغة سلبية إجمالية عن الذات Negative self - Schema التي تتضمن توقعا للمخاطر والتهديد, مما يجعله يحرف كل الخبرات التي يمر بها في التهر في اتجاه

$$
\text { التوقع المستمر (عماد محمد إبراهيم, 1990) }
$$

ويذكر وليام وآخرون(Williams et al.,1997) أن المصابين بالقلق عادة ما

يكون لديهم تصور عن أنسسهم بأنهم في حالة خطر دائم ويمرون بمخاطر مستمرة يكونون

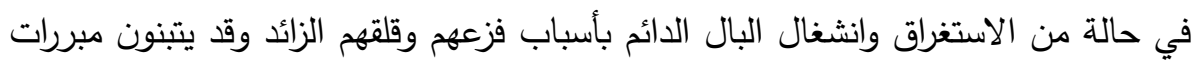

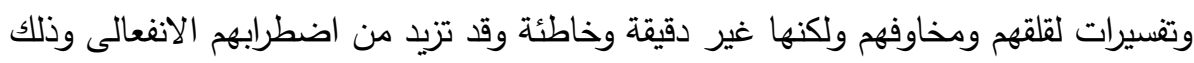

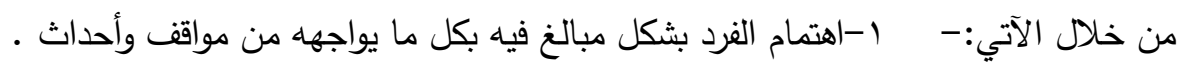

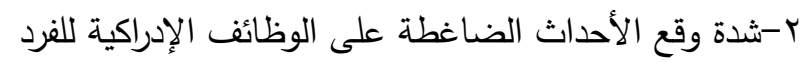

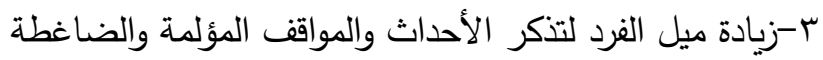

(Williams et al.,1997,PP:7-8)

وبشكل أكثر تفصيلا يذكر " ألبرت اليس Ellis أن الانفعالات غير الملائمة مثل فئل

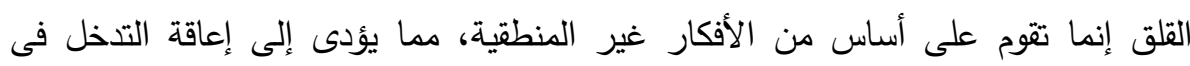

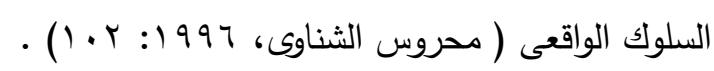

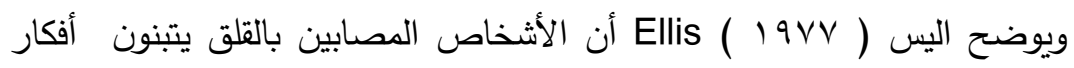

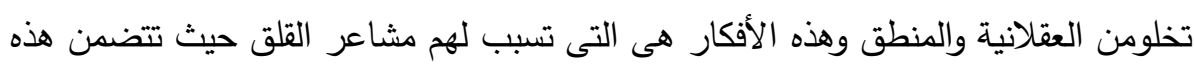

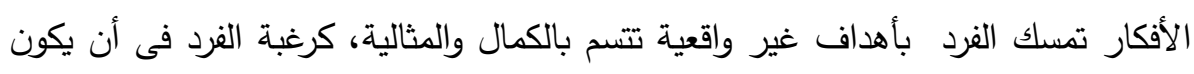

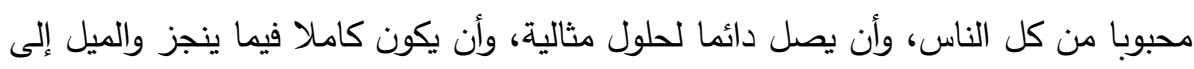

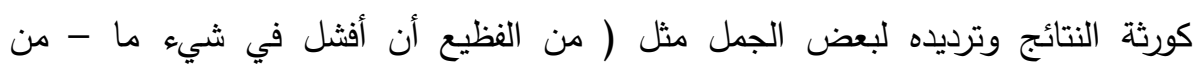

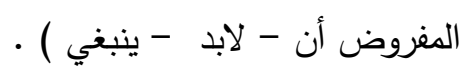

(Davison \& Neale, $1994, p:$ : 170)

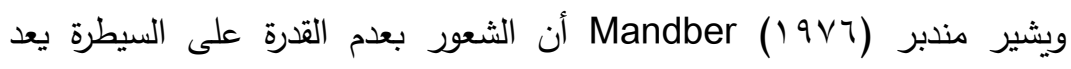

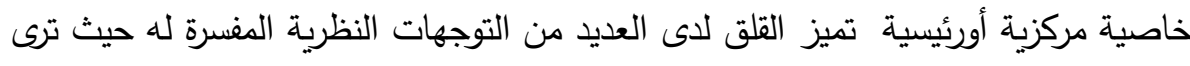

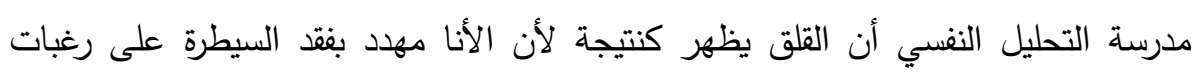

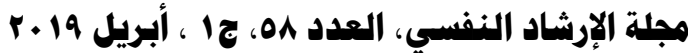


الهوكما تظهر نظرية التعلم أن القلق يحدث حينما يواجه الفرد مواقف مؤلمة تفوق قدرته على

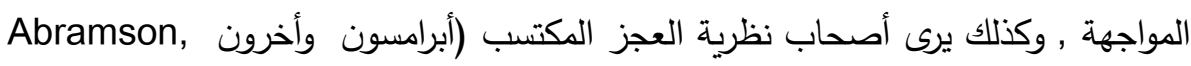
(et al.,1978 أن الفرد يشعر بالقلق والبؤس حينما يعتقد في عدم قدرته على التحكم في

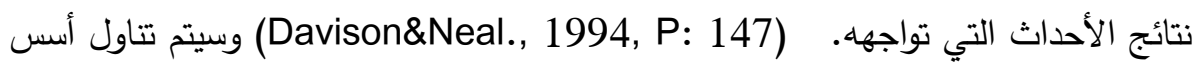
العلاج العقلانى - الانفعالى ودوره فى علاج القلق بشكل أكثر تفصيلا فى الفصل الخاص بالعلاجات المعرفية للقلق والاكتئاب.

وقد قدم كل من بيك وامري (Beck\&Emery,1988) نموذجهما للقلق, ويعتبران في هذا النموذج أن توقع المخاطر أوالشر هوالعرض الأساسي المميز للقلق, حيث

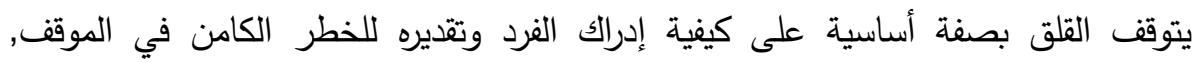
فالتشويه المعرفي في اتجاه التوقع المستمر للخطر الكامن في الموقف , يجعل الفرد في حالة

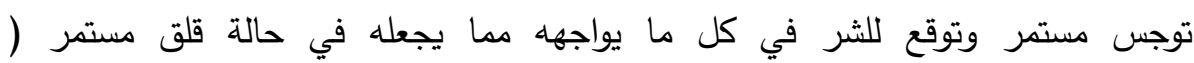

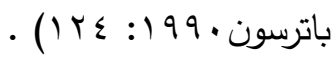
ولأن التفكير يحدد الانفعال فبمجرد أن يفحص العميل خواطره السلبية التلقائية ويتعرف عليها فإن أعراض الاكتئاب تبدوله ذات معنى ,أي انه يدرك العلاقة بين ما لايه من أفكار

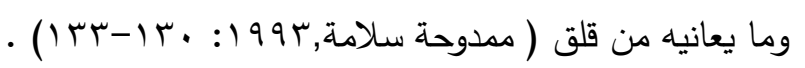

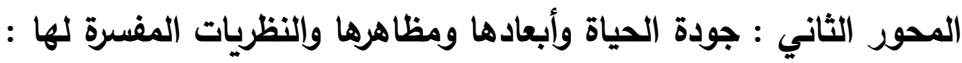
يندرج مفهوم جودة الحياة تحت مظلة علم النفس الايجابي ويتضمن الثعور الايجابي نحوجوانب الحياة المختلفة سواء الجوانب الاجتماعية اوالجوانب الجسدية

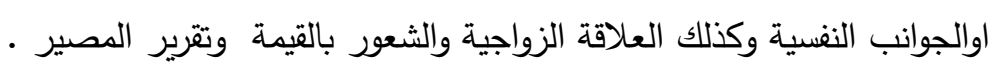

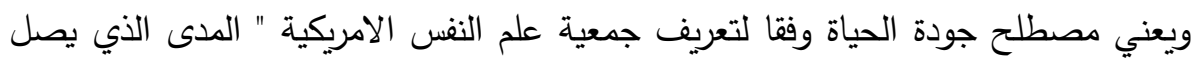

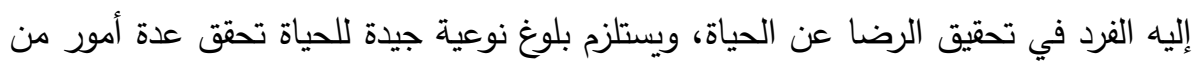

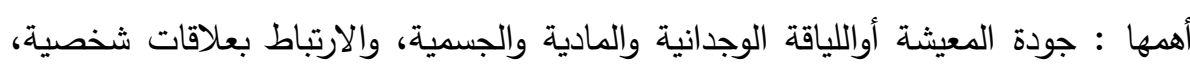

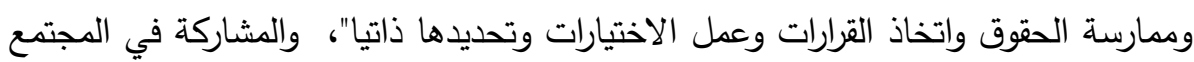

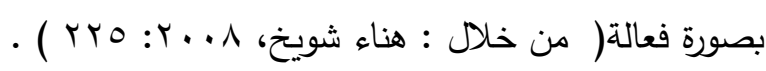

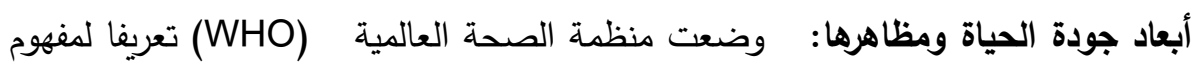
جودة الحياة بإعتباره: ادراك الفرد لوضعه المعيشي في سياق أنظمة وقيم المجتمع الذي

\section{هبلة الإرشاد النفسي، العدد 01، ع1 ، أبريل 19 r r}




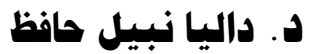

يعيش فيه وعلاقة هذا الادراك بأهدافه وتوقعاته ومستويات اهتمامه ـ كما حددت منظمة الصحة العالمية ستة أبعاد لجودة الحياة هي : بالداك

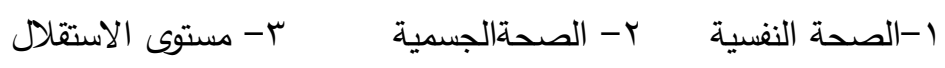

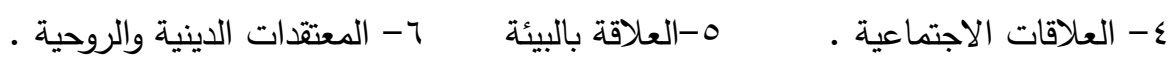

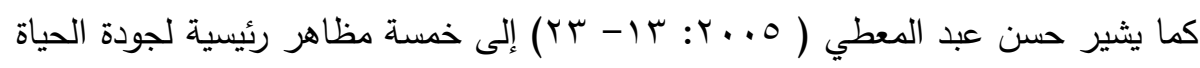
كما يلي : إنير

ا-العوامل المادية والموضوعية والتعبير عن حسن الحال وتثير إلى الخدمات التي يوفرها

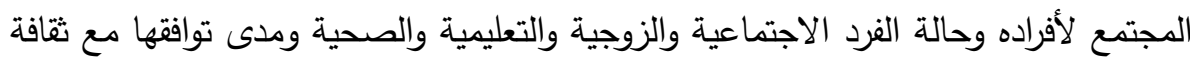

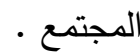
r- اشباع الحاجات والرضا عن الحياة وتشير إلى أن جودة الحياة ترتبط بمدى اشباع الفرد

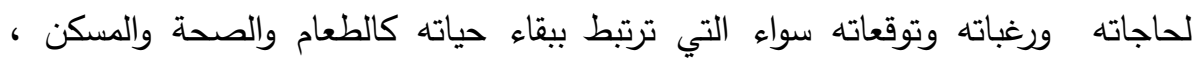

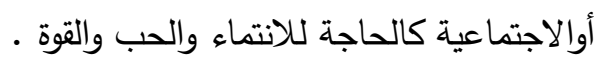
r-ادراك الفرد القوى والمتضمنات الحياتية واحساسه بمعنى الحياة : ويشير إلى استخدام

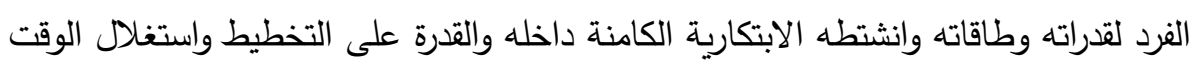
من أجل تتمية علاقاته الاجتماعية،وكذلك شعور الفرد بقيمته ومدى أهميته في المجتمع .

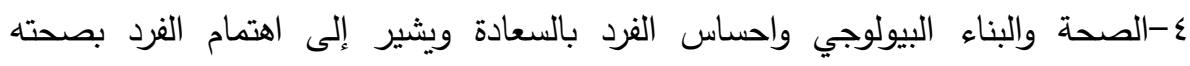

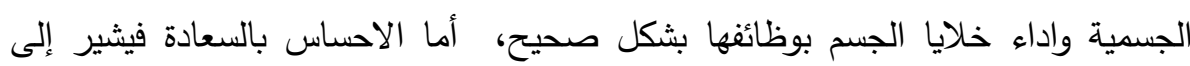

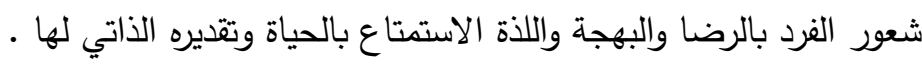

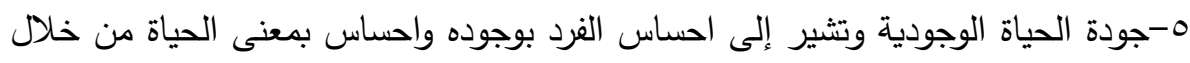

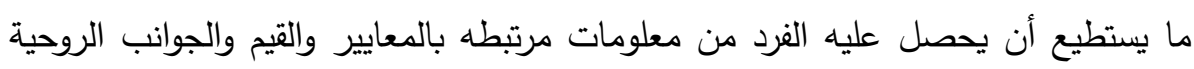

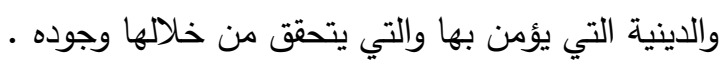
النظريات المفسرة لجودة الحياة : تعددت النظريات المفسرة لمفهوم جودة الحياة وسنعرض لبعضيها كما يلي:

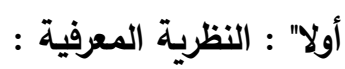

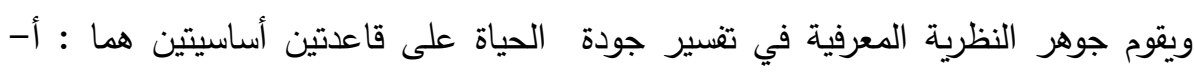
تتوقف درجة شعور الفرد بجودة الحياة على كيفية إدراكه لجوانب الحياة الدختلفة .

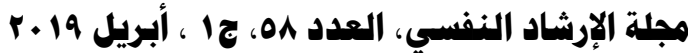


ب- كنتيجة للإختلاف بين الأفراد في الإدراك لجوانب الحياه المختلفة، فإن العوامل الذاتية

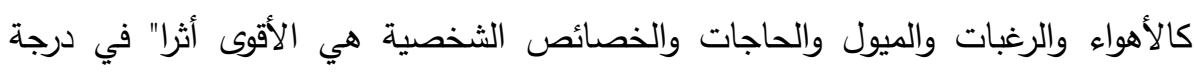

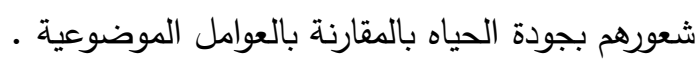

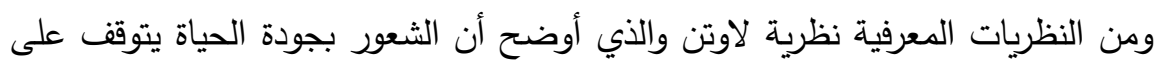
طبيعة البيئة وذلك من خلال كل من : النطريات

1- الظرف المكاني ويقصد به أن ادراك الفرد لجودة الحياة يتأثر بطبيعة المكان والبيئة

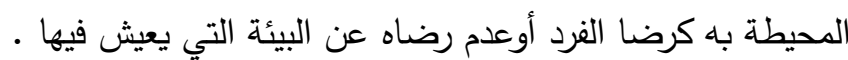
r-الظرف الزماني : ويقصد به أن درجة إدراك الفرد لجودة الحياة يتأثر فكلما تقدم به العمر لئه كلما كان أكثر شعورا" بالسيطرة على ظروف حياته وأكثر شعورا" بجودة الحياة .

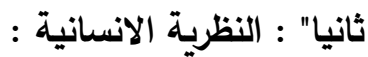

ويرى المنظور الانساني مفهوم جودة الحياة يرتبط بمفهوم الذات Self Concept لابد وأن يرتبط بعنصرين أساسيين حيث يتأثر الشعور بجودة الحياة على التفاعل المتبادل بينهما ئبطان

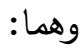
ا-وجود كائن حي ملائم أي قادر على فهم ذاته وحل مشكلاته واتخاذ قراراته بنفسه ץ-وجود بيئة جيدة ومناسبة تهييء للفرد الظروف الملائمة لتتمية ذاته وحل مشكلاته

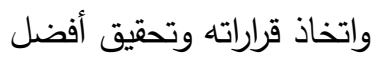

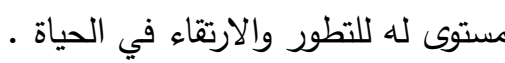
ثالثا" النظرية التكاملية : ويذهب المنظور التكاملي إلى أن مفهوم جودة الحياة يجمع بين عددا" من المفاهيم مثل

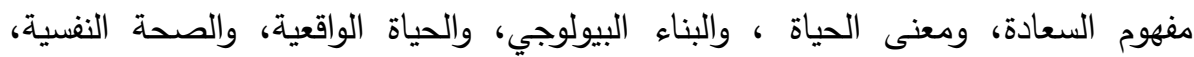
والاندماج الاجتماعي، واشباع الحاجات وذلك في إطار نظري تكاملي لتفسير جودة الحياة . ولقد طرح أندرسون (Anderson, 2003 ) من خلال منظوره التكاملي شرحا" تكامليا"

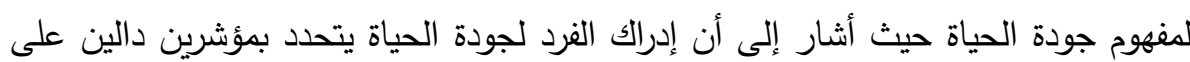

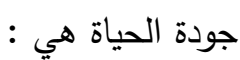
1- شعور الفرد بالرضا من خلال وضعه لأهداف واقعية قادر على تحقيقها، وأن يسعى لتغيير ما حوله ليتلائم مع أهدافه . لئل

\section{هجلة الإرشاد النفسي، العدد 01، ج1 ، أبريل 19 r r}




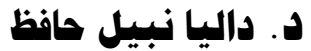

r- استغلال الفرد لقدراته وطاقاته في أنشطة إبداعية، وعلاقات اجتماعية مستقرة، وعلاقات

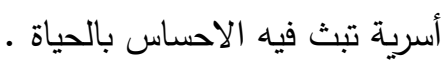

Rational Emotive Counsling : ثالثا" : الارشاد العقلانى - الانفعالى الإنى يعرف الارشاد العقلاني الانفعالى لاليس Ellis بأنه : نظرية فى الثخصية وأسلوب

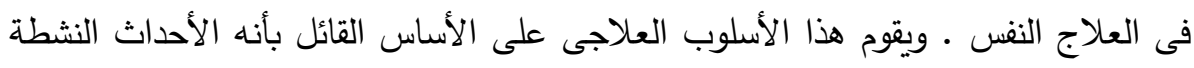

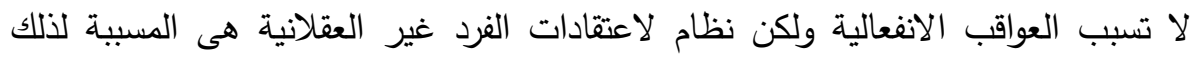

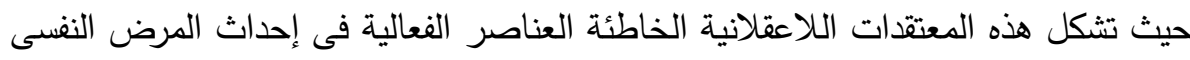

( Nielsen et al. , 2000) ويركز إليس Ellis من خلا نظريته فى العلاج العقلانى - الانغعالى على أهية العلاقة

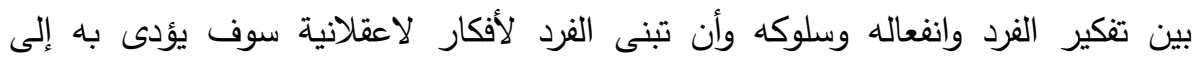

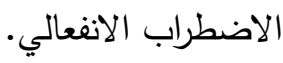
ويذكر دوليفر(Dolliver,1977,P:57) أن من أهم الأفكار الرئيسية التى يقوم عليها المنهج العقلانى - الانفعالى هى: مالا تستطيع تغيره يجب عليك النيك أن تتقبله، لأن الحقيقة

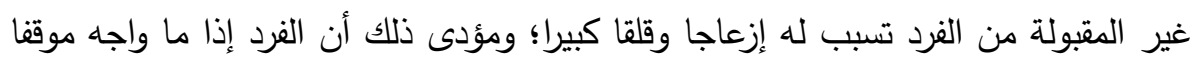

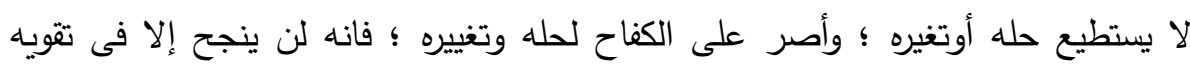

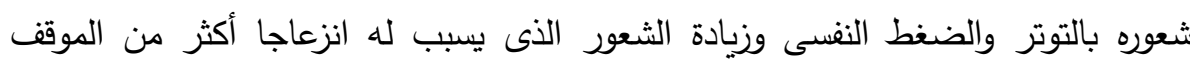
الضاغط.

ويرى اليس ( 19A9Ellis ) أن المنهج العقلانى الانفعالى يعتبر ذوفاعلية فى التنخل

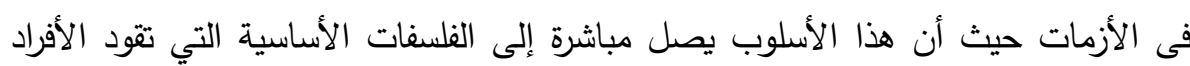

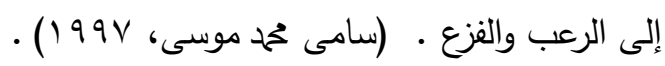
ويذكر اليس Ellis ( ع 199) من خلال هذه النظرية أن نظام الفرد وتفسيره للأحداث التى يمر بها هى المسئولة عن المشاعر الهازمة للاتات والمسببة لاضطرابه الانفعالى وليس

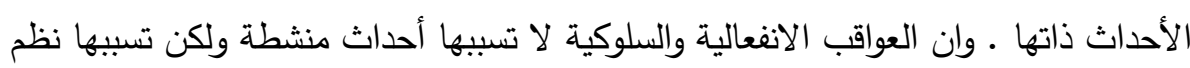

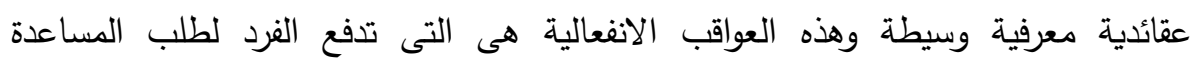
العلاجية. (Nielsen et al., 2000. P : 21) 


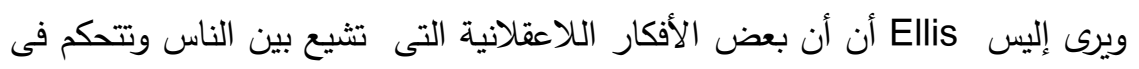

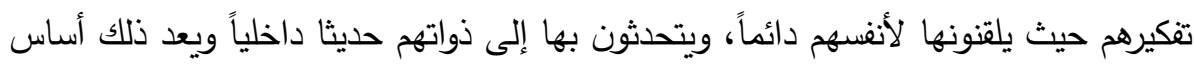
Shoulds التفكير عندهم وعادة ما تتشكل هذه القضايا والأفكار على هيئة (الينبغيات)

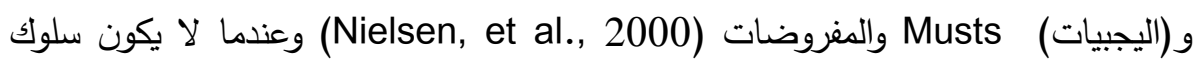
الفرد على هذا المستوى المثالى (وهوما يحدث عادة) فإن الفرد يشعر بالعجز ونقص الثقة، والى

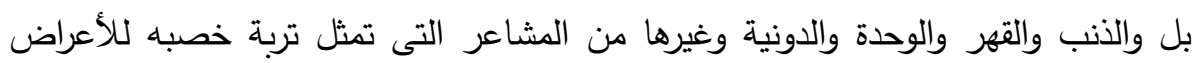

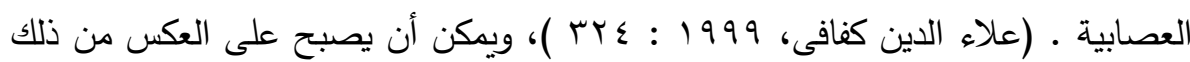

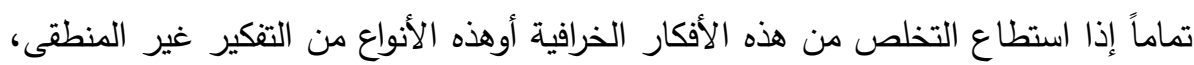

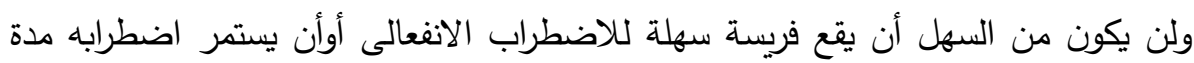

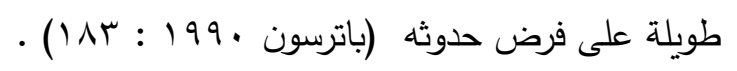
ويرى اليس Ellis أنه إذا استمر الفرد فى التمسك بهذه الأفكار اللاعقلانية فقد يؤدى هذا إلى الشعور الدائم بالنقص وعدم الكفاية والخوف المستمر من الفشل، حيث يعتقد الفرد بأن

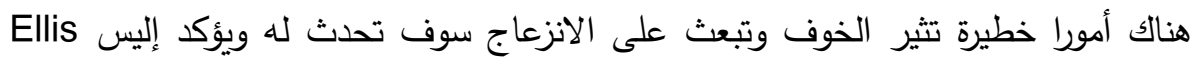

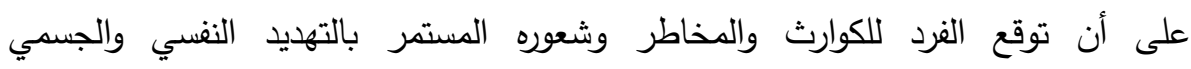
والاجتماعى هوالعرض الرئيس لعصاب القلق. Ellis,1990) فالقلق يرتبط أساسا بالمبالغة

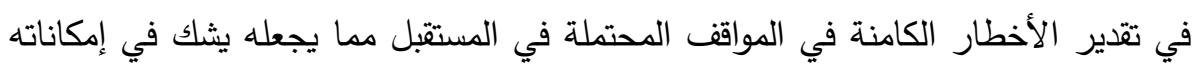

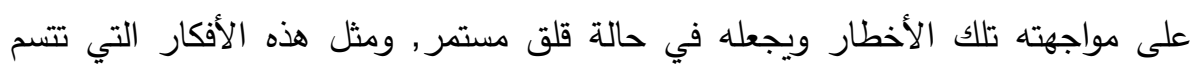

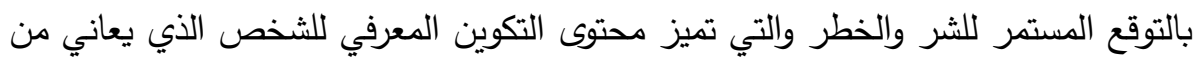

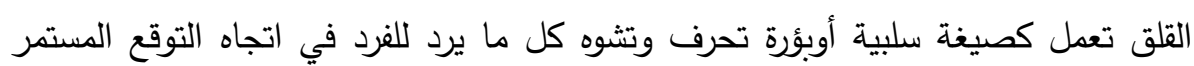

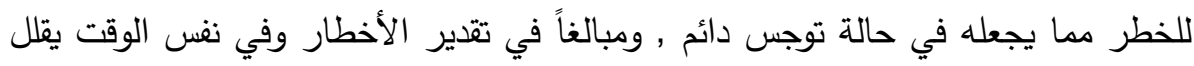

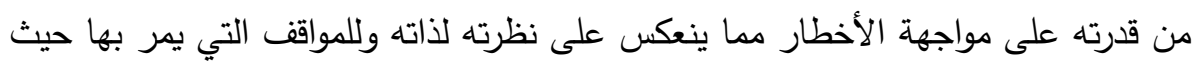

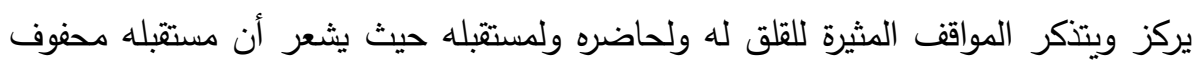

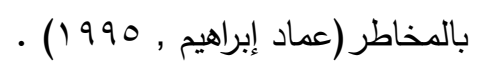

ويشير دريدن ودجيوسب (Dryden \& Digiuseppe ,1990,p:10) إلى أن العلاج العقلانى - الانفعالى يؤكد على أنه بالإككان تغيير التفكير غير العقلانى والمعتقدات

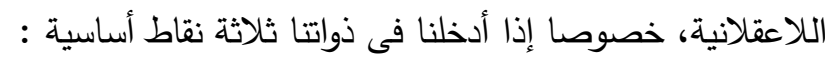

\section{هبلة الإرشاد النفسي، العدد 01، ع1 ، أبريل 19 r r}


( (1) أن نظم معتقداتتا تجاه الأحداث المنشطة والخبرات هى التى تسبب سلوكياتا وانفعالاتتا

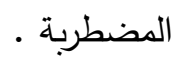

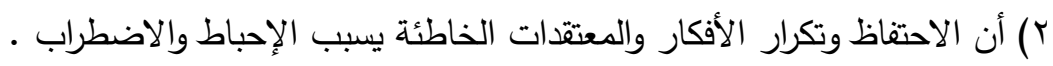

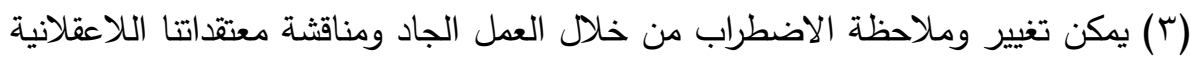

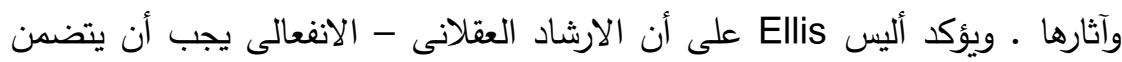

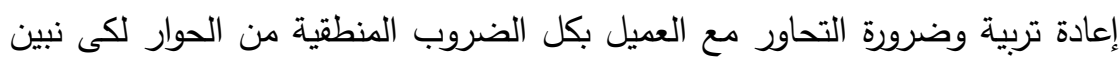

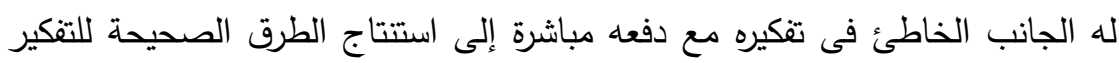
وتطبيقها. أهداف الارشاد العقلانى - الانفعالى :

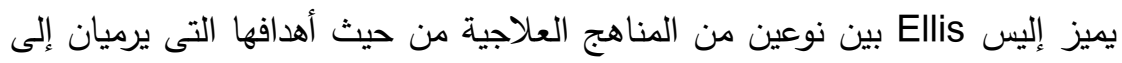
تحقيقها:

الأول : هوالمنهج العقلانى - الانفعالى السلوكى العام، وهونغس الدنهج السلوكى المعرفى الذى يهدف إلى تعليم الأفراد السلوكيات العقلانية الملائمة.

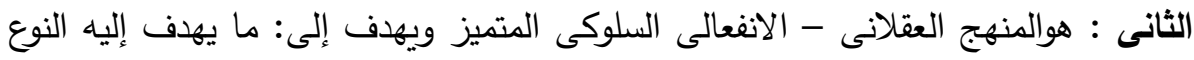

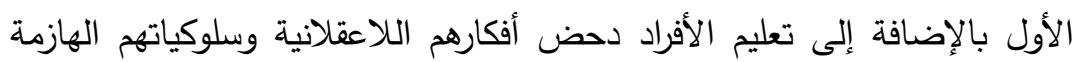

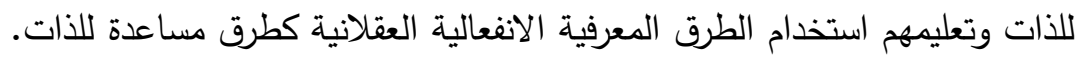

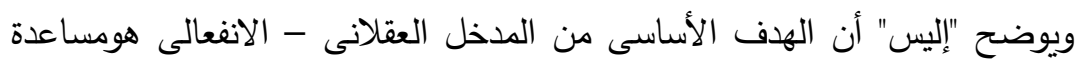

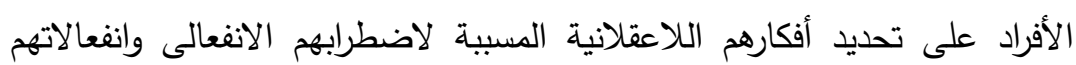

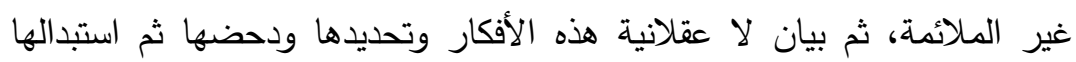

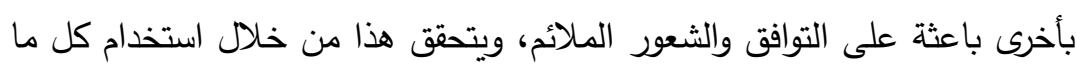

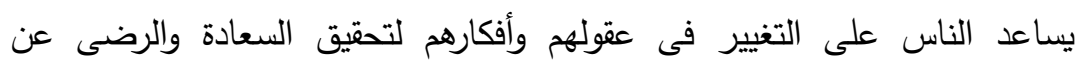
الحياة. (Nielsen et al., 2000) . كما تذكر مددوحة سلامة (9100) أن الاسلوب العقلانى - الانفعالى يهدف إلى التقليل

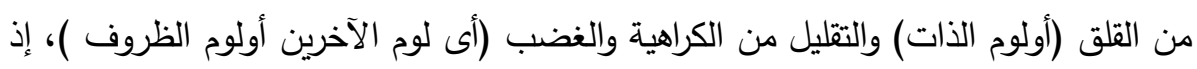

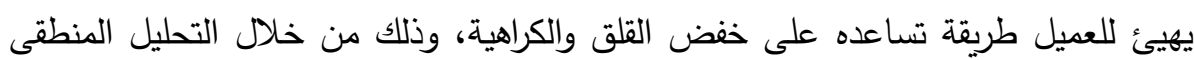

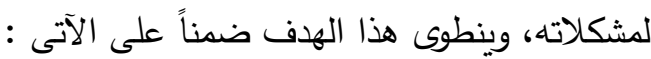

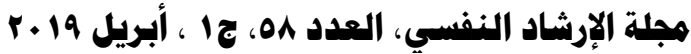




$$
\begin{aligned}
& \text { 1- الاهتمام بالذات والاعتراف بحقوق الآخرين . ب-الاستقلال والمسئولية . }
\end{aligned}
$$

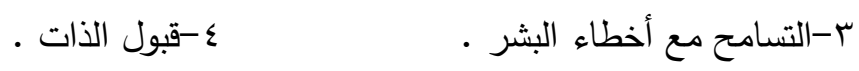

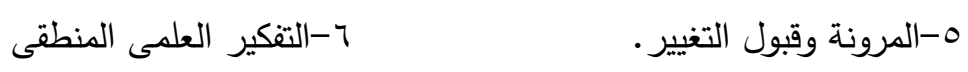

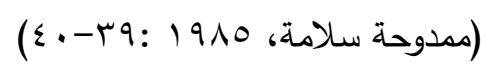

ويرى "إليس" Ellis (99v) (1990) أنه لكى تتحقق أهداف الارشاد العقلانى - الانفعالى ينبغى

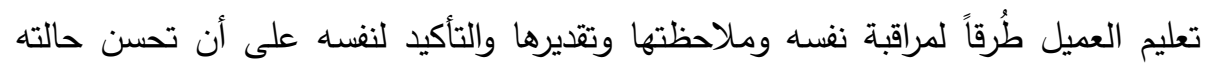
سوف يستمر، كما أوضح Ellis أن هناك هدفاً آخر هاماً ولكن على ولى المدى الطويل

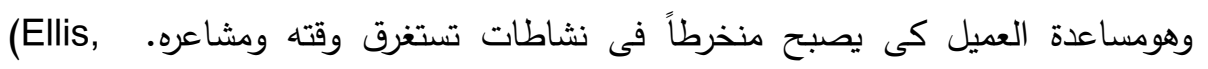

1997, P: 161)

*العلاقة بين المرشد والعميل في الارشاد العقلاني الانفعالي : يشير كل من (Druden\& Digiuseppe, 1990) إلى أن من أهم أصول تكوين العلاقة

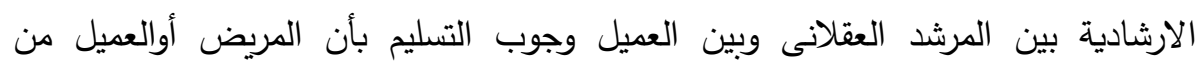
المنطقى أن تكون لديه صعوبات فى التعبير عن تلك المعتقدات أوالتعرف عليها، أوالتتازل

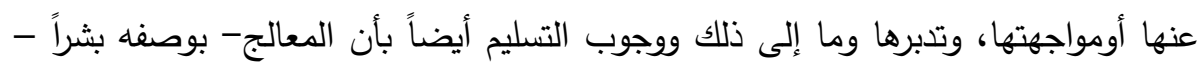
قد تكون لديه صعوبات فى البوح بما لديه من معتقدات غير لائقة، أومحاولة إخفائها،

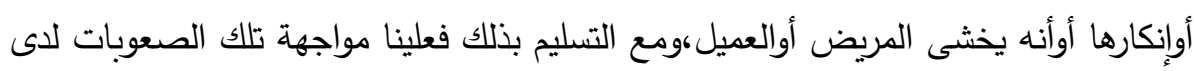
الطرفين حتى تستقيم العلاقة العلاجية.

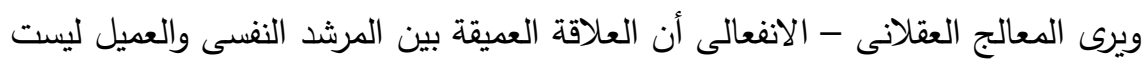

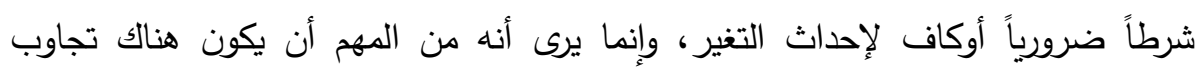
Rapport

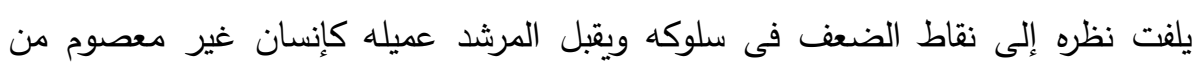
الخطأ تُغتفر لله أخطائه دون أن يكون هناك بالضرورة علاقة دفء شخصية بينهما، كذلك للمرشد أن يناقش عميله مناقثات تهدف إلى تعليمه، كما يمكن أن يستخدم معه أساليب

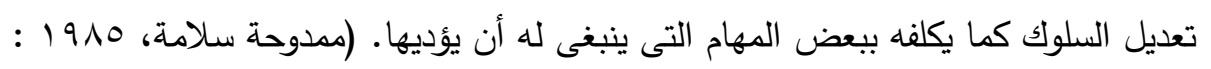


وتتضمن تلك العلاقة أن يتجه المرشد بالتدريج وبحرص نحوالتفكير غير العقلانى وغير

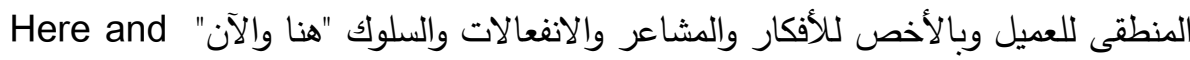

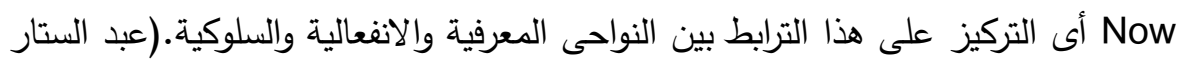

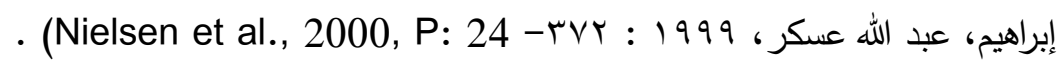
ويستخدم "إليس Ellis" أسلوب الحوار المركز على عميل "محورى" Focal فى اللحظة المعينة (•r دقيقة بالضبط لكل عميل) وقد يوجه أعضاء الجماعة رسائل مباشرة لهذا لهابل العميل وذلك للكشف عن الاعتقادات اللاعقلانية ومناقضتها ولتوجيه التعليمات إليه للاستمرار فى ذلك إلى أن يحدث التغير وبعد فترة منعاً للرجوع إلى عادات التفكير القديمة

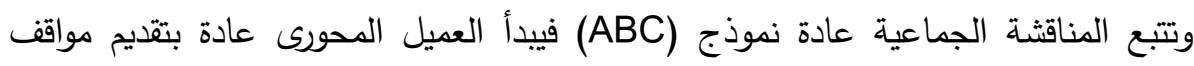

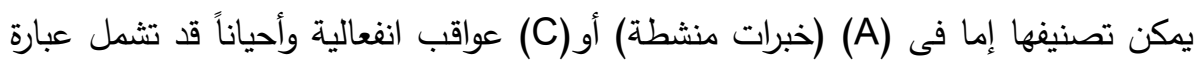
واحدة كلاً من (C,A) فى مشكلة معينة ويشجع المعالج على توجيه الأسئلة وعلى المناقشة حول (C,A)ذلك بقصد التوضيح ومساعدة العضوالذى يجد صعوبة فى التعبير عن خبراته

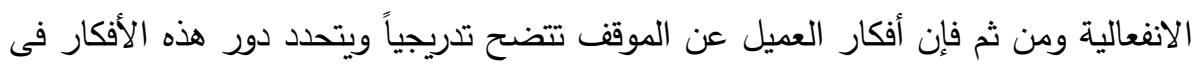

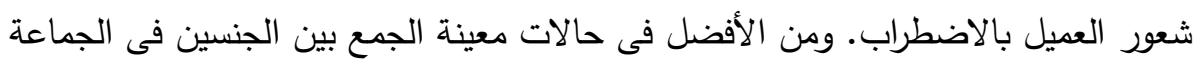

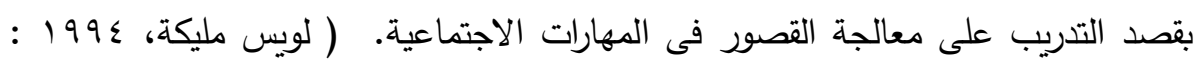

(r) $r-r)$.

فعالية الارشاد العقلاني الانفعالي في خفض القلق وتحسين جودة الحياة لذوي

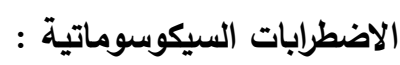
تتميز الاتجاهات الحديثة في دراسة علاقة الجسم بالعقل بتزايد اهتمام الباحثين بدور

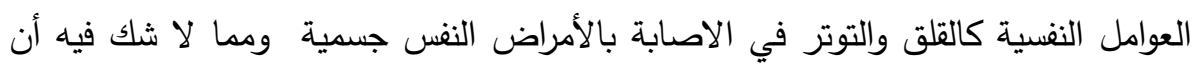

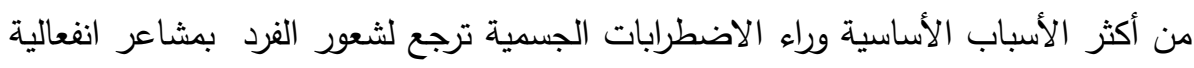

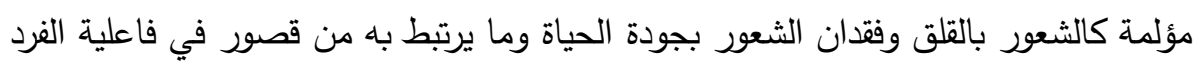

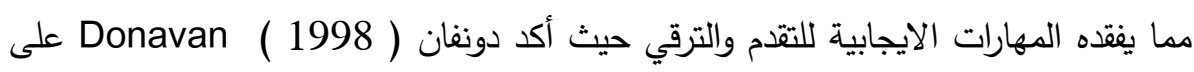
أن جودة الحياة تتضمن الوظائف الجسمية المتمثلة في انجاز الأنشطة الاجتماعية واليومية

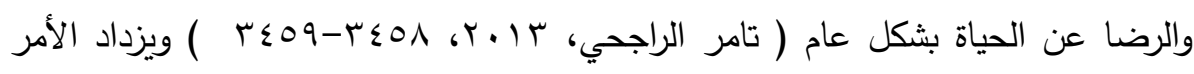

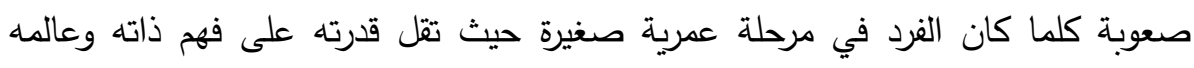

\section{هجلة الإرشاد النفسي، العدد 01، ج1 ، أبريل 19 r r}


وواقعه واكتشاف امكاناته واستعداداته مما يعيقه عن تحقيق أهدافه، وتعطل طاقاته وتمنعه من توظيف إمكاناته وتقلل من مستوى انجازه الأكاديمي وينعدم شعوره بجودة الحياة ورضاتهاه عنها، مما قد يؤثر سلبيا" على صحته النفسية والجسمية . وقد امتد اهتمام الباحثين بدور التنكير والمعارف في احداث الاضطراب الانفعالي والسلوكي والجسمي وفقا" لما يقوم عليه جوهر المنظور المعرفي من وجود علاقة وثيقة بين

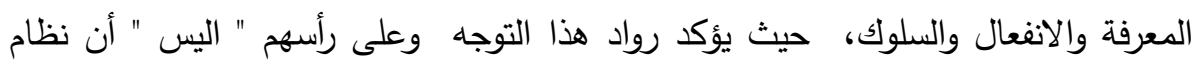

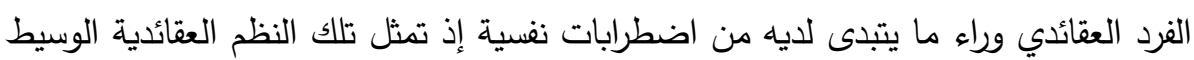

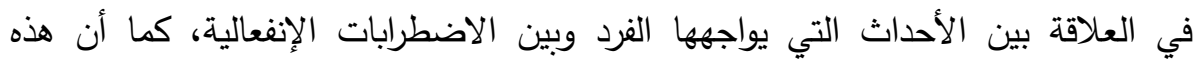

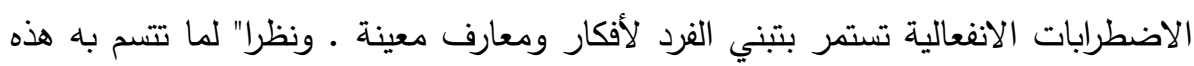

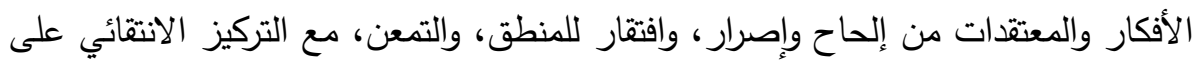

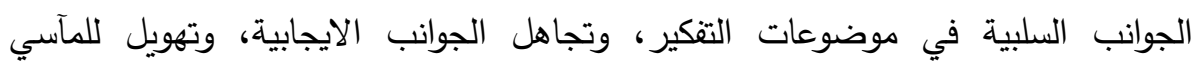

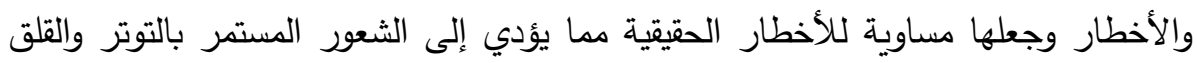
والإحباط، حيث تتاقض تلك المشاعر المؤلمة حالة التوافق النفسي والاجتماعي والدراسي ولتي والثعور بالرضا عن الذات والعالم والمستقبل وغيرها من المحددات الذي يتطلبها شعور الفرد بجودة الحياة والتي يعبر عنها لدى البعض من خلال تلف بعض أعضاء الجسم والاصابة بالاضطرابات السيكوسوماتية، ومن ثم فإن المعاناه من القلق وانخفاض مستوى جودة الحياة

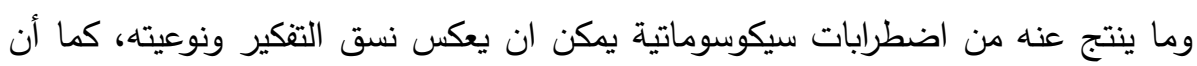

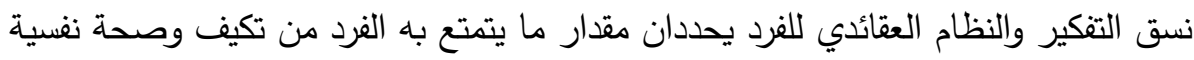

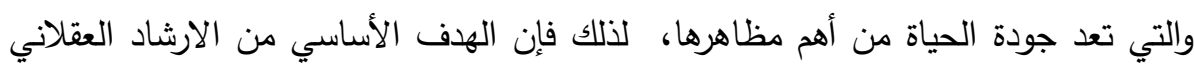

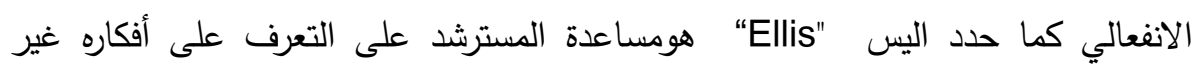
العقلانية وبدورها في احداث ما يعاني من قلق واضطراب نفسي وجسمي وتدريبه على هلى تفنيدها ودحضها وتعديلها وتبني فلسفة جديدة في التفكير والتعامل مع أحداث الحياة تكون أكثر عقلانية. ومن هنا تتضح أهمية البحث في تقصي وندي مدى فاعلية برنامج ارشادي عقلاني وانفعالي في خفض القلق وتحسين جودة الحياة لطلاب الجامعة ذوي الاضطرابات 


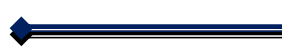

د. داليا نبيل حافظ

الدراسات السابقة :

تتبلور الدراسات السابقة لهذه الدراسة في ثلاث محاور أساسية كالتالي: أولا" : دراسات تتاولت جودة الحياة وعلاقتها بالقلق والاضطرابات السيكوسوماتية لاى عينات

مختلفة .

ثانيا" : دراسات تتاولت جودة الحياة لدى طلاب الجامعة وعلاقتها بمتغيرات أخرى .

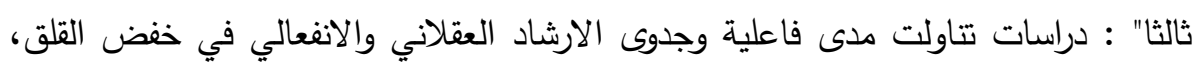

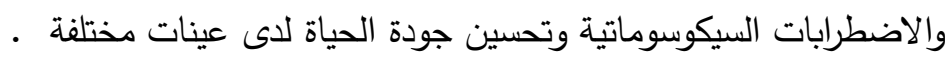

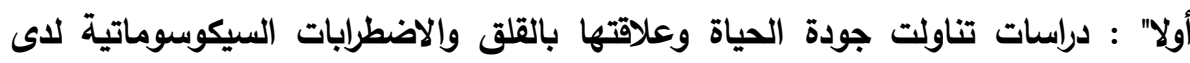
عينات مختلفة :

دراسة تايلور (Taylor, 1999) التي هدفت لدراسة العوامل المرتبطة بجودة الحياة

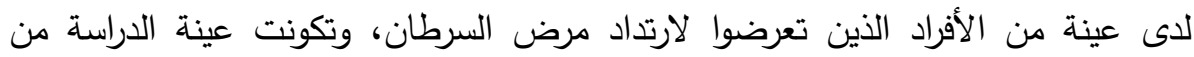

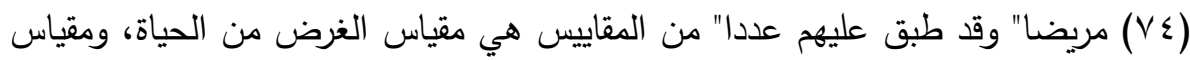

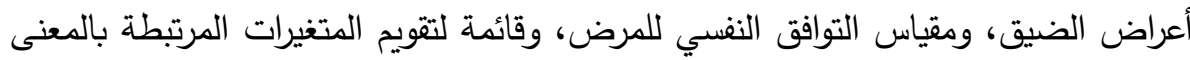
ومقياس الاعتماد الاجتماعي، وكثفت نتائج الدراسة عن ارتباط سالب بين معنى وجئ وهودة

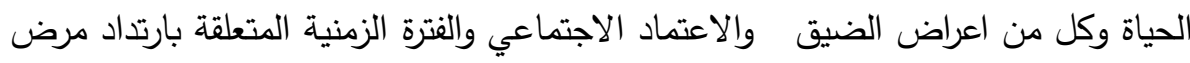

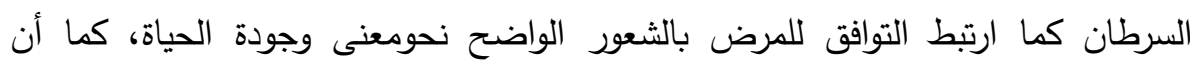
المبحوثين المتزوجين كان لديهم غرض ودافع للحياة بالمقارنة بالمبحوثين غير المتزوجين، وقد أكدت نتائج الدراسة أن معنى وجودة الحياة يتداخل مع الآثار الجسمية والنفسية

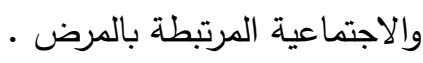

ودراسة مارجان ( Margan,R, 2003 ) التي هدفت إلى فحص جودة الحياة في

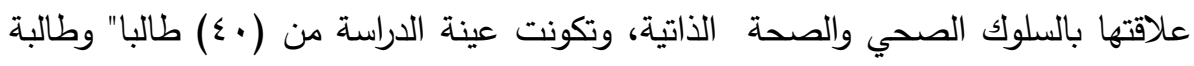
من طلاب الجامعة، واستخدم الباحث مقياس لقياس جودة الحياة ، وارسال عمليات

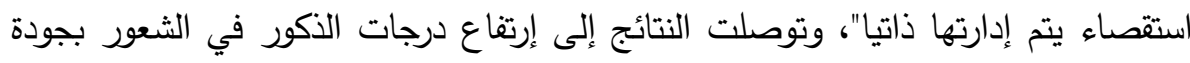

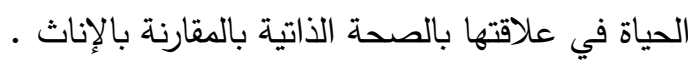


ودراسة كلاسن وآخرون ( Klassen et al., 2004 ) بعنوان "الصحة المرتبطة بجودة الحياة لاى الطلاب ذوي قصور الانتباه المصحوب بالنشاط الزائد" . وهدفت لتتيييم

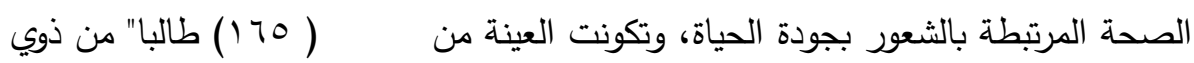

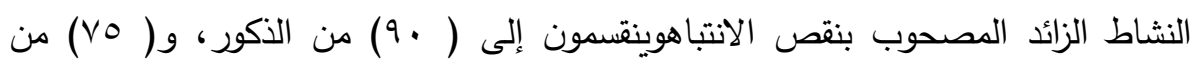

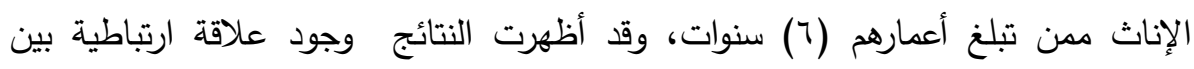
الاصابة بالنشاط الزائد وانخفاض الصحة النفسية للفرد وما يتضمنه ذلك من انخفاض

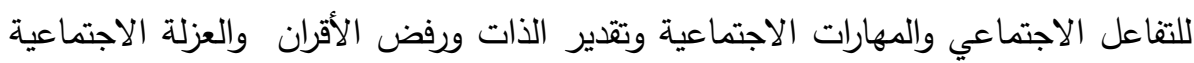
والسلوك الاندفاعي، مما يؤثر على الشعور بجودة الحياة لدى الطلاب ذوي النشاط الزائد

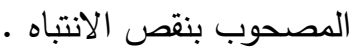
كذلك قام شادو(Chaudieu,2008 ) بدراسة هدفت للكثف عن العلاقة بين

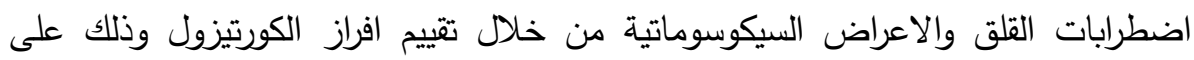

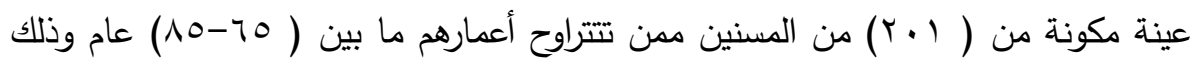

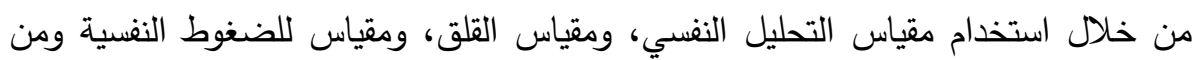
أهم نتائج الدراسة وجود زيادة افراز الكورتيزول في المواقف التي ترتبط باضطرابات القلق في ومني

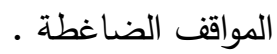
وكذلك دراسة ونجينج وأخرون ( Wenging,et al.,2004 ) بعنوان " الأعراض السيكوسوماتية وعلاقتها بأساليب المواجهة وتأثير ذلك على جودة الحياة لدى مرضى درانى

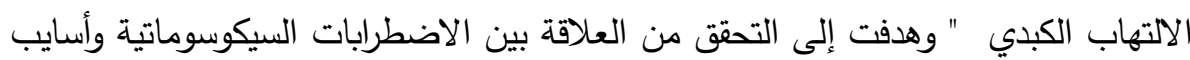

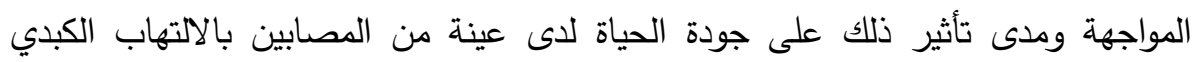
الوبائي "B" وتم استخدام مقياس الاضطرابات السيكوسوماتية، ومقياس أساليب المواجهة، وقد أظهرت النتائج وجود ارتباط موجب ودال بين الاضطرابات السيكوسوماتية وأسايب

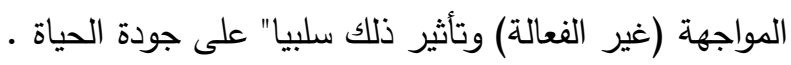

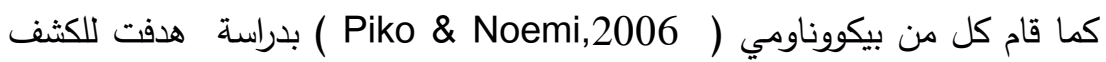

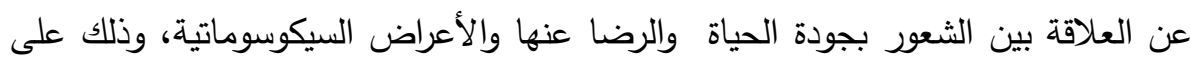

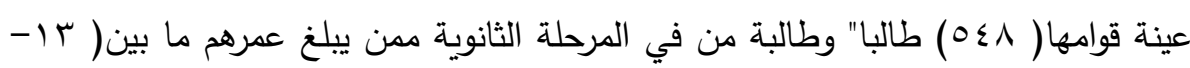

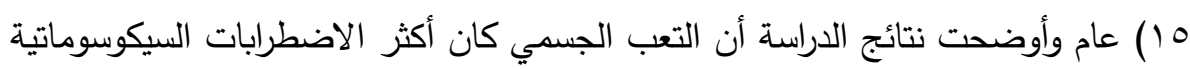

\section{هبلة الإرشاد النفسي، العدد 01، ع1 ، أبريل 19 r r}


شيوعا" بين الجنسين كالثكوى من الصداع المتكرر والام الظهر السفلية، وكذلك انخفاض

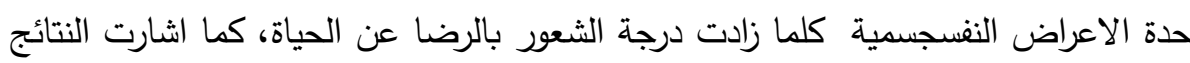

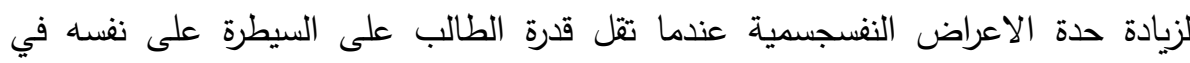

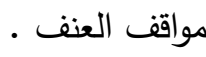

وهدفت دراسة زينب شقير ( • (ب+r) إلى التعرف على العلاقة الارتباطية بين جودة

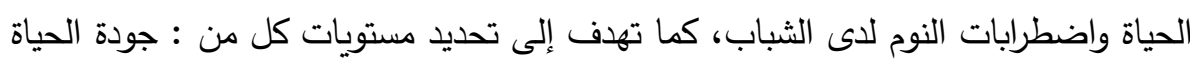

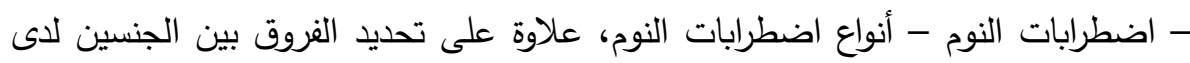

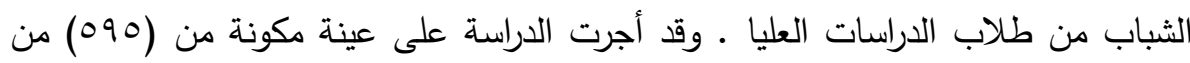

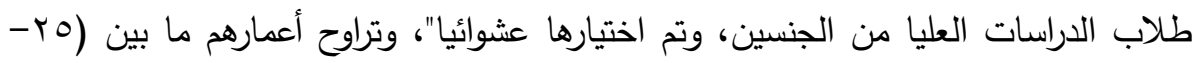

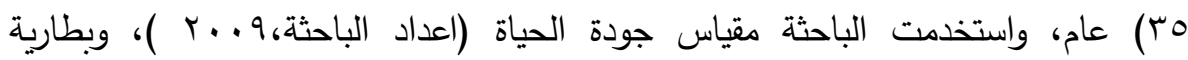

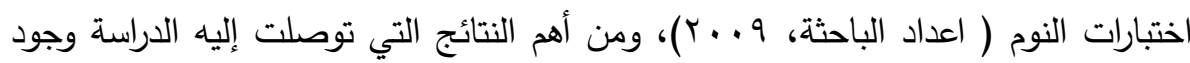

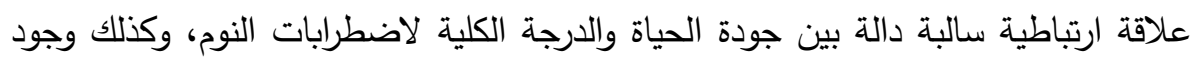
فروق في الشعور بجودة الحياة لصالح الذكور مقارنة بالإناث . ثانيا" : الدراسات التي تناولت جودة الحياة لاى طلاب الجامعة وعلاقتها بمتغيرات أخرى

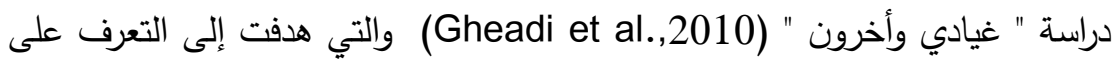

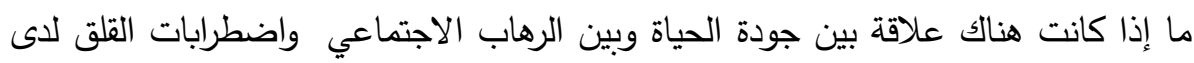

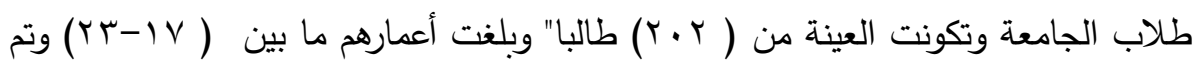

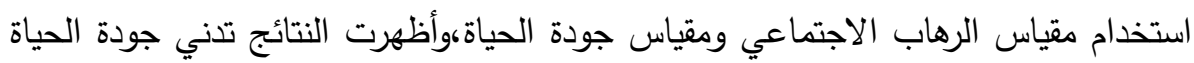

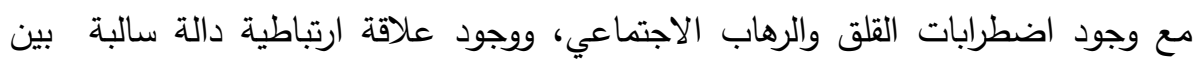

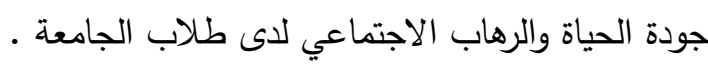

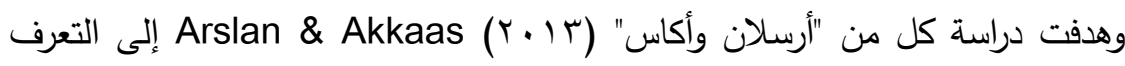

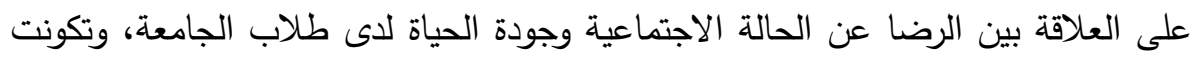

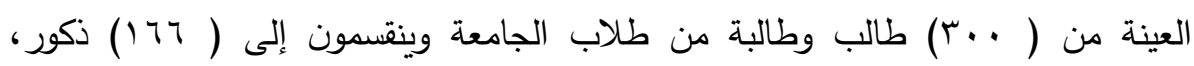

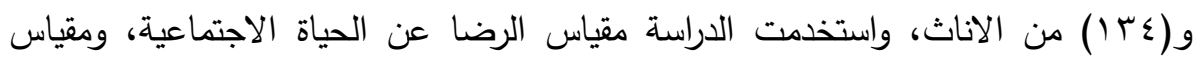

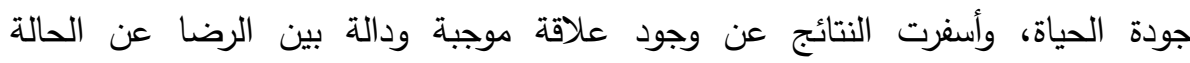


الاجتماعية وجودة الحياة لدى عينة الدراسة، كما أسفرت النتائج عن عدم وجود فروق دالة بين متوسطات درجات الطلاب في متغير جودة الحياة ترجع للفرقة الدراسية .

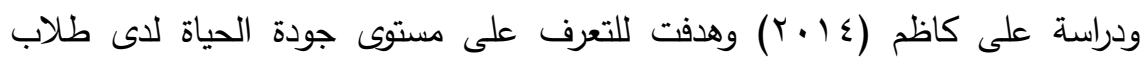

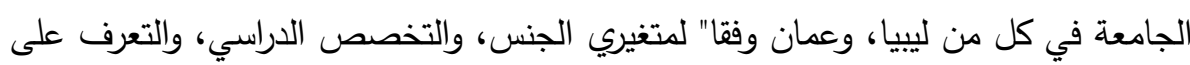

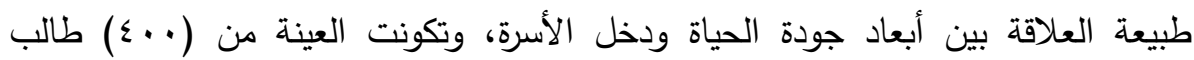

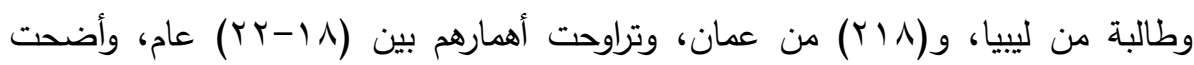

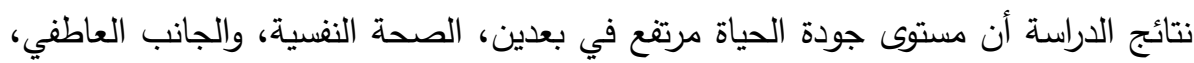

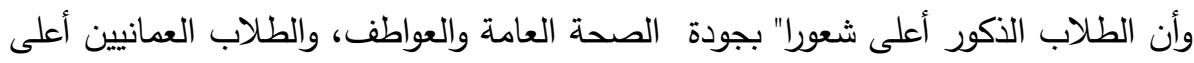
جودة في شغل وادارة الوقت بالمقارنة بالطلاب الليبيين •

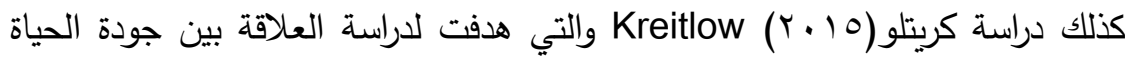
وكل من التدين والتمسك بالقيم الخلقية والحالة المعنوية لدى طلاب الجامعة وتكونت العينة

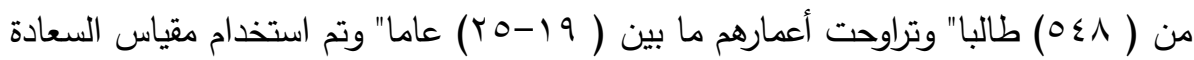

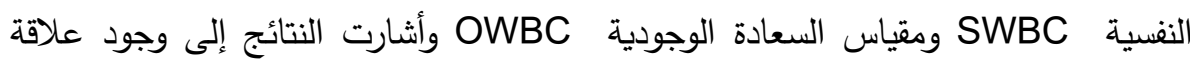
ارتباطية دالة وموجبة بين جودة الحياة والسعادة النفسية والوجودية .

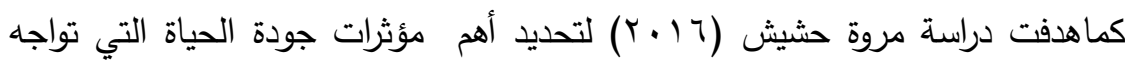

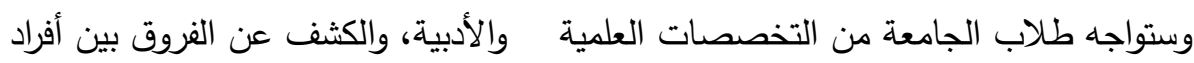
العينة في كل من جودة الحياة والتفكير الايجابي والسلبي وفقا" للمتغيرات الدراسية، وتكونت

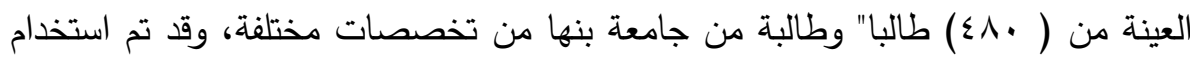
مقياس جودة الحياة ( Keyes,2002 ) تعديل الباحثة، ومقياس التفكير الايجابي والسلبي (

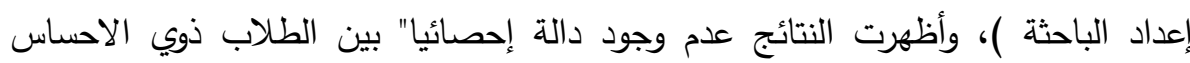

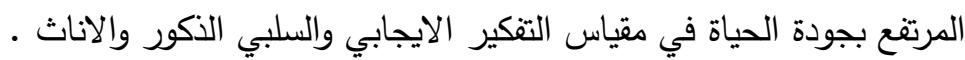

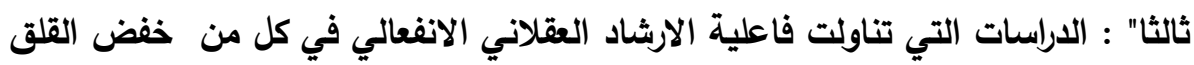
والاضطرابات السيكوسوماتية وتحسين جودة الحياة لاعى عينات مختلفة : وتتتاول هذه الفئة الدراسات التي إستهدفت دراسة فاعلية البرامج الارشادية المستخدمة في خفض القلق وتحسين جودة الحياة وذلك كما يلي:

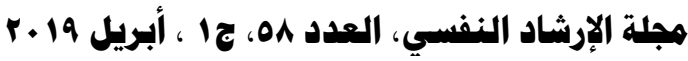


قام جين ( Gene, 1986$)$ بدراسة هدفت لفحص الأسلوب العقلاني للمواجهة كأسلوب

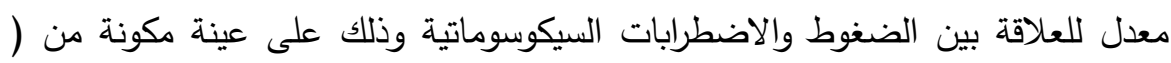


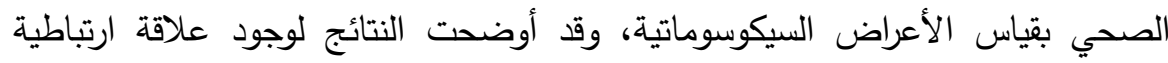

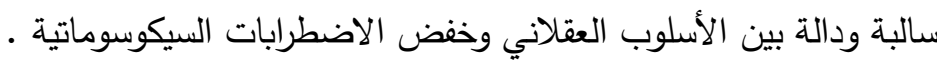

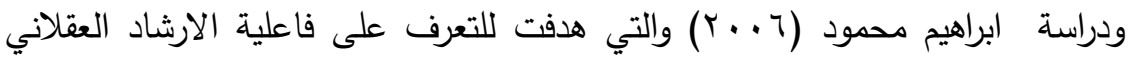

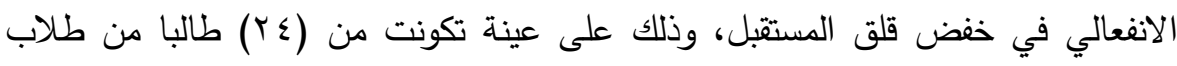
التعليم الثانوي التجاري وتم تطبيق مقياس قلق المستقبل، وبرنامج ارشادي عقلاني انفعالي

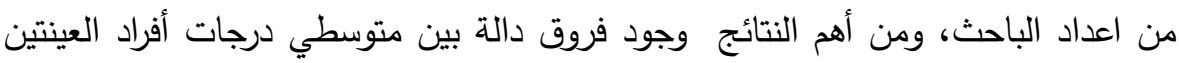

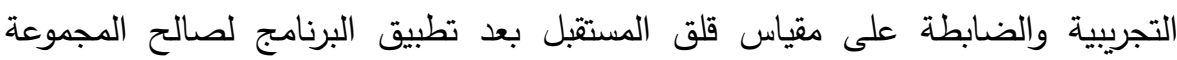
التجريبية، بينما لا توجد فروق دالة بين متوسطي درجات الفراد المجموعة التجريبية

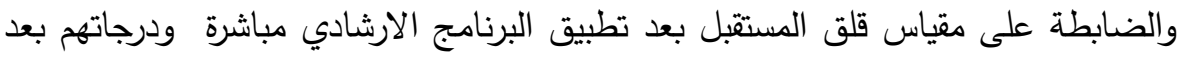

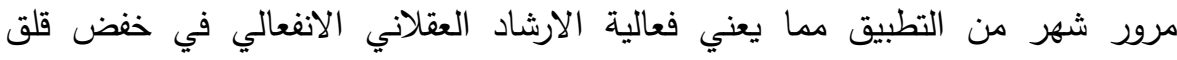

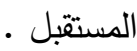

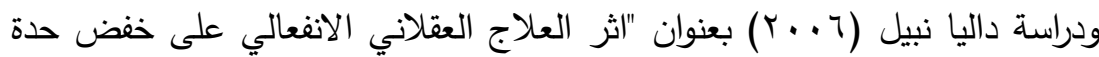

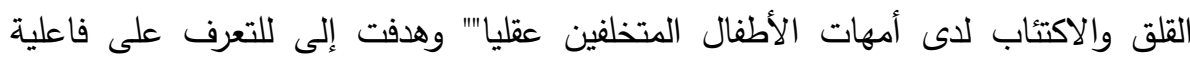

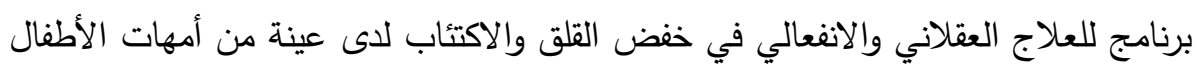

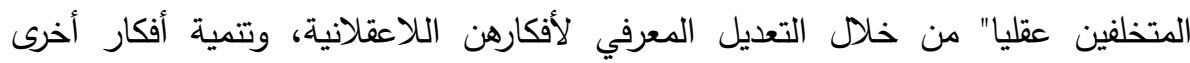

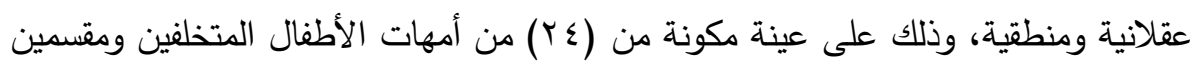

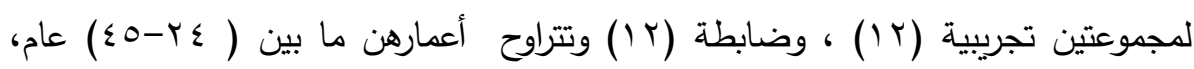

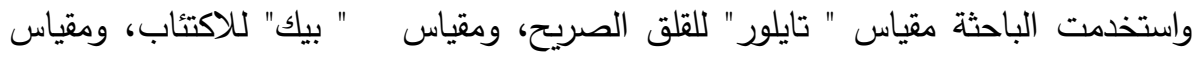

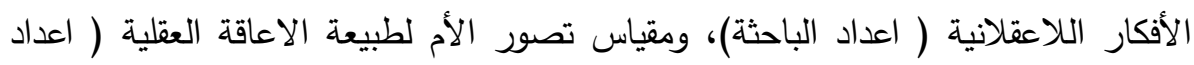

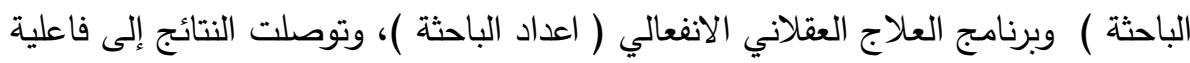

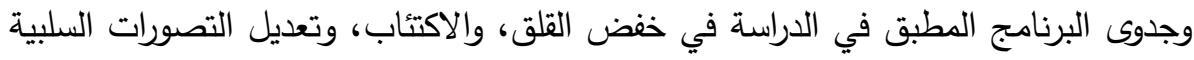

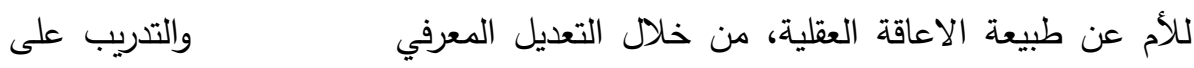

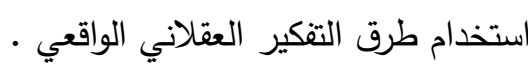

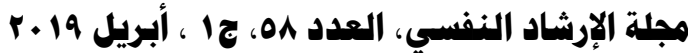




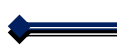

كما قام برنوفك وآخرين (Perinovic, et al.,2007 ) بدراسة لفحص العلاقة بين الاساليب المعرفية لمواجهة الاضطرابات السيكوسوماتية، والضغوط لدى المراهتين وقد تكونت عينة الدراسة من (101) من المراهقين وطبق عليهم مقياس الاساليب المعرفية للمواجهة، ومقياس الضغوط، ومقياس الاضطرابات السيكوسوماتية ومن أهم نتائج هذه

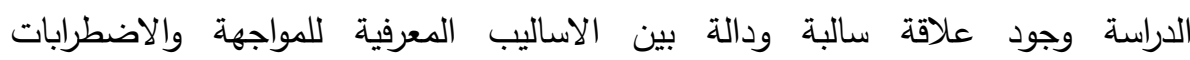
السيكوسوماتية اي ان استخدام اساليب المواجهة المعرفية اكثر فاعلية في تخفيف ودله الاضطرابات السيكوسوماتية.

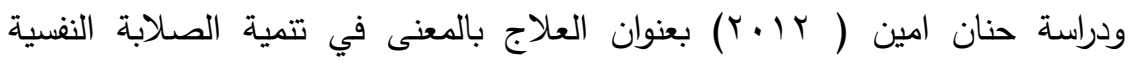

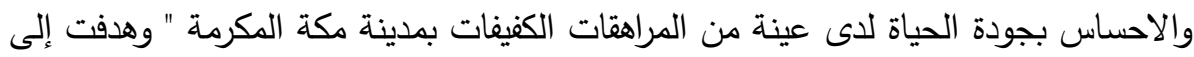

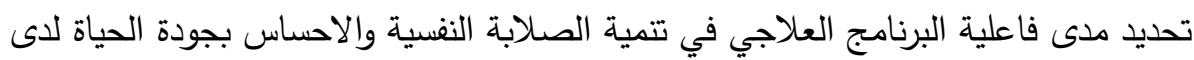
عينة من المراهقات الكفيفات، وتكونت عينة الدراسة من ( • ب) مراهقة كفيفة وتتقسم العينة

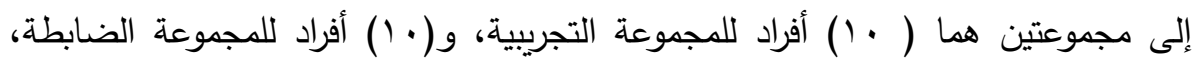
واستخدمت الباحثة مقياس الصلابة النفسية، ومقياس جودة الحياة، وخلصت النتائج إلى الى وجود فروق دالة إحصائيا" بين متوسطي درجات المجموعة التجريبية في التطبيق التبلي

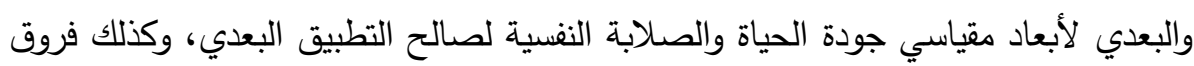

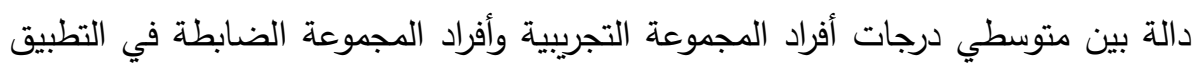
البعدي لأبعاد مقياسي الصلابة النفية وجودة الحياة لصالح المجموعة التجريبية مما يثبت درجيت

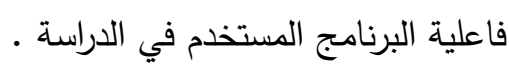

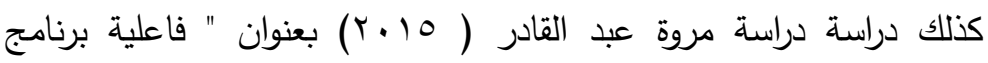
ارشادي عقلاني انفعالي سلوكي لتحسين جودة الحياة لاى طالبات دبلوم التوجيه والارشاد بجامعة الملك خالا " وهدفت إلى التحقق من فاعلية المستخدم في تحسين

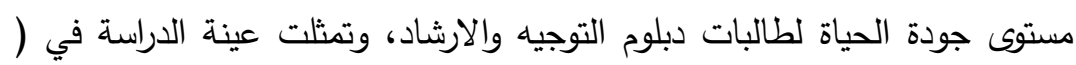

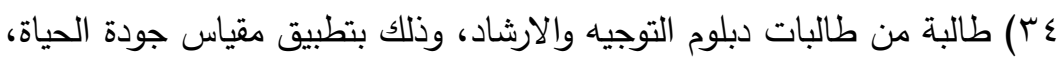

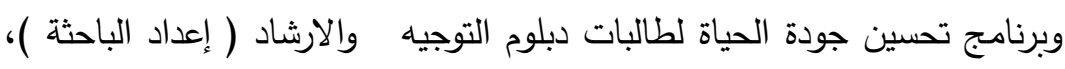
وتوصلت نتائج الدراسة لوجود فروق دالة إحصائيا" بين درجات التطبيق القبلي

\section{هجلة الإرشاد النفسي، العدد 01، ج1 ، أبريل 19 r r}




\section{د. داليا نبيل حافظ}

والبعدي لصالح التطبيق البعدي وفاعلية البرنامج المستخدم في تحسين جودة

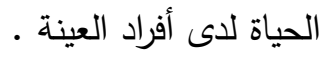

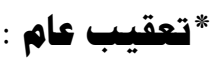

يتضح من خلال عرض الدراسات السابقة لنا ما يلي : ا-بعض الدراسات السابقة التي تتاولت جودة الحياة في علاقتها ببعض المتغيرات لم

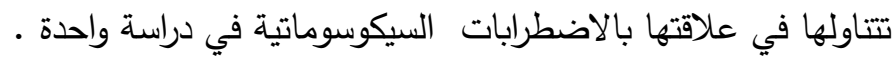
r - ظهور تعارض في نتائج بعض الدراسات السابقة فيما يتعلق بالفروق بين الذكور

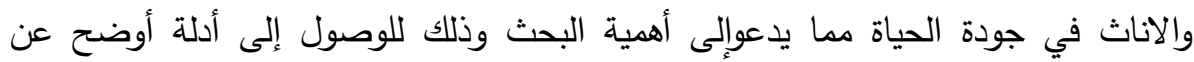

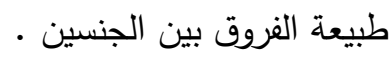
r- عدم تطرق الدراسات إلى الأعراض الجسمية والنفسية المترتبة على انخفاض مستوى لهـ جودة الحياة ، وكيفية الوصول إلى الطرق الوقائية والعلاجية السليمة . ع- اتفاق الدراسات على وجود علاقة دالة بين القلق وجودة الحياة وبين الاضطرابات

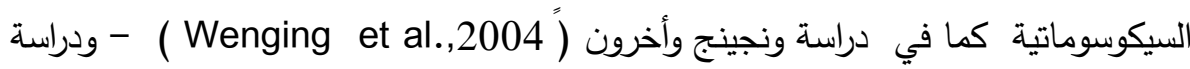
شادو (Chaudieu, 2008) ه-امتاز هذا البحث عن الدراسات السابقة بأنه لا توجد دراسة عربية حديثة تتاولت فاعلية برنامج لخفض القلق وتحسين جودة الحياة للى طلاب الجامعة ذوي الاضطرابات السيكوسوماتية من الجنسين على حد علم الباحثة .

\section{فروض الدراسة :}

ا-توجد فروق دالة إحصائيا" بين متوسطات رتب درجات طلاب وطالبات الجامعة ذوي الاضطرابات السيكوسوماتي أفراد المجموعة التجريبية (الذين تلقوا البرنامج الارشادي) ومتوسطات رتب درجات طلاب وطالبات الجامعة ذوي الاضطرابات السيكوسوماتية أفراد المجوعة الضابطة (الذين لم يتلقوا البرنامج الارشادي) في القياس البعدي للبرنامج في كل

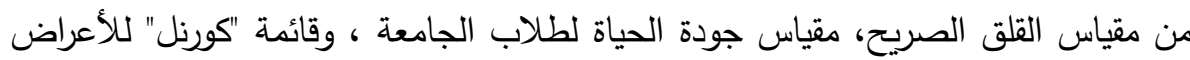

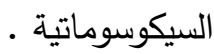

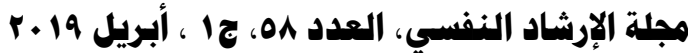

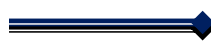

$(101)$ 
r- توجد فروق دالة إحصائيا" بين متوسطات رتب درجات طلاب وطالبات الجامعة ذوي

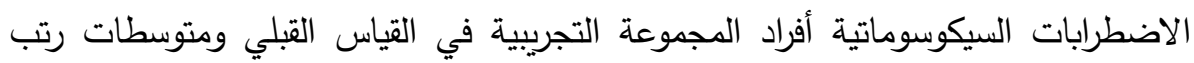
درجاتهم في القياس البعدي للبرنامج في كل من مقياس القلق الصريح ، ومقياس جودة الحياة

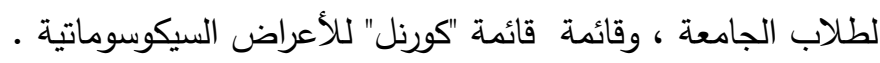

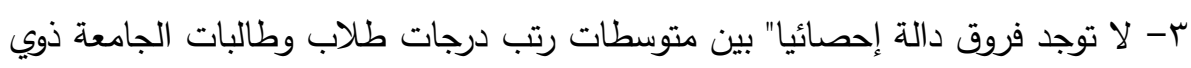
الاضطرابات السيكوسوماتية أفراد المجموعة التجريبية في القياسين البعدي والتتبعي لتطبيق البرنامج في كل من مقياس القلق الصريح، ومقياس جودة الحياة لطلاب الجامعة، وقائمة

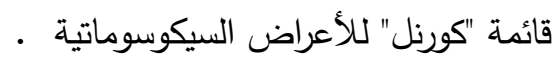

\section{المنهج والاجراءات :}

أولا" : المنهج

تتبع الدراسة الحالية المنهج شبه التجريبي نظرا لطبيعة الدراسة ومشكلتها والتي تتعلق بالوقوف على أثر برنامج ارشادي مقترح في الدراسة في خفض حدة القلق وتحسين جودة

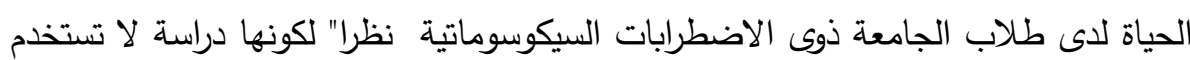
الاختيار العشوائي لأفراد العينة أوالتتويع العشوائي للظروف التجريبية لإئية ـ وبالتالى فالدراسة تتبع المنهج شبه التجريبي الذى ينطوى على معالجة تجريبية تطبق على عينة تم اختيارها

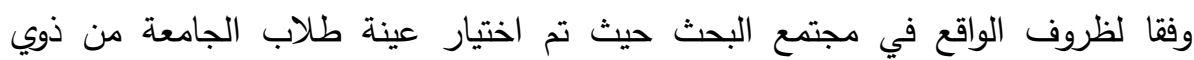
الاضطرابات السيكوسوماتية على ما هي عليه في واقع الأمر • حيث يتم التحقق من فاعلية

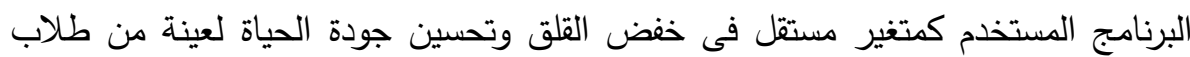

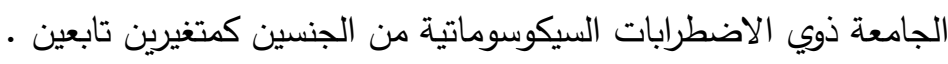
ثانيا" : عينة الدراسة الكلية تكونت العينة الكلية للبحث من ( 9 9) من المرضى المترددين على العيادات والمراكز

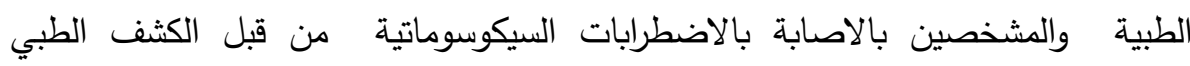
بالاضطرابات السيكوسوماتية، وكذلك من خلال التأكد من وجود سبب سيكولوجي لاى أفراد تلك المجموعة من خلال تطبيق قائمة " كورنل" للأعراض السيكوسوماتية وقد اختير أفراد تلك العينة ممن حصلوا على أعلى الدرجات على هذه القائمة على المقاييس الفرعية التي

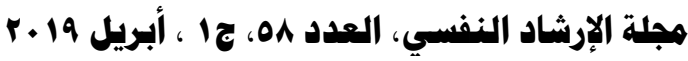




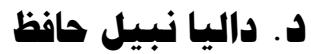

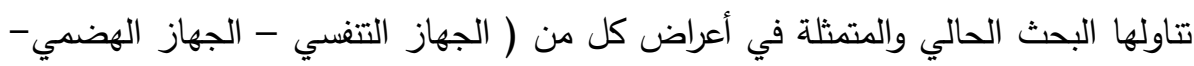

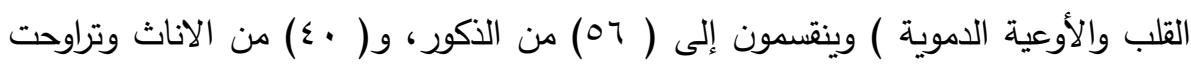

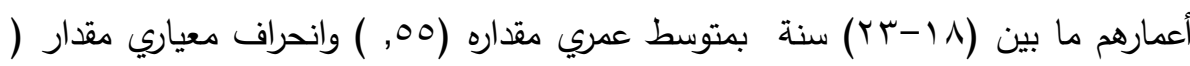

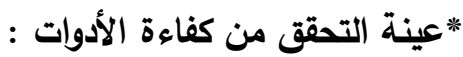

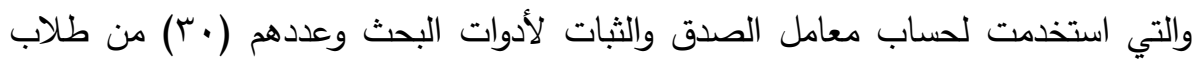
الجامعة ذوي الاضطرابات السيكوسوماتية من الجنسين المترددين على العيادات والمراكز

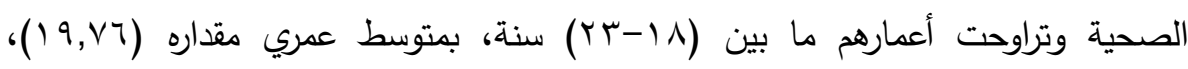

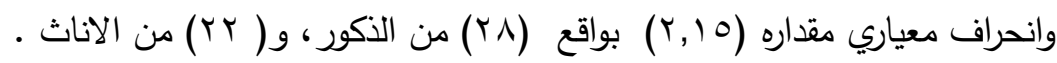

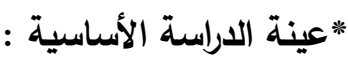

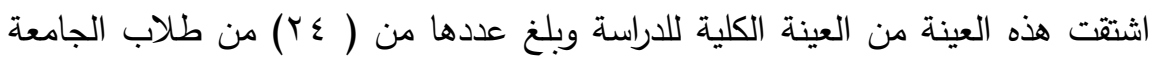

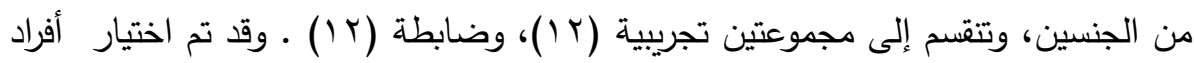

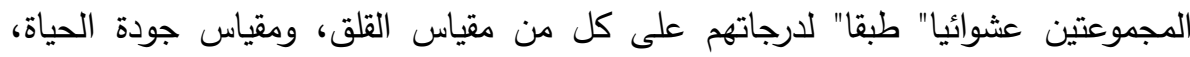

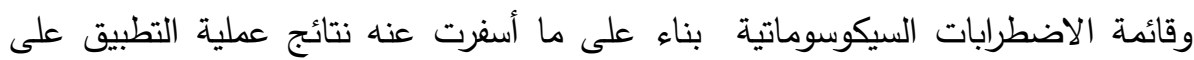
المقاييس السابقة وهم الأعلى درجات في كل من قائمة الاضطرابات السيكوسوماتية،

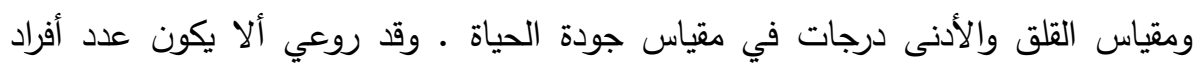

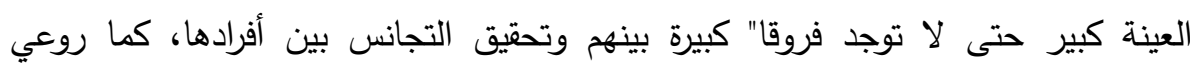

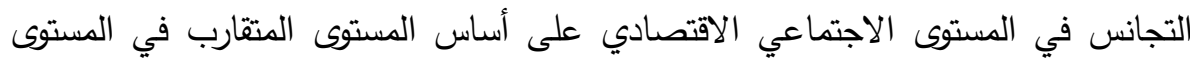

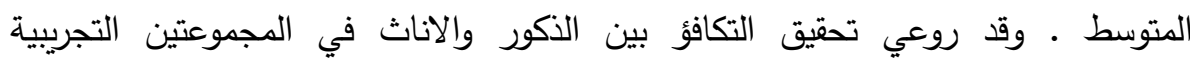
والضابطة في العمر، وقد تم توزيع العينة كما هوموضح في الجدول التالي لئي

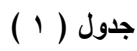

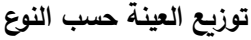

\begin{tabular}{|c|c|c|c|}
\hline المجموع & المجموعة التجريبية & المجموعة الضابطة & النوع ال الن \\
\hline ir & 4 & 4 & ذكور \\
\hline ir & 4 & 7 & اناث \\
\hline$r \varepsilon$ & ir & ir & ميج (مج \\
\hline
\end{tabular}

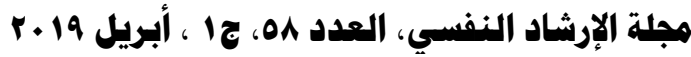


وقد روعي ضرورة تجانس أفراد المجموعتين ( التجريبية - الضابطة) في بعض المتغيرات

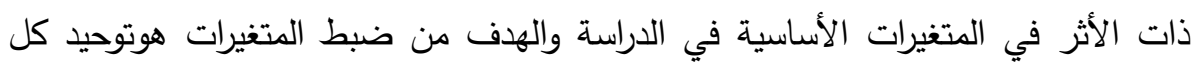
أفراد العينة العلاجية لتحقيق التكافؤ بين المجموعة التجريبية والمجموعة الضابطة وذلك فئك حتى لا يسبب أي متغير خارجي تأثيرا خلاف تأثير البرنامج العلاجي مما يستديه لئهي

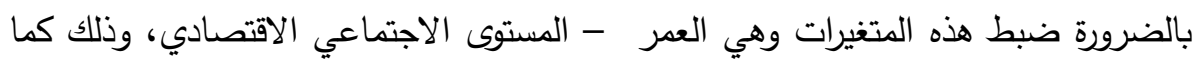

$$
\text { يلي : }
$$

فقد تراوحت أعمار أفراد المجموعة التجربية (ن= Y I ) والمجموعة الضابطة

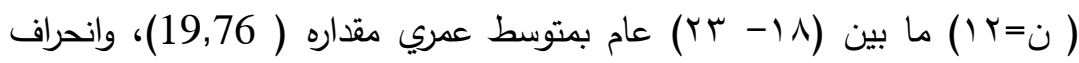
معياري مقداره ( 2,15)، وللتحقق من تجانس عينة البحث (التجريبية- الضابطة) في متغير

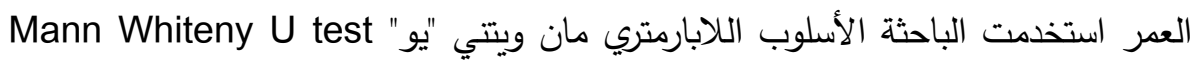
وذلك لصغر حجم العينة العلاجية - وفيما يلي جدول يوضح دلالة الفروق في المتوسطات في متغير العر بين المجموعتين التجريبية والضابطة .

\begin{tabular}{|c|c|c|c|c|c|c|}
\hline الدلالة & قيمة U & $\begin{array}{l}r \\
u\end{array}$ & $\begin{array}{l}1 \\
u\end{array}$ & 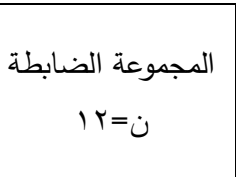 & المجموعة التجريبية & 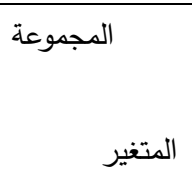 \\
\hline \multirow{2}{*}{ غير دال } & \multirow{2}{*}{ 1.VA- } & \multirow{2}{*}{$r 9.0$} & \multirow{2}{*}{110} & مجموع الرتب & مجموع الرتب & \multirow{2}{*}{ العمر } \\
\hline & & & & INT.O & $1 \cdot v$ & \\
\hline & 0 & 0 & & $1.97=z$ & قيمة"U" الجن & \\
\hline & ي ו •.. & عند مص & & ولية=1. ب. & قيمة"U " الجا & \\
\hline
\end{tabular}

جدول (r) (r)

يتضح من جدول (Y) أنه لا توجد فروق دالة إحصائيا بين المتوسطات في متغير العمر بين المجموعة التجريبية, والمجموعة الضابطة . ثالثا" : أدوات البحث : استخدمت الباحثة الأدوات التالية :

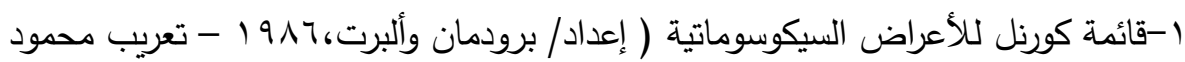

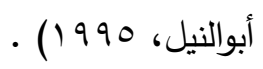

\section{هجلة الإرشاد النفسي، العدد 01، ج1 ، أبريل 19 r r}




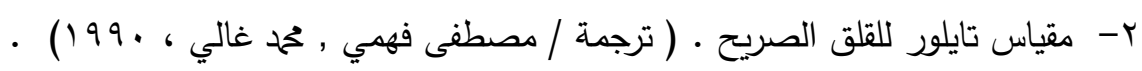

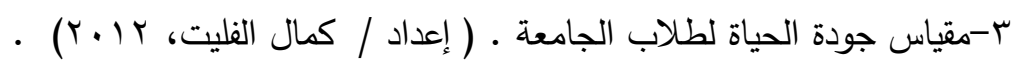

ع-برنامج ارشادي عقلاني انفعالي لخفض القلق وتحسين جودة الحياة . ( اعداد الباحثة ) )

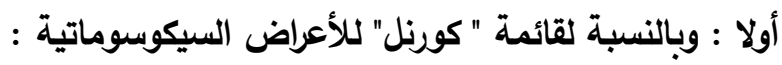

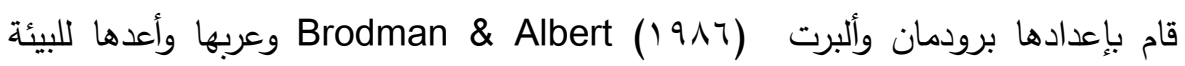

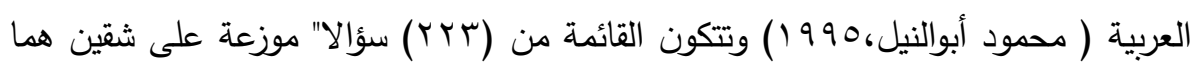

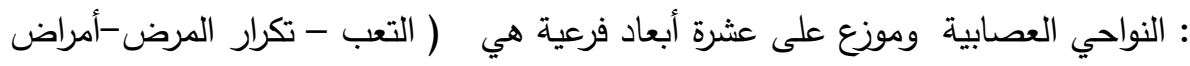

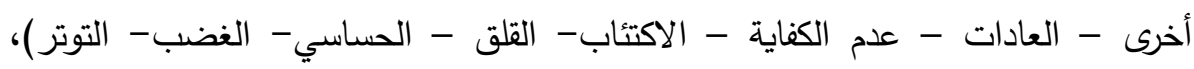

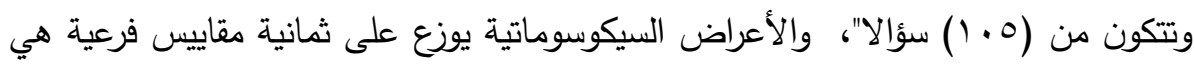

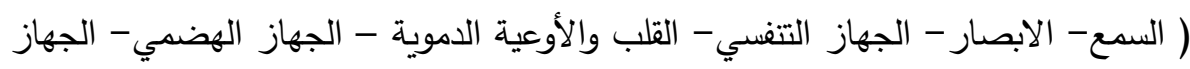

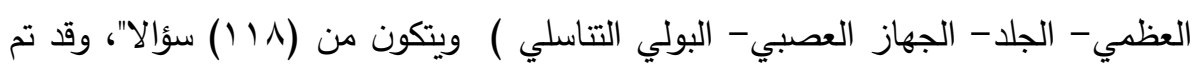

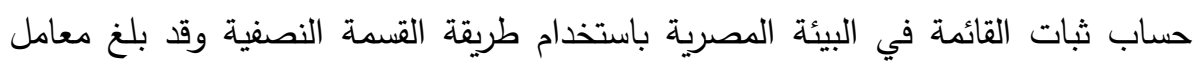

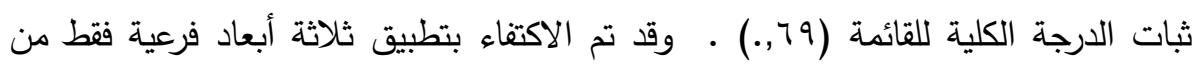

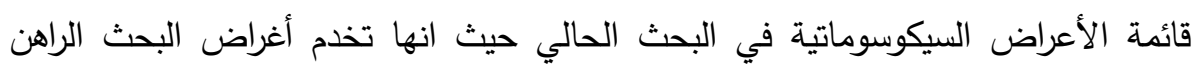

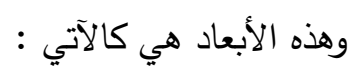
ا-الجهاز التتفسي ويشير هذا البعد : إلى الأعراض البدنية المصاحبة للإضطراب الانفعالي

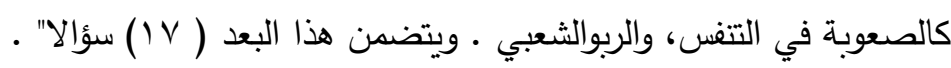

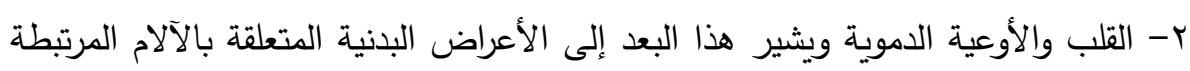

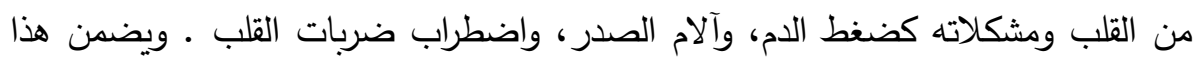

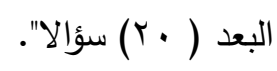
ب-الجهاز الهضمي ويشير هذا البعد إلى الأعراض البدنية المتعلقة بآلام الجهاز الهضمي

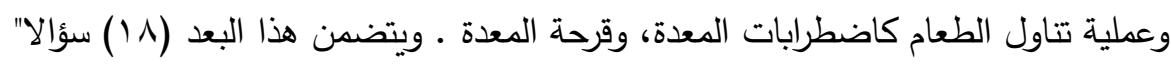

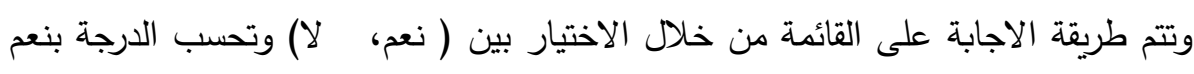

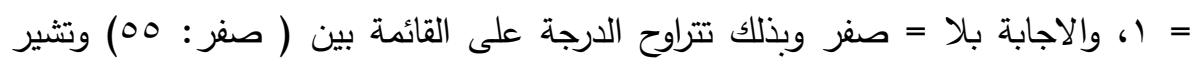

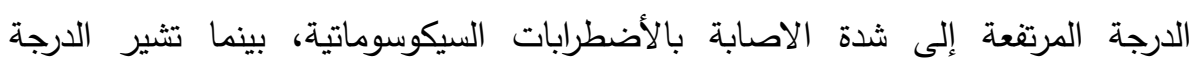

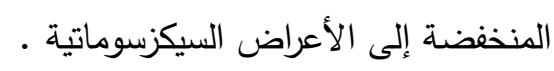

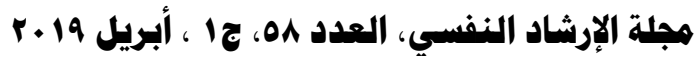


وقد قامت الباحثة بحساب الصدق والثبات للمقاييس الثلاثة من القائمة المستخدمة في

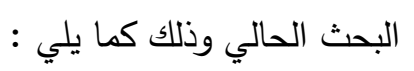
أولا" : الصدق : تم التحقق من صدق الأداه باستخدام الصدق التلازمي من خلال حساب

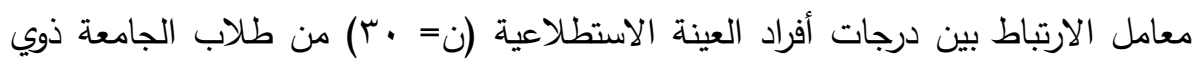

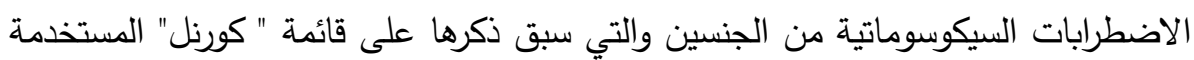

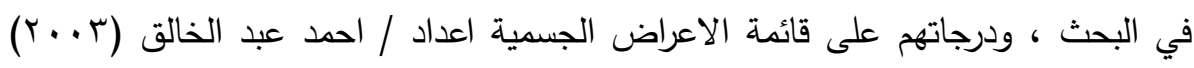
Somatic Symptoms inventory عند مستوى l ب. (,.,

كما تم حساب صدق المقاييس فقد تم استخدام الصدق التمييزي على العينة المستخدمة في ماتي التحقق من الصدق والثبات والتي سبق ذكرها من خلال المقارنة بين مجموعتين متضادتين

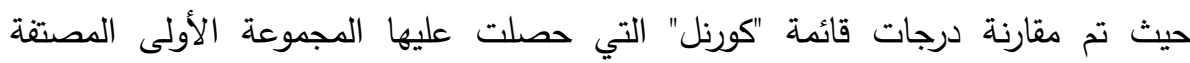

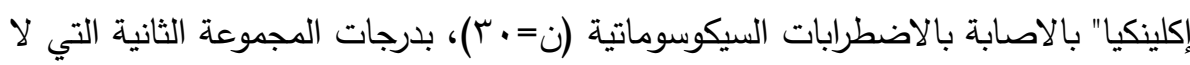

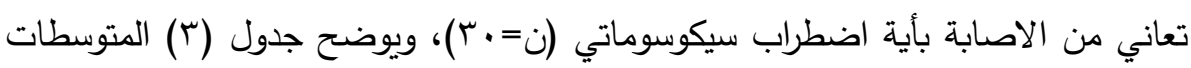

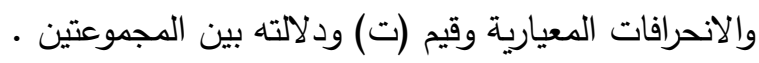
جدول (r) المتوسطات والانحرافات المعيارية وقيم (ت) ودلالنها

\begin{tabular}{|c|c|c|c|c|c|}
\hline \multirow[t]{2}{*}{ قيمة (ت) } & \multicolumn{2}{|c|}{ 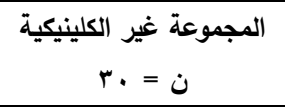 } & \multicolumn{2}{|c|}{ 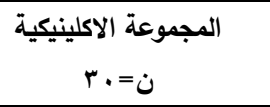 } & \multirow[t]{2}{*}{$\begin{array}{l}\text { المقاييس الفرعية المجموعة } \\
\text { المقية }\end{array}$} \\
\hline & $\varepsilon$ & م & $\varepsilon$ & م & \\
\hline$* * 4, r r$ & $r, r r$ & $9,7 V$ & $r, r \wedge$ & 10,17 & الجهاز التنفسي \\
\hline$* * V, r V$ & $\{, \varepsilon Y$ & $1 \varepsilon, 1 Y$ & r,rr & $17,1 r$ & الجهاز الهضمي \\
\hline *** & r,Ir & $11, r_{0}$ & $r, \& \wedge$ & IV,ro & القلب والأوعية \\
\hline **\% & $\checkmark, \vee \wedge$ & ro,. $\varepsilon$ & V,or & $\varepsilon \Lambda, O r$ & المجموع \\
\hline
\end{tabular}

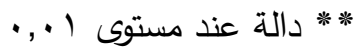
*دالة عند مستوى 0 •,.

ويوضح الجدول السابق (r) وجود فروق دالة احصائيا بين المجموعتين الاكلينكية وغير

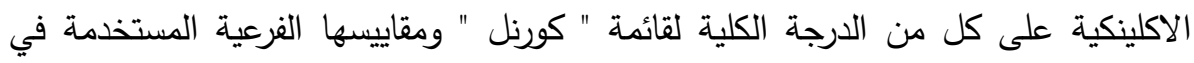




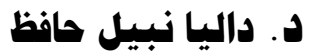

الدراسة الحالية ( الجهاز التنفي- القلب والأوعية الدموية - الجهاز الهضمي ) مما يشير الإئ

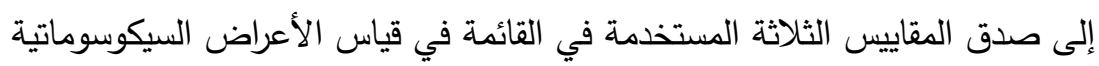

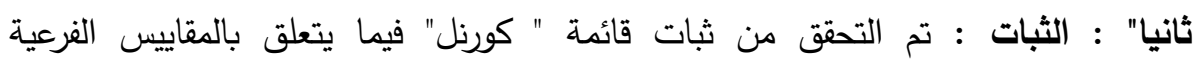

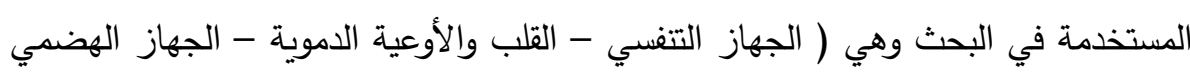

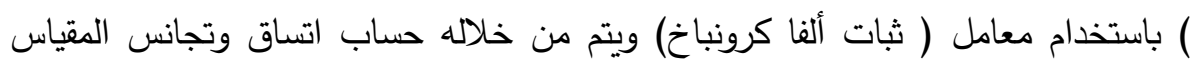

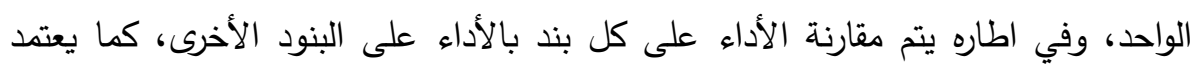

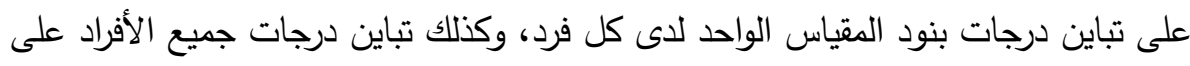

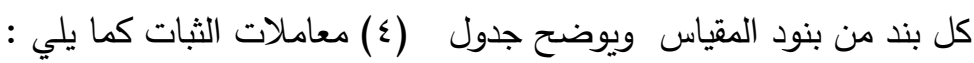

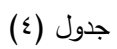

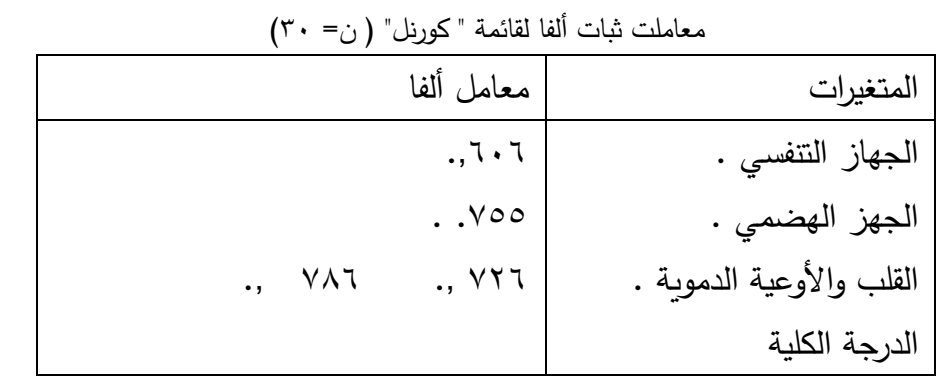

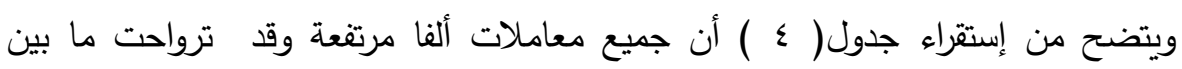

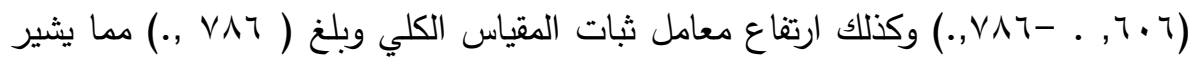

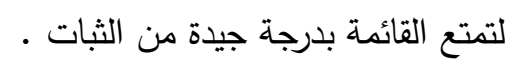

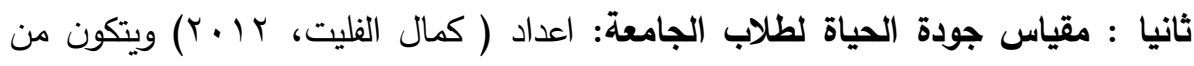

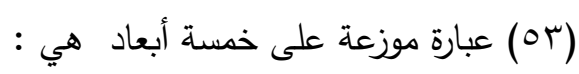
1- جودة الحياة الاجتماعية: ويشير إلى شعور الفرد بالسعادة التعادة في علاقاته الايجابية

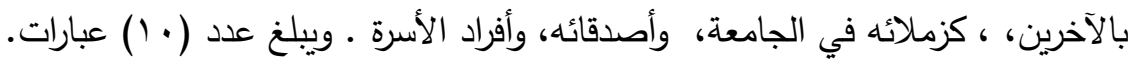

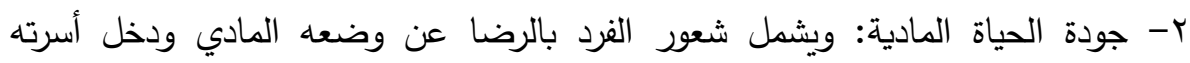

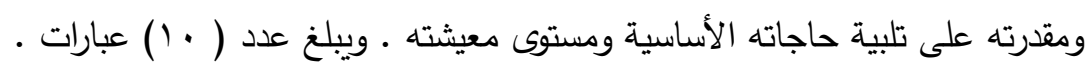

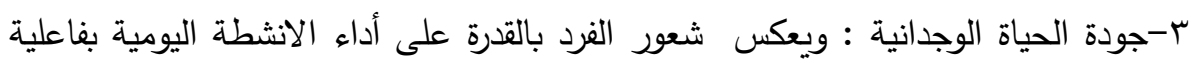

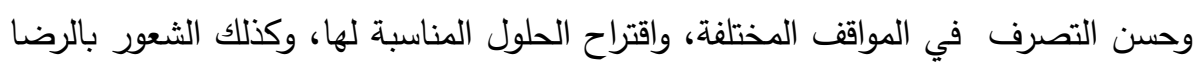

\section{مجلة الإرشاد النفسي، العدد OA، 1 ، أبريل 19 +r}


عن الذات والسعادة في إدارة الحياة والثقة بالنفس عند التعامل مع الآخرين • ويبلغ ( r ا) عبارة . ع-جودة الحياة الأكاديمية : ويشير إلى شعور الفرد بالسعادة والرضا في علاقاته بأساتذته،

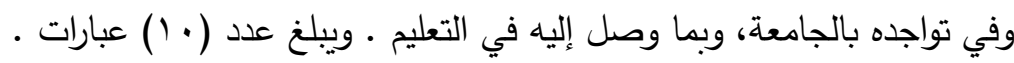

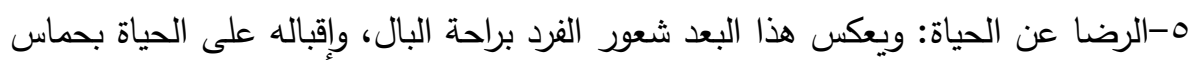

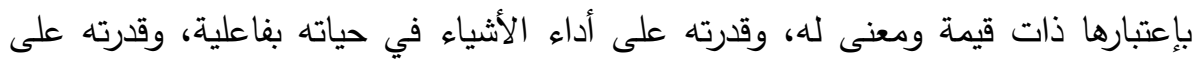

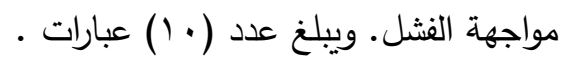
وتتم الاجابة على المقياس وفقا" لتدرج ثلاثي على النحو التالي: ( كبيرة = ب، متوسطة

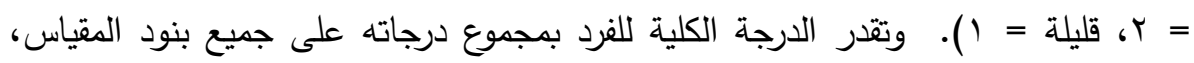
وتشير الدرجة المرتفعة على المقياس إلى إدراك الفرد لجودة الحياة، واحساسه بالسعادة

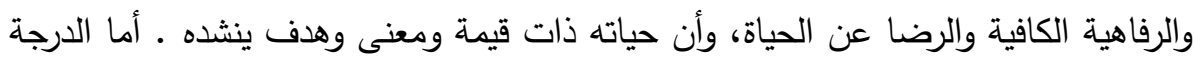

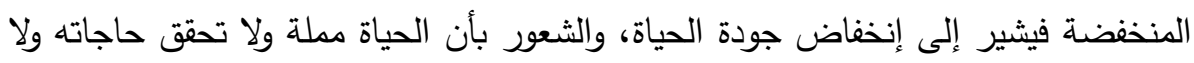
يثعر بالسعادة والرفاهية الكافية ـ وقد قام معد المقياس بحساب صدق المقياس من خلال طريقتين هما : ا-صدق المحكمين حيث تم عرض المقياس في صورته النهائية على مجموعة من أساتذة

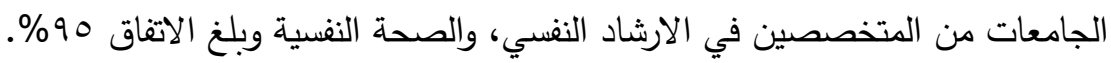

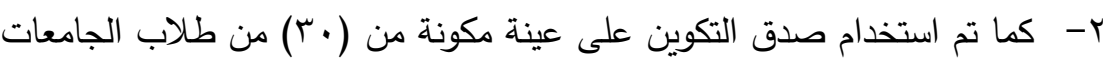
من الجنسين من خلال حساب معامل الارتباط بين درجة كل بعد من أبعاده

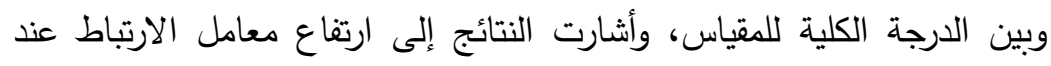

$$
\text { مستوى ( ( ., •) مما يدل على صدق المقياس. }
$$

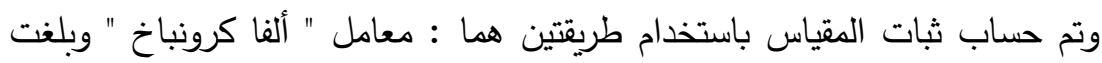
قيمته ( (1, •)، وكذلك تم استخدام طريقة التجزئة النصفية وبلغت قيمة معامل الارتباط

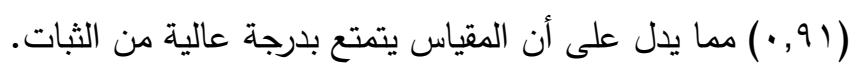

وقد تم حساب صدق مقياس الاضطرابات السيكوسوماتية على عينة الدراسة الحالية من خلال استخدام طريقة التجانس الاخلي كالتالي: معيات الاصطرات 
تم حساب معامل الارتباط بين كل عبارة وبين الدرجة الكلية لكل مقياس فرعي، وحساب

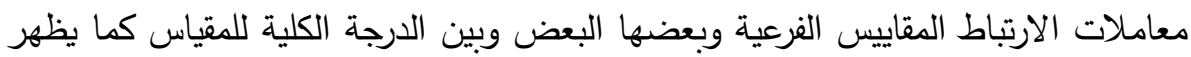
في كل من جدولي (0)، (†) كالتالي :

جدول (0)

يبين معاملات الارتباط بين المفردات والمقاييس الفرعية التي تتتمي إليها

\begin{tabular}{|c|c|c|c|c|c|c|c|c|c|}
\hline الارتباط & ( الرضا عن & الإرتباط معامل & ( الاكاديمية) & الإرتباط معامل & (جودة الحياة & الإرتباط معامل & (جودة الحياة & معامل & (اجودة الحياة \\
\hline$* * 07 \pi$ & $\varepsilon \varepsilon$ & $* *, V V r$ & $r \varepsilon$ & $* * *, 77 \varepsilon$ & r) & $* *, \vee, \vee \curlyvee 9$ & 11 & $*$, roq & 1 \\
\hline$* *, 00 \mathrm{r}$ & $\leq 0$ & $* * \cdot, \vee \vee \leqslant \varepsilon$ & ro & $* *,, \vee 00$ & rt & $* * *, \wedge \leqslant \uparrow$ & ir & $* * *, \leq T V$ & r \\
\hline ***,orr & $\leq 7$ & $* * \cdot, \wedge \leq r$ & r & $* *, 0 \leq 9$ & r & $* *$, orq & ir & $* * *, 0 Y \wedge$ & $r$ \\
\hline$* *$,ror & $\varepsilon v$ & $* *, r \wedge r$ & rv & $* *,, 7 \leq 9$ & $r \varepsilon$ & $* * ., 01 Y$ & $1 \varepsilon$ & $*, r, \wedge$ & $\varepsilon$ \\
\hline **,orr & $\varepsilon \wedge$ & $* * *, 7.0$ & ra & $* *, 00 \mathrm{~V}$ & ro & **, OYT & 10 & $* *,+, 1$. & 0 \\
\hline$* *, r \vee ч$ & $\leqslant 9$ & $* * \cdot, V \backslash V$ & rq & $* *, 0 \leq \leqslant$ & ry & $* *, 770$ & 17 & $* *$, *, Or & 1 \\
\hline$* *$, , TYo & o. & $* *, \wedge 0 \leqslant$ & $\varepsilon$. & $* *, 0 \leq 9$ & rV & $* *, \pi, T \leq$ & iv & $* *, 01 \leqslant$ & $v$ \\
\hline$* *,\{$ or & 01 & $* *, T \leq r$ & $\varepsilon 1$ & $* *, V / 4$ & rA & $* *, 010$ & 11 & $* *, 717$ & $\wedge$ \\
\hline$* * .0 r r$ & or & $* *, \vee \vee 9 r$ & $\varepsilon r$ & $* *, 7 / 0$ & rq & $* *, 770$ & 19 & דוז, • & 9 \\
\hline$* *, 07 \leqslant$ & or & $* *, \quad, 1 \leq 0$ & $\varepsilon r$ & $\begin{array}{l}* *, 0 \leq r \\
* *,, 717 \\
* *, \vee \vee>0 \\
* *,, \leq 00\end{array}$ & $\begin{array}{l}r . \\
r \\
r \\
r\end{array}$ & $* * \cdot, 0 \wedge \varepsilon$ & $r$. & $* *$, , Yoo & 1. \\
\hline
\end{tabular}

جدول (T)

يبين معاملات الارتباط بين المقاييس الفرعية وبعضها البعض وبين الدرجة الكلية للمقياس

\begin{tabular}{|c|c|c|c|c|c|c|}
\hline المقياس & $\begin{array}{c}\text { الرضا عن الحياة } \\
\text { (0) }\end{array}$ & $\begin{array}{c}\text { جودة الحياة } \\
\text { الاجتماعية }\end{array}$ & $\begin{array}{c}\text { جودة الحياة } \\
\text { الوجدانية }\end{array}$ & $\begin{array}{c}\text { جودة الحياة } \\
\text { المادية }\end{array}$ & $\begin{array}{c}\text { جودة الحياة (1) } \\
\text { الاجتماعية }\end{array}$ & معاملات الارتباط \\
\hline$* \%, O Y V$ & $*, r \leq 0$ & $\cdot, \cdot 10$ & $*, \Gamma \mid \leq$ & $\cdot, 110$ & - & (1)جودة الحياة الاجتماعية \\
\hline$* *, 701$ & $*, r \leqslant r$ & $* *, r V V$ & $* * 0,0 \leqslant r$ & - & & (ץ) جودة الحياة المادية . \\
\hline 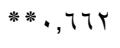 & *** & $* *, 191$ & - & & & (r) جودة الحياة الوجدانية . \\
\hline$* *, 0 \cdot V$ & $* * .07 \mathrm{~V}$ & - & & & & (ع) جودة الحياة الأكاديمية. \\
\hline$* *, 707$ & $* *, O \wedge r$ & & & & & (0) الرضا عن الحياة . \\
\hline- & - & - & - & - & - & المقياس الكلي \\
\hline
\end{tabular}

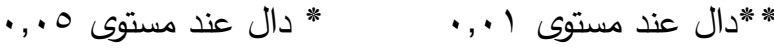

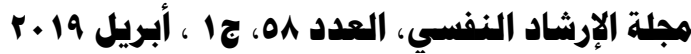


ويتضح من خلال الجدولين السابقين أن جميع معاملات الارتباط المتبادلة بين المفردات

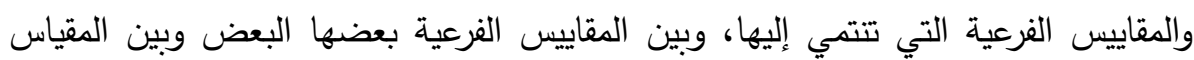

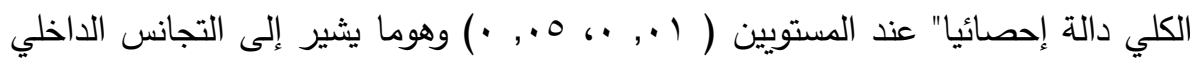
• للمقياس ثالثا : مقياس (تايلور) للقلق الصريح:

Taylor Manifest Anxiety Scale. (T.M.A.S) قام بإعداد هذا المقياس "جانيت تايلور". وقام بترجمته ونقله إلى اللغة العربية كل من (مصطفى فهمي,محم غالي -9190) ) وقد تم استخدام هذا المقياس في كثير من الدراسات والبحوث العربية والمصرية في مجال المراهقين والراشدين والكبار الأسوياء وغير الأسوياء.

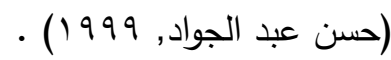
ويكثف هذا المقياس عن مستوى القلق لدى المفحوصين من خلاد خمس درجات تتراوح

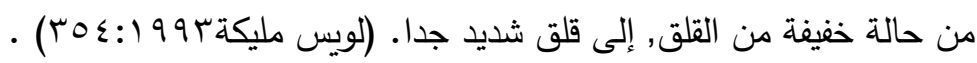
ويتكون هذا المقياس من خمسين (•0) بندا تتاسب المفحوصين الراشدين ويوجد للمقياس

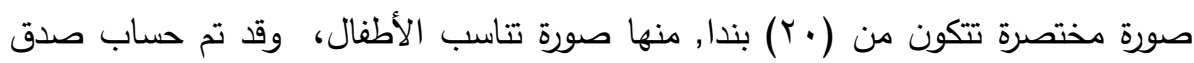

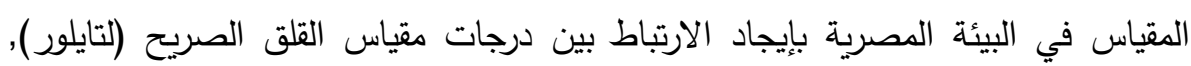

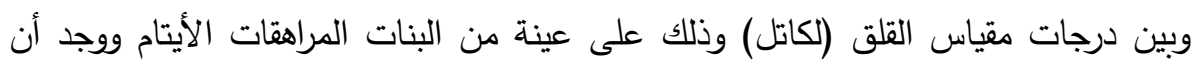
معامل الارتباط (T^^. ·) كما تم حساب صدق المقياس بإيجاد الارتباط بين الدرجات عليه وبين درجات مقياس (كاتل) على عينة أخرى من الأولاد والبنات المراهقين نزلاء الملاجئ ووجد أن معامل الارتباط(بی.. ). وبذلك يتضح أن مقياس القلق الصريح (لتايلور) يتميز التيل بدرجة صدق عالية (حسن عبد الجواد , 999 ()) . أما بالنسبة لثبات المقياس فقد اتضح أن الاتساق الداخلي للاختبار مرتفع نسبيا, فقد

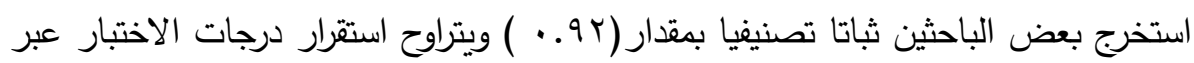

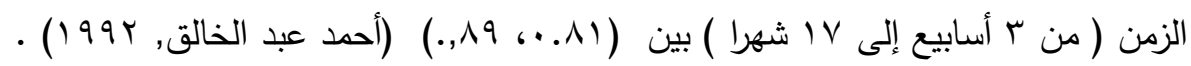
وقد تم اختيار هذا المقياس لتطبيقه على أفراد عينة الدراسة الحالية نظرا لسهولة فهم عباراته بالإضافة إلى أنه يتتاسب مع هدف البحث الحالي من حيث قياس درجة القلق الصريح 


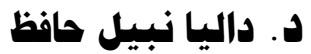

والظاهر لاى طلاب الجامعة ذوي الاضطرابات السيكوسوماتية هذا إلى جانب أنه قد تم

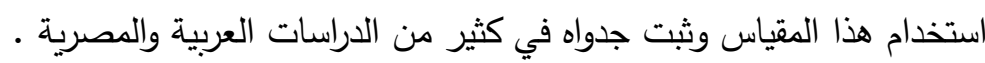
خامسا : برنامج الارشاد العقلاني الانفعالى : (إعداد الباحثة) وصف البرنامج :

وسوف تعرض الباحثة فى الصفحات القادمة برنامج يمثل تدخلا”Intervention إرشاديا"

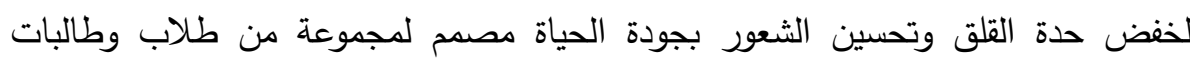

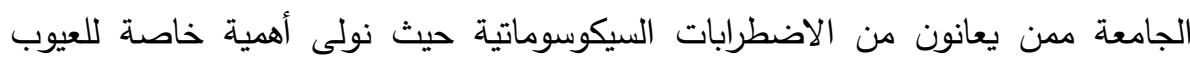

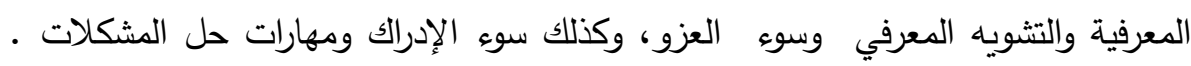

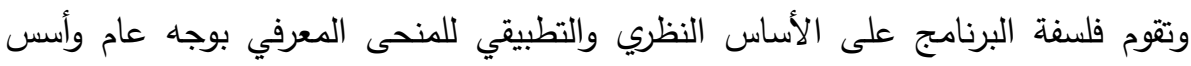

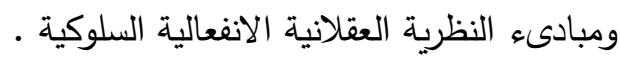

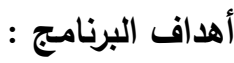

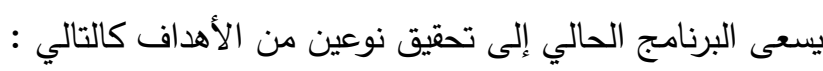

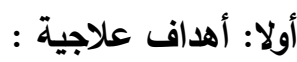
يهدف البرنامج الحالى إلى خفض مشاعر القلق وتحسين الثعور بجودة الحياة لاى طلاب التاب

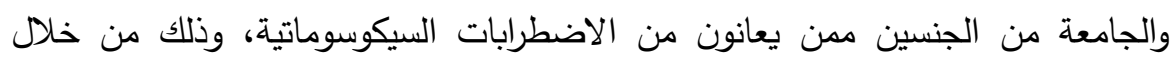

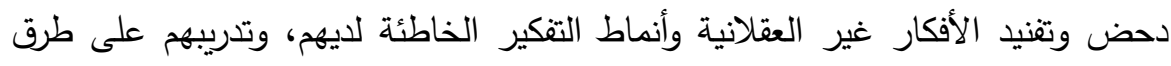

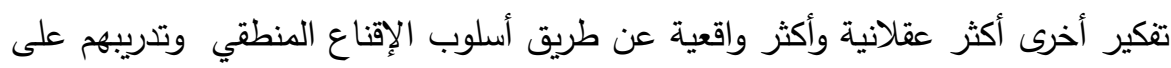

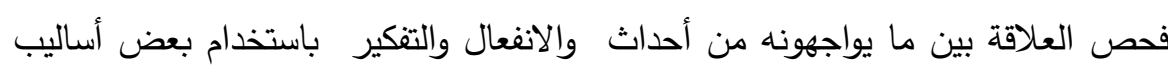

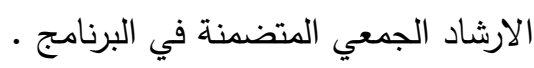

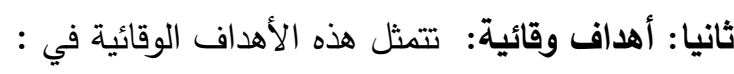

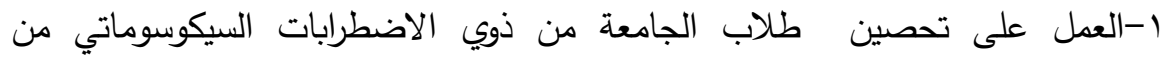

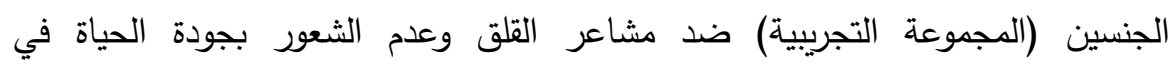

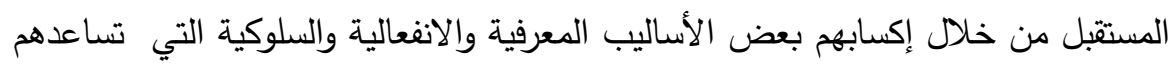

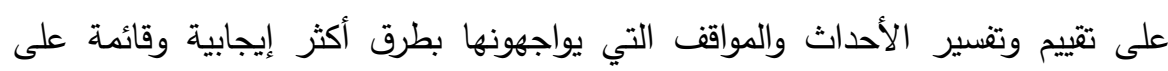

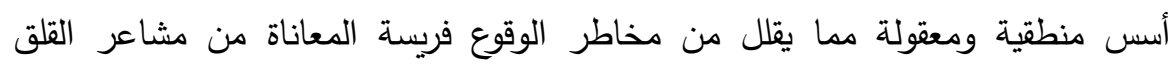

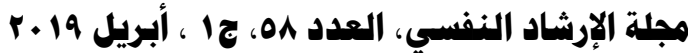


وتحسين مستوى الشعور بجودة الحياة من خلال تدريبهم على ممارسة الفنيات الانفعالية

والسلوكية .

r-تثقيف أفراد المجموعة التجريبية المتلقيين للبرنامج الارشادي عن طريق تزويدهم بمعلومات علمية صحيحة عن أهمية التفكير المنطقي والعقلاني في تتاول الأمور والموضوعات وتقسير الاحداث بدلا من المعلومات المغلوطة الخاطئة وغير اللاعقلانية

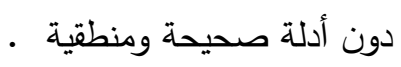

ثالثا" هدف نمائي : من خلال اتاحة الفرصة أمام أفراد المجموعة التجريبية لزيادة

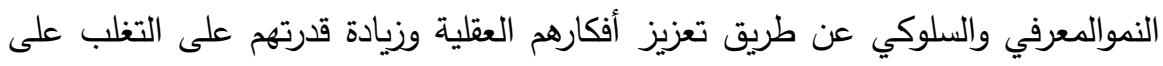
مشاعر القلق وتحسين مستوى شعورهم بجودة الحياة .

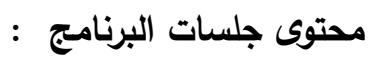

تم اعداد محتوى البرنامج الارشادي من خلال ترتيب جلساته بشكل يتلائم مع طبيعة

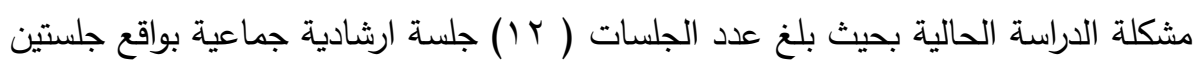

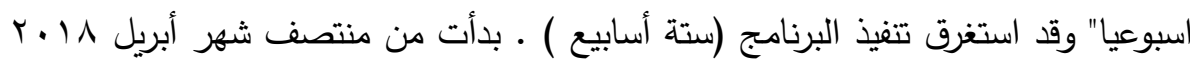

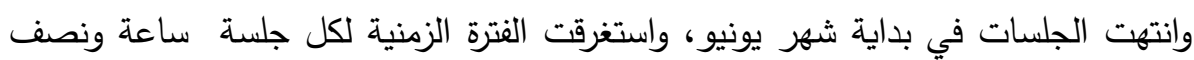

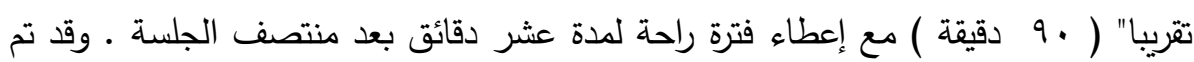

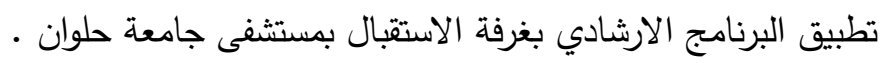
الاراسة الاستطلاعية للبرنامج : للتأكد من ملائمة محنوى البرنامج لأفراد عينة البحث الحالي وتحديد الباديد المشكلات والصعوبات التي قد تتشأ أثناء تطبيق البرنامج قامت الباحثة بدراسة استطلاعية لوحدات

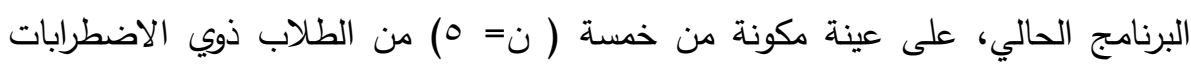
السيكوسوماتية من الجنسين ممن حصلوا على درجات مرتقعة على مقياس القلق، ودرجات

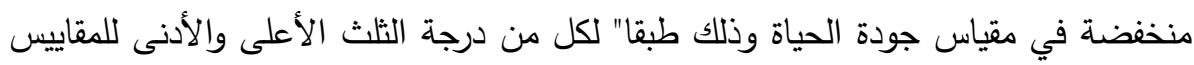

$$
\text { كمعيار لتحديد درجة الاختلالات النفسية . }
$$
كما تم عرض البرنامج على ( ؟) من المحكمين المتخصصين في مجال الصحة النفسية والارشاد النفسي لأبداء الرأي حول البرنامج من حيث مدى صلامل صلاحيته للتطبيق على أفراد

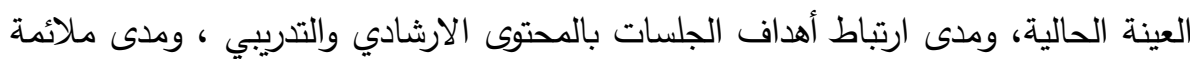

\section{هجلة الإرشاد النفسي، العدد 01، ج1 ، أبريل 19 r r}


الأنشطة والفنيات المستخدمة في الجلسات الارشادية لخصائص عينة البحث، وكذلك مدى

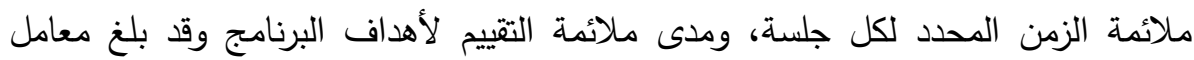

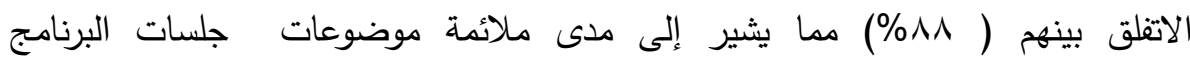
وصلاحيتها للتطبيق على عينة البحث الحالي • والجدول التالي (V) يوضح جلسات البرنامج

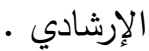

جدول (v)

جلسات البرنامج الارشادي

\begin{tabular}{|c|c|c|c|}
\hline الفنيات المستخدمة & أهداف الجلسة & عنوان الجلسة & رقم \\
\hline 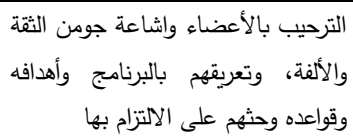 & 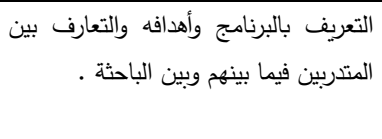 & رف . & -1 \\
\hline 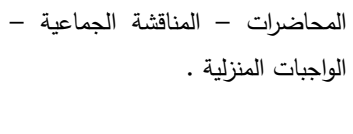 & شالاضطرح مفهوم القلق النفسي وأسبابه وأنواعه الشعور بجودة الحياة وعلاقته & 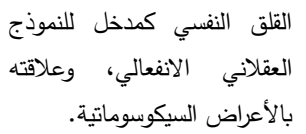 & $-r$ \\
\hline 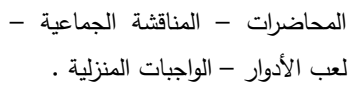 & شرح مفهوم جودة الحياة وعلاقته بالتفكير & مفهوم جودة الحياة & - \\
\hline 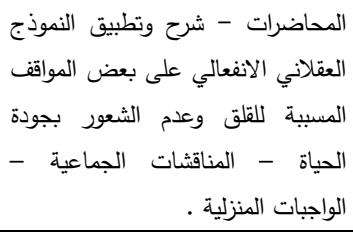 & 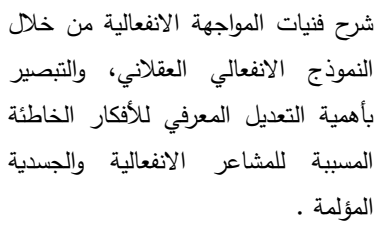 & شرح النظرية العقلانية الانفعالية & $-\varepsilon$ \\
\hline 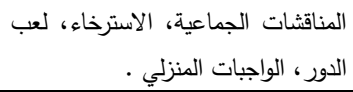 & 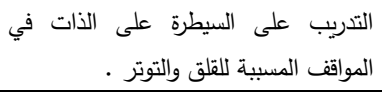 & التدريب على التحكم الذاتي . & -0 \\
\hline 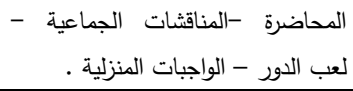 & 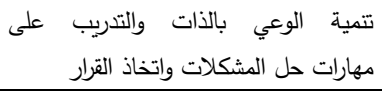 & تتمية مهارات جودة الحياة & -7 \\
\hline 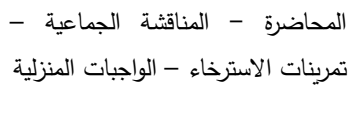 & التُبوربب على تمرينات الاسترخاء للحد من & اكتساب مهارة الاسترخاء & $-v$ \\
\hline 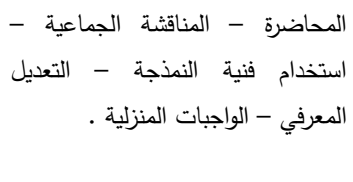 & 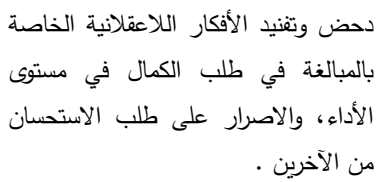 & مناقشة بعض الأفكار اللاعقلانية & $-\wedge$ \\
\hline
\end{tabular}

\section{هجلة الإرشاد النفسي، العدد 01، ج1 ، أبريل 19 r r}




\begin{tabular}{|c|c|c|c|}
\hline 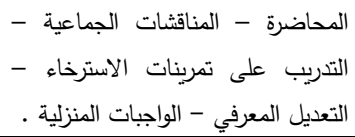 & 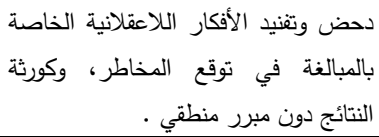 & 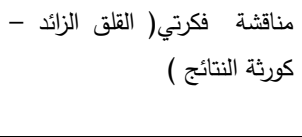 & -9 \\
\hline التعداضل المعرفيل - المناقشات الجماعية - لعب الأدوار - & دتعميم الفشل وتفنيد الفكرة الخاطئة الخاصة & مناقشة وتفنيد فكرة تعميم الفشل . & -1 \\
\hline الواجبات المنزلية . المحاضرة - المنشة- لعب الأدوار - & النفسبير عن الثعور عن السعادة والأمن & النفسي & -11 \\
\hline 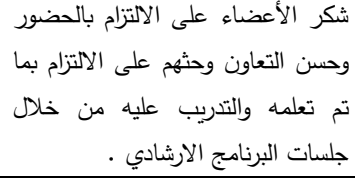 & 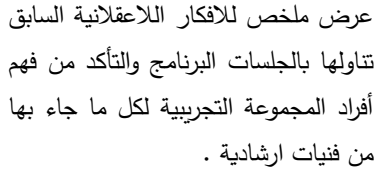 & تلخيص وتقييم البرنامج & $-1 Y$ \\
\hline
\end{tabular}

وبعد تطبيق البرنامج الارشادي على أفراد المجموعة التجريبية قامت الباحثة بتطبيق أدوات الدراسة عليهم ( القياس البعدي) ثم أجرت الباحثة المقارنات بين درجات القياسئين

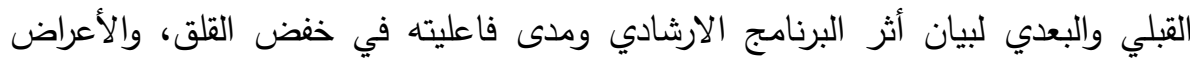

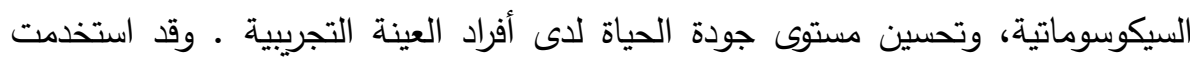
الباحثة لإجراء المقارنة الاحصائية بين القياسيين القبلي والبعدي إختبار ويلكوكسون اللابارمتري Wilcoxon,T للتعرف على دلالة الفروق بين المتوسطات الحسابية لأفراد

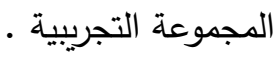

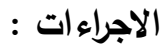

تم تطبيق المقاييس المستخدمة في البحث بصورة جماعية على أفراد العينة بعد قراءة

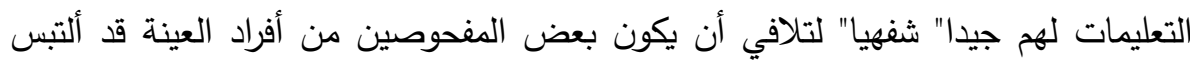

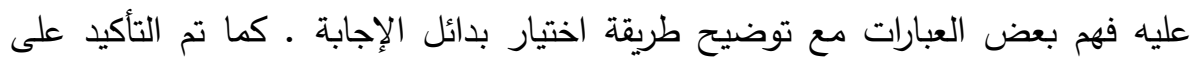
الاجابة في كل عبارة على حدة، والتأكيد عليهم بعدم ترك أي عبارة دون اجابة، وتوضيح

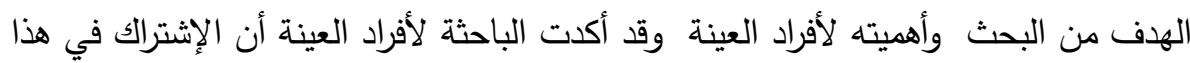

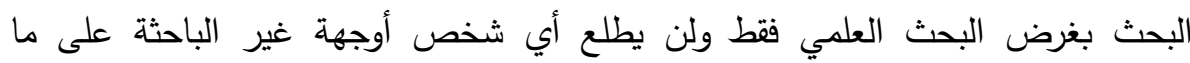
سيتضمنه من بيانات ـ كما حرصت الباحثة على التأكد من مله استمارة البيانات الثخصية • وقد تم تطبيق المقاييس المستخدمة في البحث وفقا" للترتيب التالي :

\section{هجلة الإرشاد النفسي، العدد 01، ج1 ، أبريل 19 r r}




$$
\begin{aligned}
& \text { 1- استمارة جمع البيانات . } \\
& \text { r- بائمة " كورنل " للأعراض السيكوسوماتية . ل }
\end{aligned}
$$

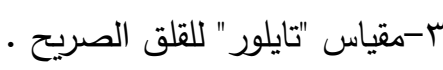

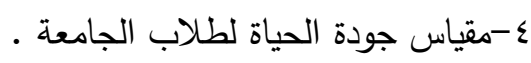

$$
\begin{aligned}
& \text { ه-البرنامج الارشادي العقلاني الانفعالي . }
\end{aligned}
$$

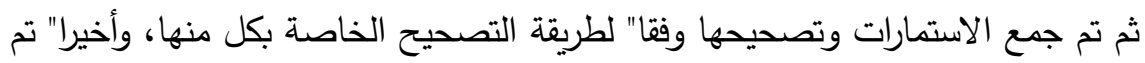

جدولة النتائج وذلك للقيام بمعالجتها احصائيا" .

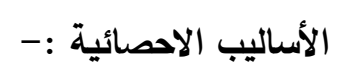

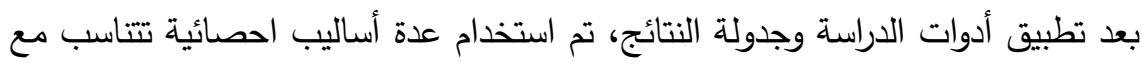

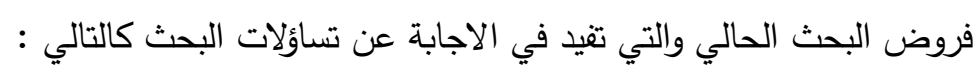

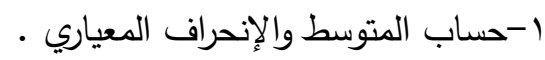

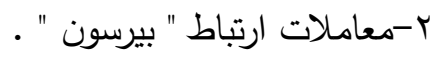

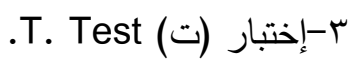

ع-اختبار مان ويتني Mann-Whitney U للعينات الصغيرة لحساب دلالة الفروق بين

$$
\text { المجموعتين التجريبية والضابطة مانيان }
$$

ه-اختبار ويلكسوكون W اللابارمترى للمجموعات المرتبطة للتعرف على دلالة الفروق بين

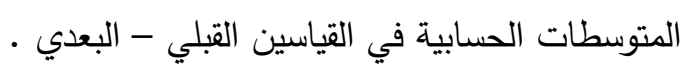

وبالإنتهاء من الحديث عن أدوات وإجراءات الدراسة، ستقوم الباحثة بعرض ومناقشة

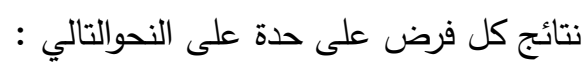

\section{نتائج الدراسة وهناقشتها :}

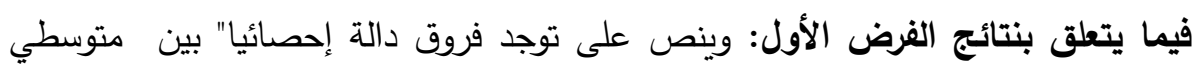

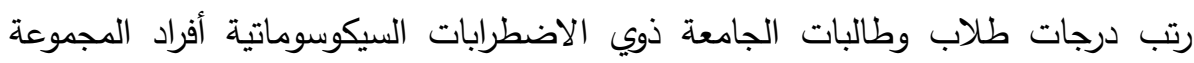

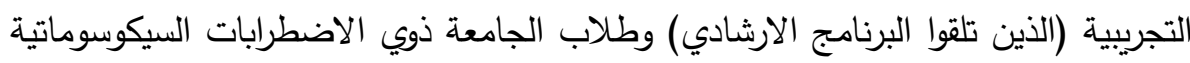

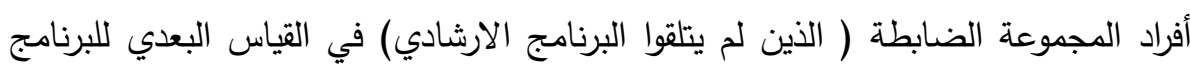

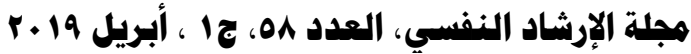


في كل من مقياسي التلق الصريح،وجودة الحياة لطلاب الجامعة، وقائمة "كورنل" للأعراض

السيكوسوماتية. وللتحقق من صحة هذا الفرض قامت الباحثة بخطوتين هما :

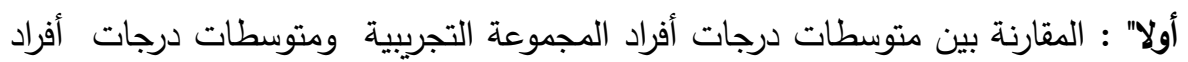
المجموعة الضابطة في المقاييس الفرعية والدرجة الكلية لمتغيرات الدراسة في القياس القبلي لتطبيق البرنامج لكل من مقياس القلق الصريح ومقياس جودة الحياة لطلاب الجامعة باستخدام مقياس اختبار مان ويتتي (ي) Mann- Whitney. U. Test كما يوضحه

جدول (^)

دلالة الفروق بين متوسطات درجات أفراد المجموعتين التجريبية والضابطة في متغيرات الدراسة في القياس التبلي لتطبيق البرنامج

\begin{tabular}{|c|c|c|c|c|c|c|}
\hline \multirow{2}{*}{ مستوى الدلالة } & \multirow{2}{*}{ قالمة U U } & \multirow[b]{2}{*}{ U2 } & \multirow{2}{*}{10} & الضابطة المجوعة & التجريبية & \multirow[b]{2}{*}{ المتغيرات } \\
\hline & & & & 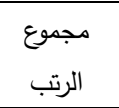 & مجموع & \\
\hline غير دال & $\cdot, 9 \vee$ & זי & 07 & $17 r$ & ITV & 1-القلق الصريح · \\
\hline \multirow[b]{2}{*}{ 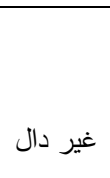 } & \multirow[b]{2}{*}{$1, \varepsilon \leqslant$} & \multirow[b]{2}{*}{ Vr } & \multirow[b]{2}{*}{1.0} & \multirow[b]{2}{*}{$|r|$} & \multirow[b]{2}{*}{110} & الجامعة . ل \\
\hline & & & & & & أ-جودة الحياة الاجتماعية . \\
\hline غير دال & $1,7 V$ & 70 & $1 \cdot v$ & 1.9 & 114 & ب-جودة الحياة المادية . \\
\hline غير دال &,$\wedge$ & $1 \ldots$ & 91 & IrE & 111 & ج-جودة الحياة الوجدانية . \\
\hline 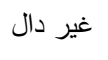 & $1, v \leqslant$ & $1 \cdot r$ & 114 & Mr & 117 & د- جودة الحياة الاكاديمية . \\
\hline غير دال & $1, \vee \wedge$ & $1 . r$ & 111 & 119 & Mr & هـ - الرضا عن الحياة . \\
\hline غير دال & l,Ar & $\varepsilon$. & $\varepsilon r$ & int & ror & الدرجة الكلية \\
\hline \multirow[b]{2}{*}{ غير دال } & \multirow[b]{2}{*}{, } & \multirow[b]{2}{*}{$\wedge 9$} & \multirow[b]{2}{*}{01} & \multirow[b]{2}{*}{117} & \multirow[b]{2}{*}{$11 \varepsilon$} & r ب-قائمة "كورنل" للأعراض \\
\hline & & & & & & 1-الجهاز التتفسي · \\
\hline غير دال & $1, \times 7$ & 11. & ro & 111 & 114 & r-الجهاز الهضدي . \\
\hline 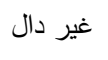 & $1, \wedge \varepsilon$ & 1.7 & 115 & 110 & $11 \mathrm{~V}$ & r-القلب والأوعية . \\
\hline غير دال & $1, v r$ & $\varepsilon 7$ & $\varepsilon \varepsilon$ & rus & rTV & الدرجة الكلية \\
\hline
\end{tabular}




$$
\begin{aligned}
& \text { "قيمة "U" الجدولية = } 97
\end{aligned}
$$

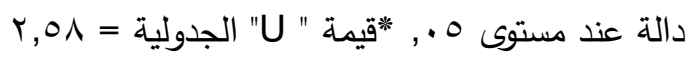

$$
\begin{aligned}
& \text { دالة عند مستوى 1. } \\
& \text { ويتضح من جدول (^) ما يلي : }
\end{aligned}
$$

*لا توجد فروق دالة احصائيا" بين متوسطات درجات أفراد المجموعة التجريبية وأفراد

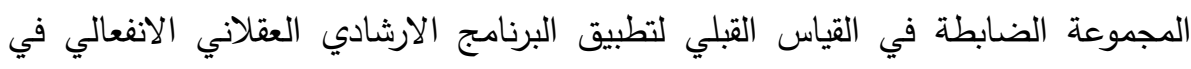

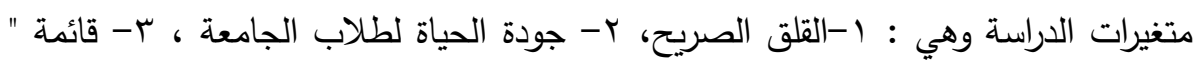
كورنل" للأعراض السيكوسوماتية . ثانيا" : المقارنة بين متوسطات درجات أفراد المجموعة التجريبية ومتوسطات درجات أفراد المجموعة الضابطة في المقاييس الفرعية والدرجة الكلية لمتغيرات الدراسة في القياسين البعدي لتطبيق البرنامج على أفراد المجموعة التجريبية لكل من مقياس القلق الصريح

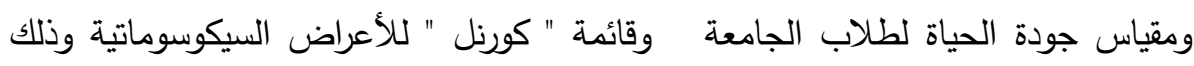
باستخدام مقياس اختبار مان ويتني (ي) Mann- Whitney. U. Test كما يوضحه جدول (9) : (9) : (9) جدول (9)

\begin{tabular}{|c|c|c|c|c|c|c|}
\hline \multicolumn{7}{|c|}{ لتطبيق البرنامج } \\
\hline \multirow{5}{*}{ الدلالة } & \multirow{5}{*}{$\begin{array}{l}\text { ق قيمة U } \\
\text { المحسوبة }\end{array}$} & \multirow{5}{*}{$\mathrm{U} 2$} & \multirow{5}{*}{10} & المجموعة & المجموعة & \multirow{5}{*}{ المتغيرات } \\
\hline & & & & الضابطة & التجريبية & \\
\hline & & & & ن =ن & ن & \\
\hline & & & & مجموع & مجموع & \\
\hline & & & & الرتب & 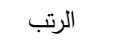 & \\
\hline \multirow[t]{2}{*}{, .0} & r, tr & $\wedge \mathrm{V}$ & re & 179 & rro & 1-القلق الصريح • \\
\hline & & & & \multirow[b]{2}{*}{$11 \mathrm{~V}$} & \multirow[b]{2}{*}{150} & ץ-جودة الحياة لطلاب الجامعة . \\
\hline, .0 & $1,9 \leqslant$ & VY & 1.0 & & & أ-جودة الحياة الاجتماعية . \\
\hline,$\cdot 1$ & r,TV & 10 & $1 \cdot v$ & 90 & irA & ب-جودة الحياة المادية . \\
\hline, .1 & $r, \wedge$. & 91 & ir. & $1 \cdot r$ & IrT & ج-جودة الحياة الوجدانية . \\
\hline, .0 & $r, I V$ & $1 . r$ & $14 \mathrm{r}$ & AV & ITr & د- جودة الحياة الاكاديمية . \\
\hline,$\cdot 1$ & r,YA & $1 . r$ & $|r|$ & 94 & $1 \leqslant 0$ & هـ - الرضا عن الحياة . \\
\hline, .1 & $r, \pi r$ & rr & $\varepsilon r$ & Irr & 100 & الدرجة الكلية \\
\hline
\end{tabular}
دلالة الفروق بين متوسطات رتب درجات أفراد المجموعتين التجريبية والضابطة في متغيرات الدراسة في القياس البعدي 


\section{فاعلية برناهج ارشادي عقلاني انفعالي لخفض أعراض القلق وتصسين جودة الحياة}

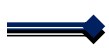

\begin{tabular}{|c|c|c|c|c|c|c|}
\hline & & & & & & r- -قائمة " كورنل" للأعراض \\
\hline., 1 & 1,74 & 11. & זr & 11. & 70 & \\
\hline,., 1 & $r, O V$ & ع & 90 & 1.0 & TV & \\
\hline., 1 & rז,r & qV & $\varepsilon r$ & הr & $\leq 7$ & \\
\hline., 1 & $r, 09$ & $\varepsilon r$ & ז & 100 & 97 & \\
\hline & & & & & & 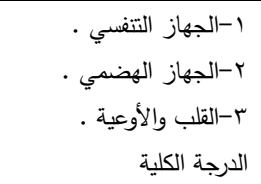 \\
\hline
\end{tabular}

دالة عند مستوى 0 . ,

1,97 = قيمة "U" الجدولية"

- دالة عند مستوى

r,Oᄉ = قيمة " الجدولية" ويتضح من جدول (9) ما يلي :

ا-توجد فروق دالة احصائيا" عند مستوى ( ه. ., · ·) بين متوسطي رتب درجات أفراد المجموعة التجريبية وأفراد المجموعة الضابطة في القياس البعدي لتطبيق البرنامج على دلى دئي

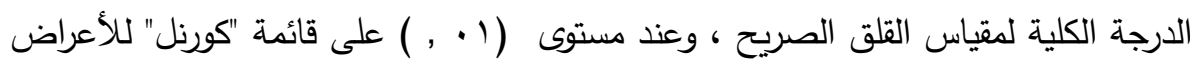

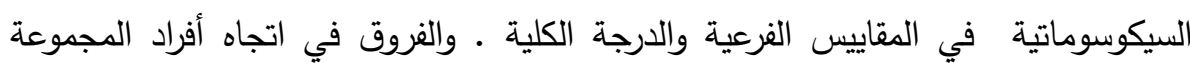
الضابطة .

Y-توجد فروق دالة احصائيا" عند مستوى ( ( •, • ) بين متوسطي رتب درجات أفراد

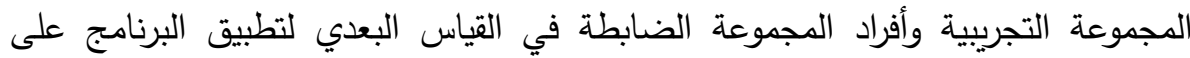

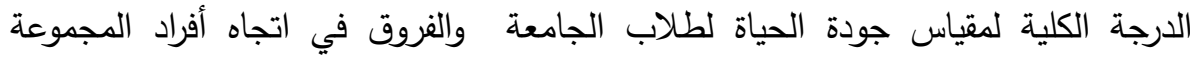
التجريبية، وعند مستوى ( 0., •) للمقايسين الفرعيين ( جودة الحياة الاجتماعية، وجودة

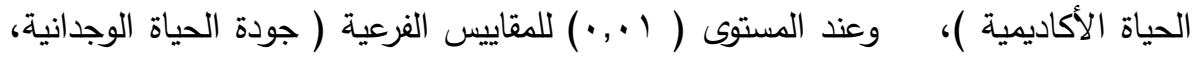
جودة الحياة المادية، والرضا عن الحياة ) • والفروق في اتجاه المجموعة التجريبية .

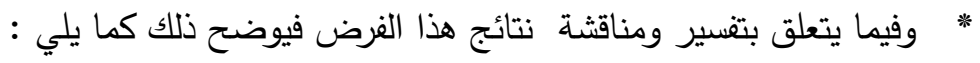

أولا" : بالنسبة لمقياس القلق الصريح ، وقائمة " كورنل" للأعراض السيكوسوماتية : فتعني تلك النتائج تحسن أفراد المجموعة التجريبية التي تلقت البرنامج الارشادي العقلاني

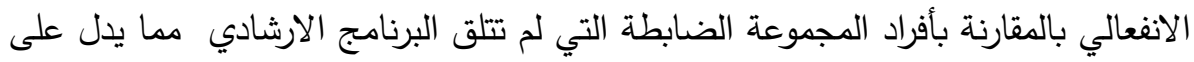

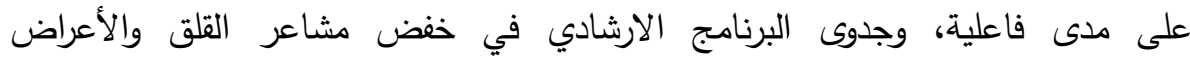

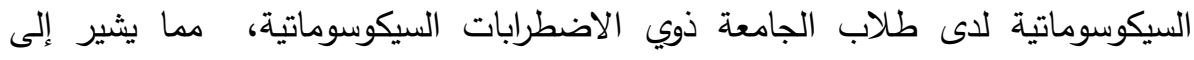

\section{هجلة الإرشاد النفسي، العدد 01، ج1 ، أبريل 19 r r}


استفادة أفراد المجموعة التجريبية المتعرضين للبرنامج من الاستراتيجيات والفنيات الارشادية

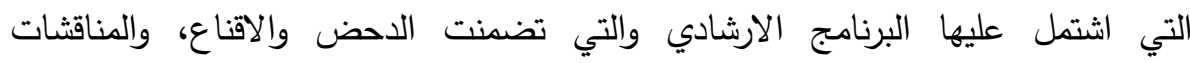
الجماعية، والواجبات المنزلية، وتتمية مهارات التعامل مع مصادر القلق والتهديد، وتدريبهم

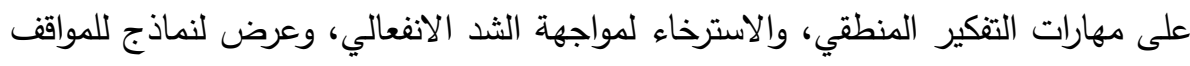

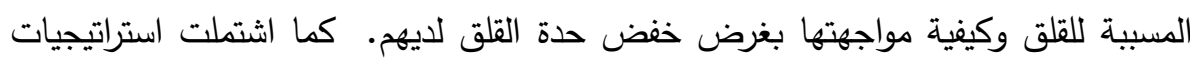

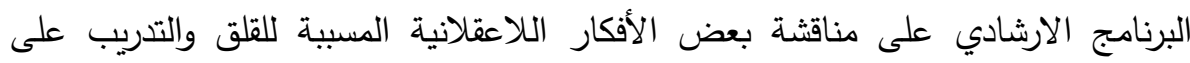

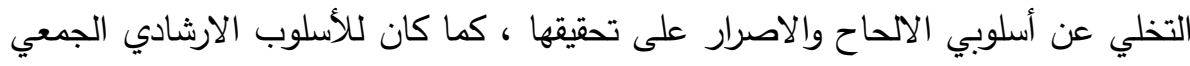

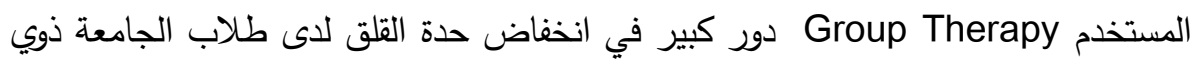
الاضطرابات السيكوسوماتية حيث ساعد استخدام الارشاد الجمعي على مناقشة المشكلات

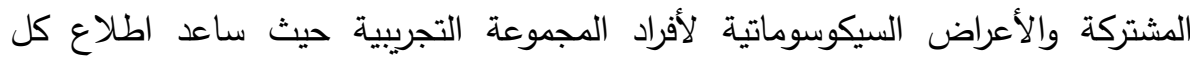

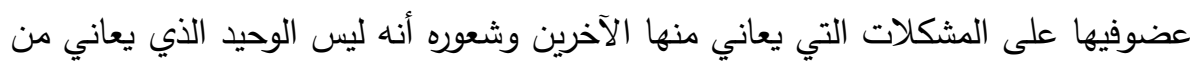

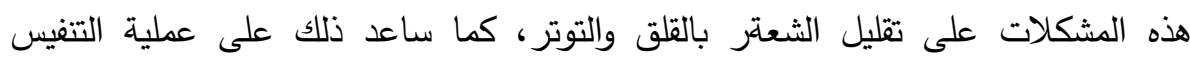

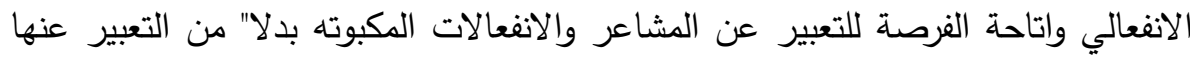

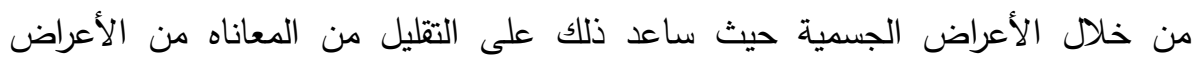

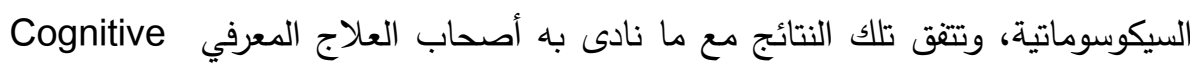

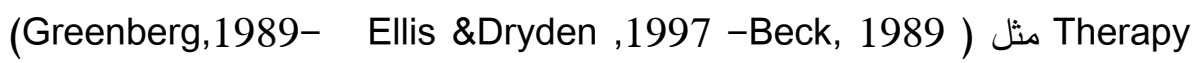
Ellis,1990والمعتقدات اللاعقلانية وأن نوعية نسق التفكير عن الاحداث التي يواجهها تلعب دورا"

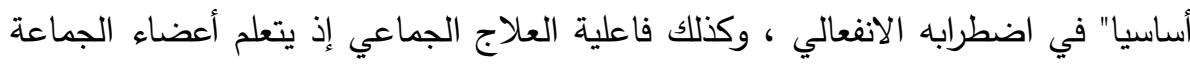

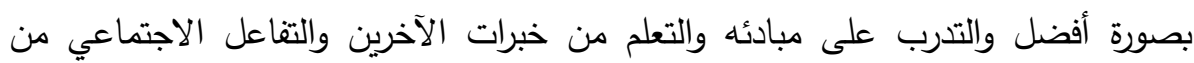

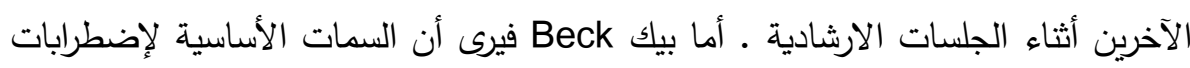

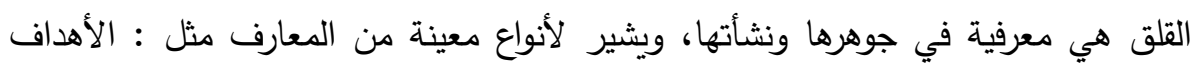

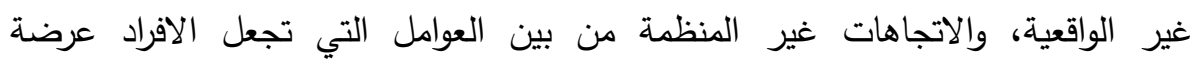

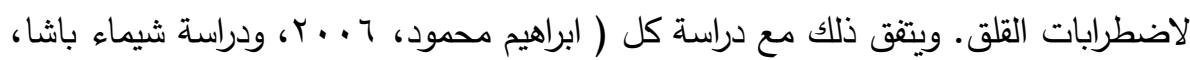

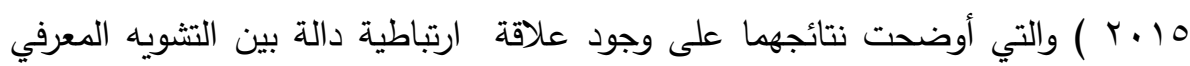
ومشاعر الققى، وفاعلية الارشاد العقلاني الانفعالي في خفض قلق المستقبل ـ. ويذكر

\section{هجلة الإرشاد النفسي، العدد 01، ج1 ، أبريل 19 r r}


(باترسون، •199 : 19 أن نجاح الفرد في التخلص من المشاعر المؤلمة نفيا" وخاصة القلق يتوقف بشكل أساسي على تصحيح التصورات الخاطئة والافتراضات المضللة والأفكار المشوهة .

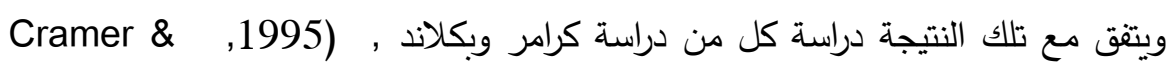

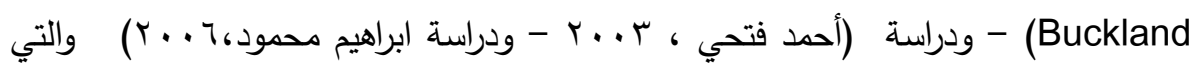

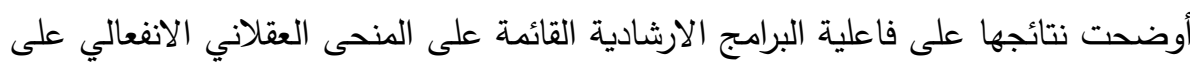

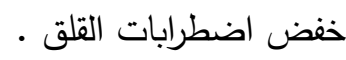
كما تعرض البرنامج الارشادي إلى شرح وتوضيح العلاقة بين القلق والاضطرابات السيكوسوماتية حيث أوضحت العديد من الدراسات وجود ارتباط دال وموجب بين التوتر والقلق والأعراض جسمية مرضية، وأن هذه الأعراض المرضية في حال استمرارها تسبب

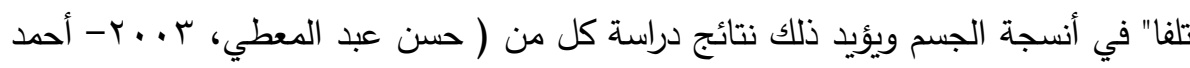

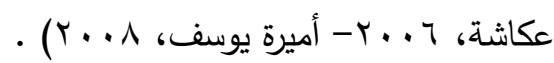

ثانيا" : بالنسبة لمقياس جودة الحياة لطلاب الجامعة : فتعني تلك النتائج تحسن أفراد المجموعة التجريبية التي تلقت البرنامج الارشادي العقلاني الانفعالي بالمقارنة بأفراد

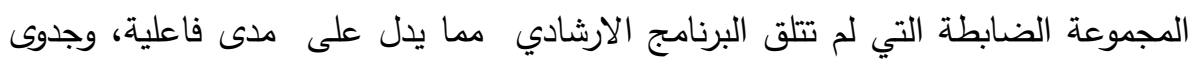

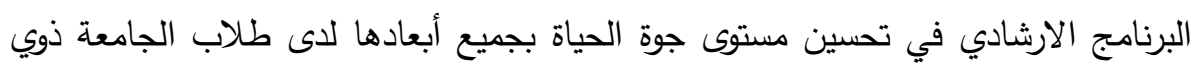

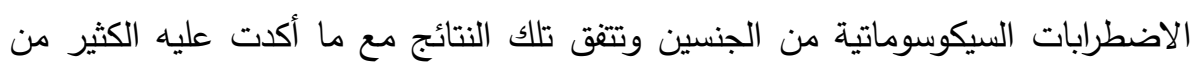

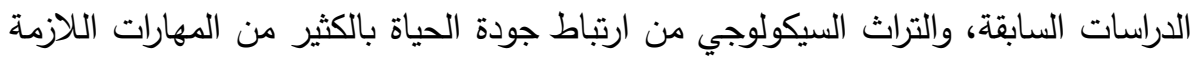

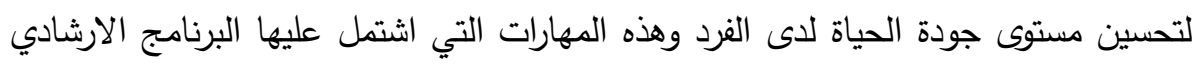
المستخدم في البحث الحالي ومن أهمها تصحيح ادراكات الفرد وتدريبه على أساليب

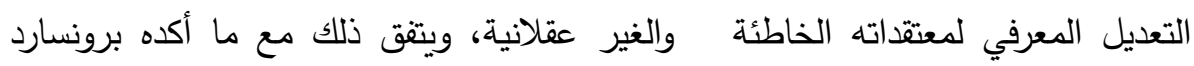
وآخرون (2013, . Bronsared et al) في أن جودة الحياة هي كافة المجالات المادية والنفية والاجتماعية والصحية التي يتم تقييمها وادراكها بناء على توقعات ومعتقدات الفرد .

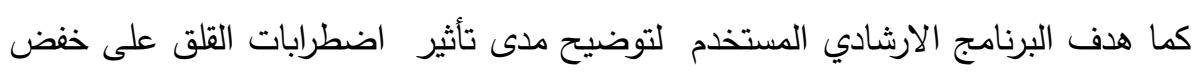

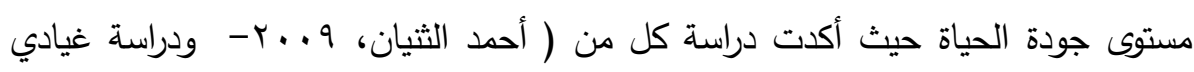

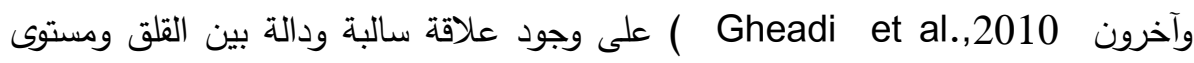

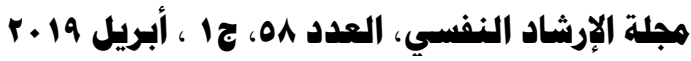




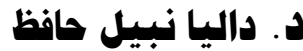

جودة الحياة بأبعادها المختلفة، وتضمن البرنامج استراتيجيات حل المشكلة والتحكم الذاتي في الانفعالات وهي كلها مهارات لازمة لتحسين جودة الحياة لاى الفرد ويتقق ذلك مع نتائج

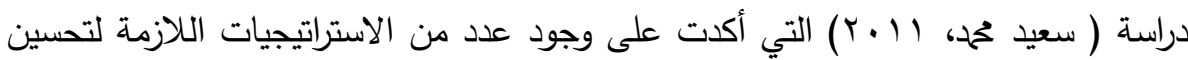

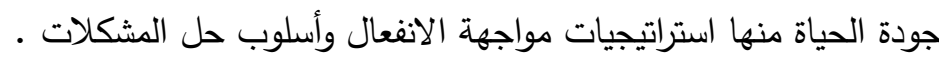

كذلك ارتكز محتوى البرنامج الارشادي على تتمية ثقافة الحوار والدافعية ومهارات

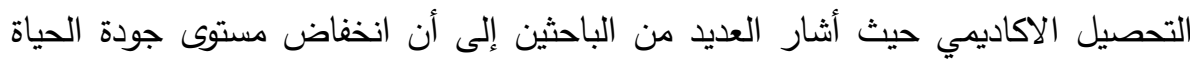

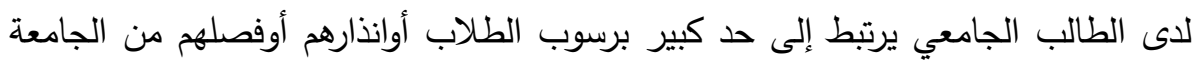

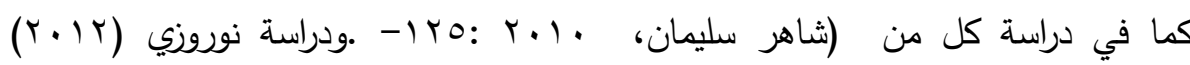
- Norouzi ودالة بين جودة الحياة وتتمية ثثلفة الحوار والدافعية للإنجاز والتقوق الأكاديمي لدى طلاب

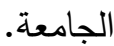

كما اشتمل مضمون البرنامج الارشادي المستخدم على شرح العلاقة بين انخفاض مستوى شعور الفرد بالرضا عن ذاته وحياته وعلاقته بالآخرين والذي يسبب بشكل أساسي انخفاض جودة الحياة لدية وبين اضطراب وظائفه الجسمسة وما يعاني من من مشكلات

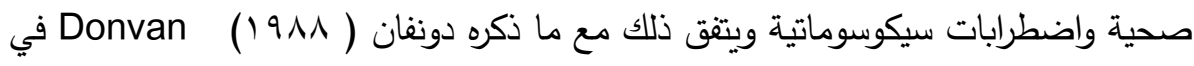

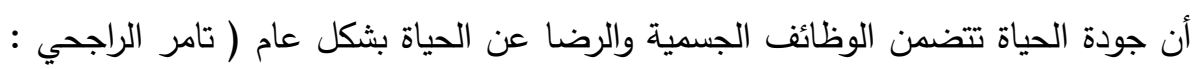

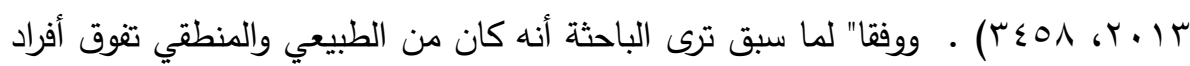

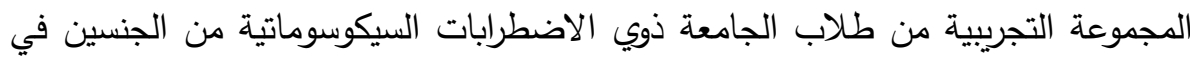

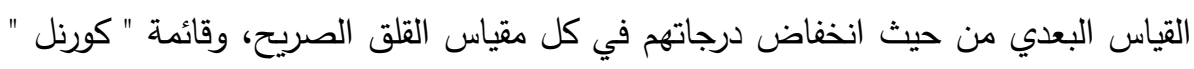

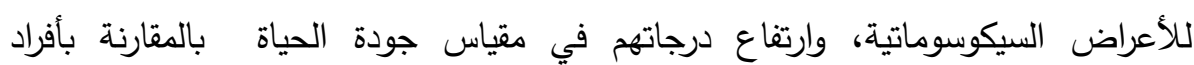

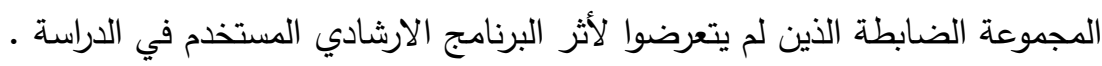

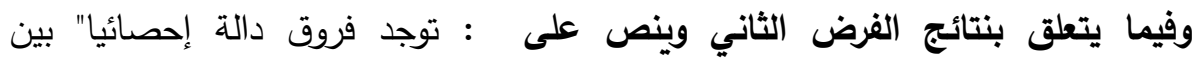
متوسطات رتب درجات طلاب وطالبات الجامعة ذوي الاضطرابات السيكوسوماتية أفراد المجموعة التجريبية في القياس القبلي ومتوسطات رتب درجاتهم في القياس البعدي للبرنامج

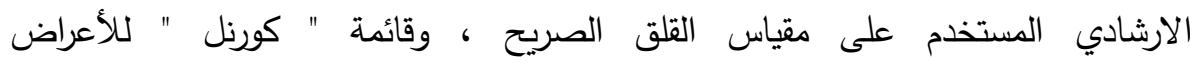

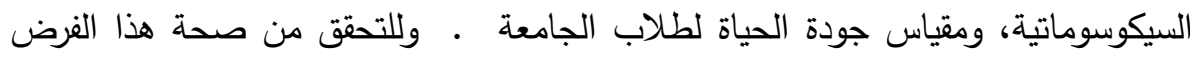

\section{هجلة الإرشاد النفسي، العدد 01، ج1 ، أبريل 19 r r}


قامت الباحثة بالمقارنة بين متوسطي رتب درجات أفراد المجموعة التجريبية في القياسين

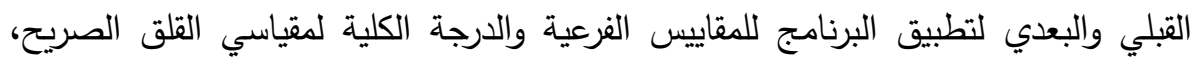
وجودة الحياة لطلاب الجامعة وقائمة " كورنل " للأعراض السيكوسوماتية ـ وذلك بإستخدام اختبار ويلكوكسون اللابارمتري Wilcoxon (W) لحساب دلالة الفروق بين المتوسطات الحسابيى لأفراد المجموعة التجريبية كما يوضحه جدول (· • (1) كما يلي : جدول (·) (1)

دلالة الفروق بين متوسطات رتب درجات أفراد المجموعة التجريبية في متغيرات الدراسة في كل من القياسين القبلي

\begin{tabular}{|c|c|c|c|c|c|c|c|c|}
\hline \multirow[b]{2}{*}{ مستوى } & \multirow[b]{2}{*}{$\begin{array}{l}\text { قيمة } \\
Z\end{array}$} & \multicolumn{2}{|c|}{ مجموع الرتب } & \multicolumn{2}{|c|}{ متوسط الرتب } & \multirow[b]{2}{*}{ ن } & \multirow[b]{2}{*}{ القياس } & \multirow{2}{*}{ المجموعة التجريبية } \\
\hline & & الموجبة & السالبة & الموجبة & السالبة & & & \\
\hline \multirow[t]{2}{*}{., .0} & $r, 1 \varepsilon$ & $1 \cdot \varepsilon, 0$ & 0,0 & $\varepsilon, r T$ & $9, \wedge \wedge$ & ir & قبلي - بعدي & 1-القلق الصريح . \\
\hline & & & & & & \multirow[b]{2}{*}{ Ir } & \multirow{2}{*}{ قبلي - بعدي } & ז-جودة الحياة . \\
\hline, .0 & $r, r_{0}$ & $11 r, 0$ & 9,00 & $1 \cdot, 11$ & T,or & & & \multirow{6}{*}{ 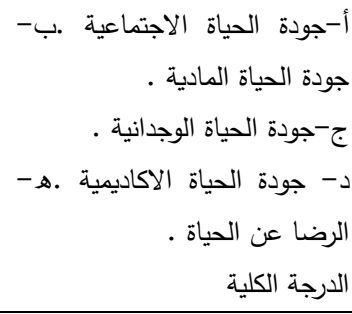 } \\
\hline, .0 & $r, r$. & 19 & 7 & $V, \varepsilon Y$ & $\{, 0 \leqslant$ & Ir & قبلي - بعدي & \\
\hline, .1 & $r, 09$ & 119 & $\wedge$ & $11, \varepsilon r$ & $7, r \varepsilon$ & ir & قبلي - بعدي & \\
\hline, .0 & $r, r_{1}$ & 1.0 & Tr, & $9,0 \leqslant$ & $0, \varepsilon r$ & ir & قبلي - بعدي & \\
\hline, .1 & $r, \pi$ & $9 \wedge$ & $\varepsilon, Y_{O}$ & $0, \leqslant r$ & I,r & ir & قبلي - بعدي & \\
\hline,$\cdot 1$ & r,, 0 & $1 \cdot r, 0$. & $1 \cdot, 0$ & $1 \varepsilon, r_{0}$ & $v, r \varepsilon$ & ir & قبلي - بعدي & \\
\hline \multirow[b]{2}{*}{, .0} & \multirow[b]{2}{*}{$r, r$. } & \multirow[b]{2}{*}{$11 K, 0$} & \multirow[b]{2}{*}{$V, \leq 0$} & \multirow[b]{2}{*}{$\varepsilon, Y Y$} & \multirow[b]{2}{*}{0,07} & \multirow[b]{2}{*}{ ir } & \multirow[b]{2}{*}{ قبلي- بعدي } & الس-قائمة "كورنل" للأعراض \\
\hline & & & & & & & & ا-الجهاز التتفسي • \\
\hline, .0 & $r, 97$ & $V \varepsilon$ & r & $V, \varepsilon r$ & $\varepsilon, 7 \varepsilon$ & ir & قبلي - بعدي & ץ-الجهاز الهضمي • \\
\hline, .0 & $r, \cdot v$ & 19 & r & $\wedge, 01$ & $v, 0$ & ir & قبلي - بعدي & r-القلب والأوعية . \\
\hline, .0 & $r, 70$ & $1.0,11$ & $r, 0$. & ט & $T, Y V$ & ir & قبلي -بعدي & الدرجة الكلية . \\
\hline
\end{tabular}

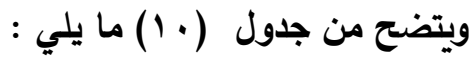

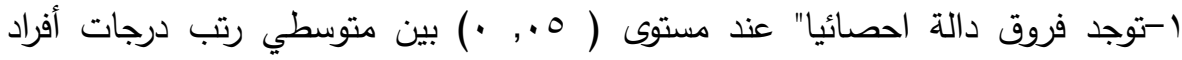
المجموعة التجريبية في القياسين القبلي والبعدي لتطبيق البرنامج على الدرجة الكلية،

\section{هجلة الإرشاد النفسي، العدد 01، ج1 ، أبريل 19 ب r}




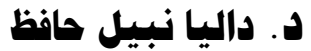

لدقياس القاق الصريح. والدقاييس الفرعية والدرجة الكلية لقائمة "كورنل" للأعراض

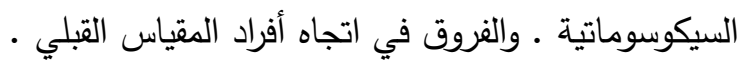

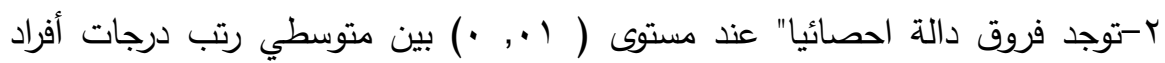
المجموعة التجريبية في القياسين القبلي والبعدي لتطبيق البرنامج على الدرجة الكلية لدياس

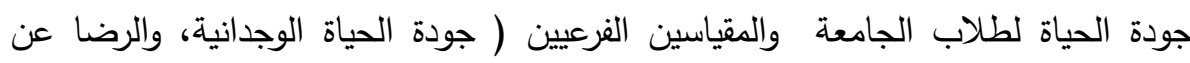

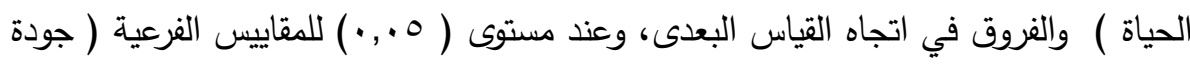

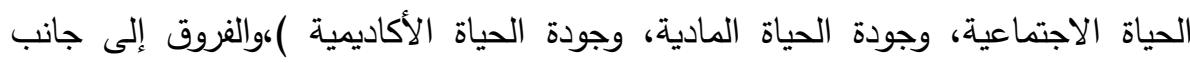

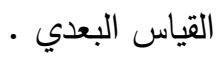
وقد تحقق الفرض السابق حيث أشارت نتيجته لوجود فروق دالة احصائيا" بين

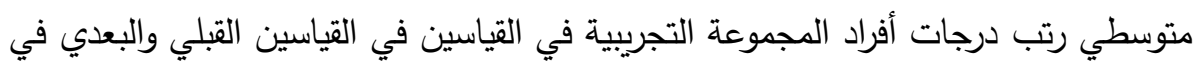

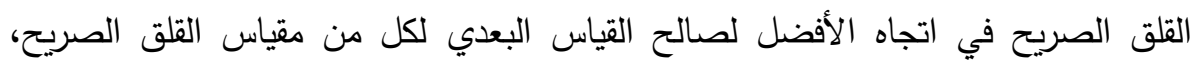

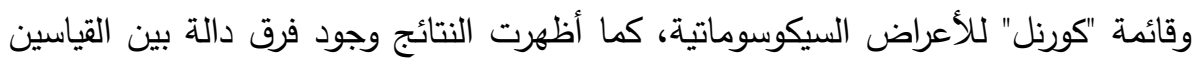

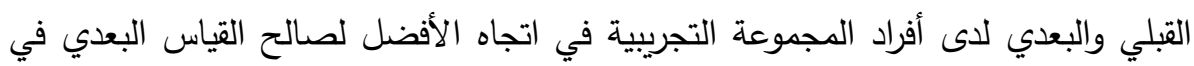

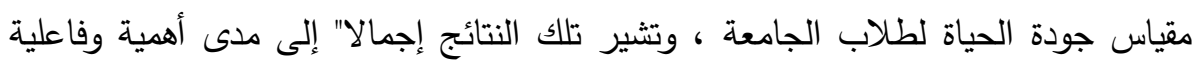

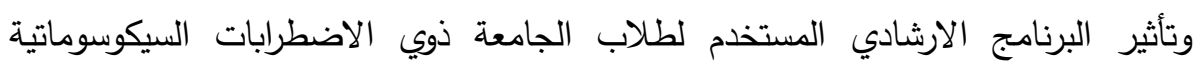
ويهذف لخفض القلق وتحسين جودة الحياة لليهم من خلال العادة البنية المعرفية بالتعديل المعرفي لأفكارهم اللاعقلانية المتقتدين فيها والخاصة بطبيعة إدراكهم وتقييمهم لذاتواتهم

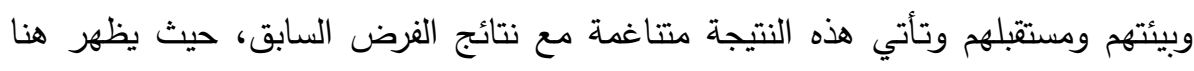

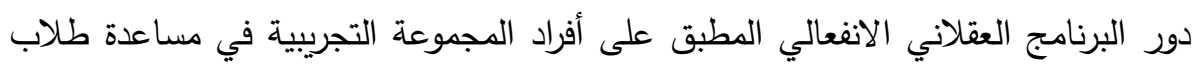

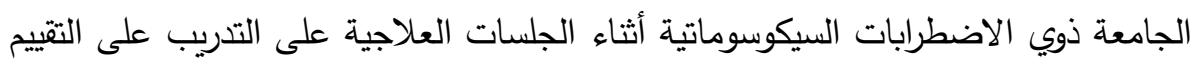

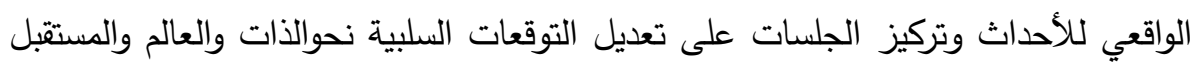

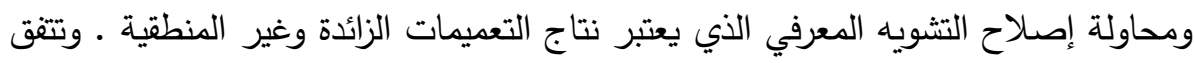

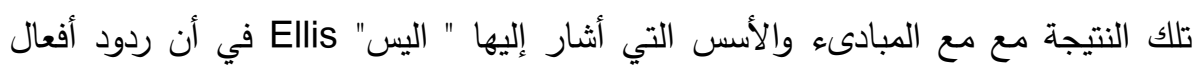

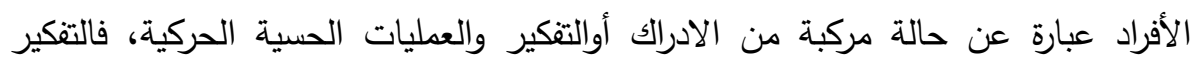
والانفعال لا يمثلان عمليتان منفصلتان .ويتقق ذلك مع ما أكده (2013) Bronsared et 
من أن جودة الحياة هي كافة المجالات المادية والنفسية والاجتماعية والصحية ويتم

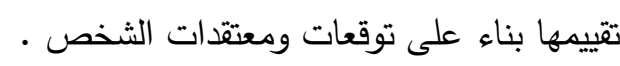

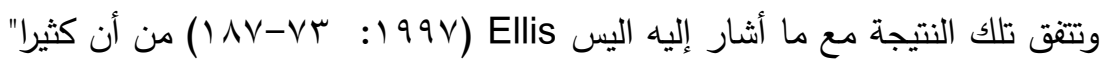
من الاضطرابات النفسية تتكون من فعل توقعاتتا اللاعقلانية وغير الواقعية فالأفكار

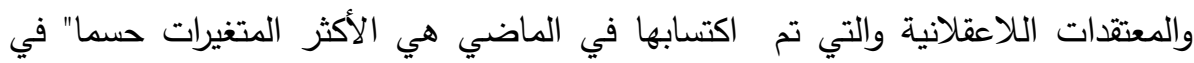
احداث الاضطرابات النفسية. فالفرد يسلك وفق تصوره مسبقا" وبالتالي يقع فريسة

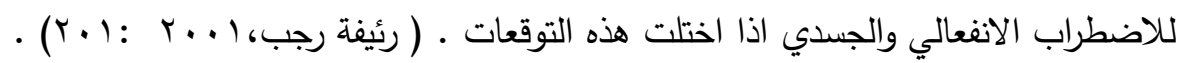
كما جاءت هذه النتيجة منطقية وفقا لما قامت به الباحثة سابقا من اجرءات لإتمام المجانسة بين المجموعتين التجريبية والضابطة في بعض المتغيرات التي من شأنها أن تزيد من المعاناة الانفعالية من القلق والأعراض السيكوسوماتية، وانخفاض مستوى جودة لينه الحياة لدى طلالب الجامعة ذوي الاضطرابات السيكوسوماتية مثل ( العمر - المستوى الاجتماعي الاقتصادي) ومن ثم فإن ظهور فروق دالة احصائيا" بين القياسين القبلي والبعدي من تطبيق البرنامج لدى أفراد المجموعة التجربيية قد يرجع فقط إلى تأثير وفاعلية

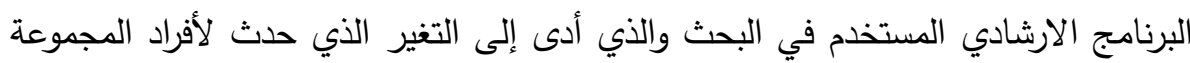

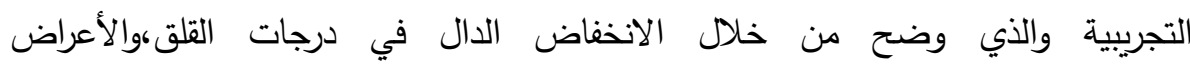

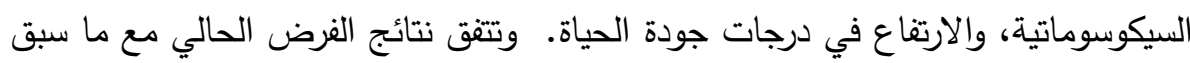

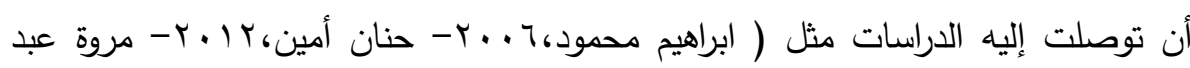

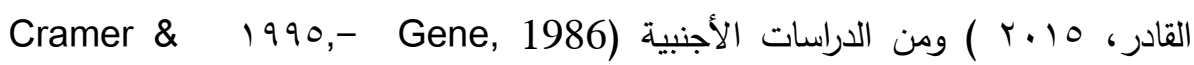
) حيث أكدت نتائجها على الدور الفعال للبرامج الارشادية والعلاجية القائمة على المنحى المعرفي والعقلاني الانفعالي في زيادة

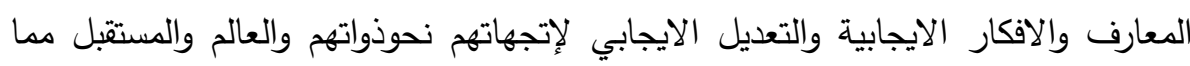
ينعكس بدوره ايجابيا" على تحسين مستوى جودة الحياة لديهم، وخفض معاناتهم من

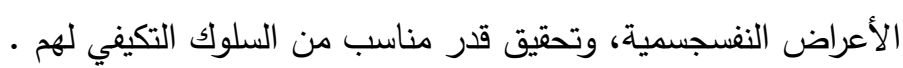
وفيما يتعلق بنتائج الفرض الثالث وينص على: - لا توجد فروق دالة إحصائيا" بين متوسطات رتب درجات أفراد المجموعة التجريبية في القياسين البعدي والتتبعي لتطبيق 
البرنامج في كل من مقياس القلق الصريح، وقائمة " كورنل " للأعراض السيكوسوماتية،

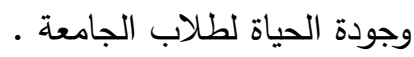

وللتحقق من صحة هذا الفرض قامت الباحثة بالمقارنة بين متوسطي رتب درجات أفراد المجموعة الضابطة في القياسين البعدي والتتبعي لتطبيق البرنامج للمقاييس الفرعية والدرجة

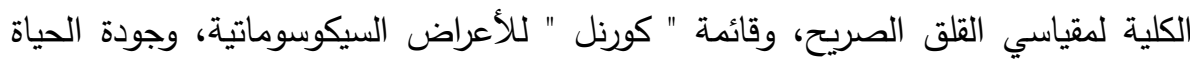

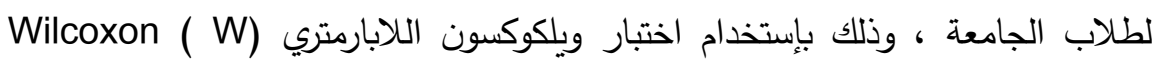
لحساب دلالة الفروق بين المتوسطات الحسابيى لأفراد المجموعة التجريبية كما يوضحه

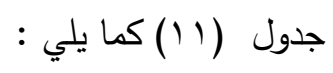

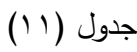

دلالة الفروق بين متوسطات المجموعة التجريبية في متغيرات الدراسة في كل من القياسين البعدي والتتبعي

\begin{tabular}{|c|c|c|c|c|c|c|c|c|}
\hline \multirow[b]{2}{*}{ مستوى الدلالة } & \multirow[b]{2}{*}{$\begin{array}{r}\text { قيمة } \\
Z\end{array}$} & \multicolumn{2}{|c|}{ مجموع الرتب } & \multicolumn{2}{|c|}{ متوسط الرتب } & \multirow[b]{2}{*}{$\dot{~}$} & \multirow[b]{2}{*}{ 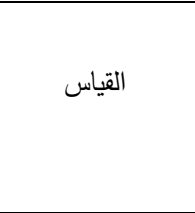 } & \multirow{2}{*}{ المتغيرات / المقاييس الفرعيلة } \\
\hline & & الموجبة & السالبة & 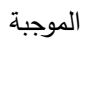 & السالبة & & & \\
\hline 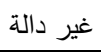 & $1,1 \leq$ & $\varepsilon, 0$ & 10,0 & rer & $\varepsilon, \cdots$ & Ir & بعدي - تتبعي & 1-القلق الصريح · \\
\hline & & & & & & & \multirow{7}{*}{ بعدي بعدي بعدي - بعديعي - بعدي - بتبعي - تبعي } & r-جودة الحياة . \\
\hline غير دالة & - , $\vee 0$ & r,o & $v, 00$ & 1,11 & r,or & Ir & & 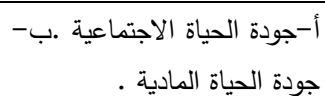 \\
\hline 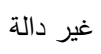 & 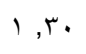 & $10,1 \leqslant$ & $\varepsilon \cdot, 0$ & $r, \varepsilon r$ & $7,0 \leqslant$ & ir & & ج־جودة الحياة الوجدانية . \\
\hline غير دالة & $1, \cdot 1$ & 9,11 & $\varepsilon \varepsilon, \wedge$ & $1, \leqslant$ & $7, \Gamma \varepsilon$ & ir & & د- جودة الحياة الاكاديمية . \\
\hline غير دالة & 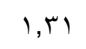 & $r, \ldots$ & מיו & $\wedge, 0 \leq$ & $0, \Sigma \Gamma$ & it & & هـ - الرضا عن الحياة . \\
\hline غير دالة & $1, r_{1}$ & $1 \leq$ & $\leqslant 1, r_{0}$ & $r, \varepsilon r$ & M & ir & & الدرجة الكلية \\
\hline \multirow[t]{2}{*}{ غير دالة } & ס ס, & 0,0 & $1 \cdot, 0$ & $\varepsilon, r_{0}$ & V,r & ir & & \\
\hline & & & & & & & \multirow{5}{*}{ بعدي بعدي - بعدي - تتبعي } & بالسيكوسة "كورنل" للأعراض \\
\hline 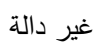 & , or. & $0, \cdots$ & $10, \leqslant 0$ & $\varepsilon, Y r$ & 0,07 & ir & & ا-الجهاز التنفسي . \\
\hline غير دالة & 1,17 & r... & V & $V, \Sigma Y$ & $\varepsilon, T \leq$ & ir & & r-الجهاز الهضمي • \\
\hline غير دالة &, $0 . V$ & $1 \leq, \leq 0$ & $\varepsilon \cdot, 0$ & $\wedge, 01$ & 0,0 & ir & & r-القلب والأوعية . \\
\hline غير دالة & 1,10 & $0 . \ldots$ & v & سז,0 & $\varepsilon, V \vee$ & ir & & الدرجة الكلية . \\
\hline
\end{tabular}

ويتضح من جدول (1) (1) ما يلي : لدئي

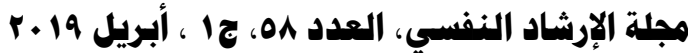

$(1 \vee 0)$ 
تحقق الفرض الثالث حيث أوضحت النتيجة أنه لا توجد فروق دالة احصائيا" بين

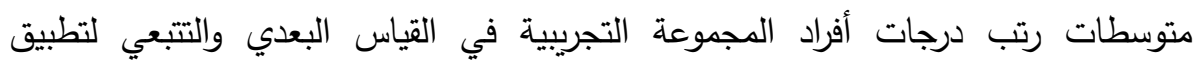

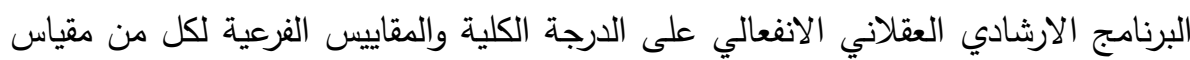

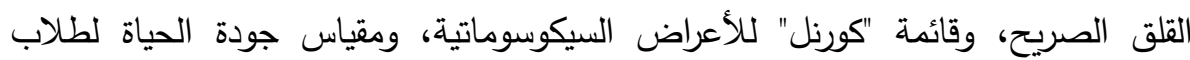
الجامعة .

وتعزوالباحثة هذه النتيجة إلى جدوى وفاعلية أثر البرنامج الارشادي المستخدم وفنياته

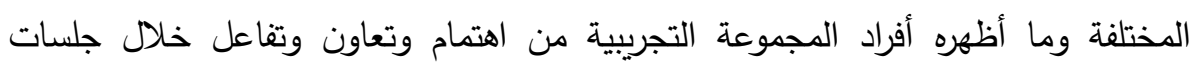

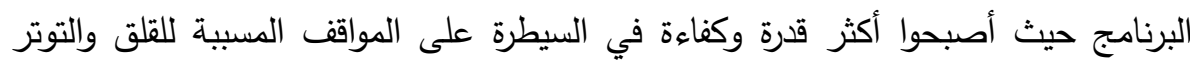
والتحكم فيها، وتغليب طرق التفكير العقلاني والمنطقي والتحكم الذاتي واستخدام طرق حل فل فئي

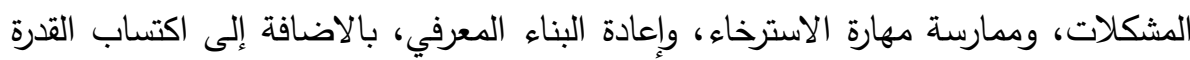
على التعبير عن المشاعر بشكل صريح وبحرية كاملة، ومن خلال كتابة التقارير الذاتية،

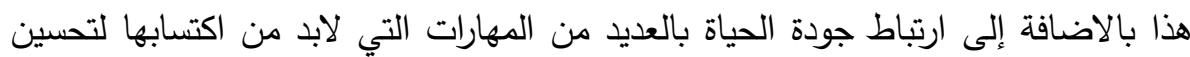

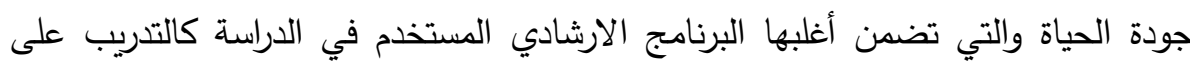
استخدام أساليب التفكير العقلاني والايجابي اللازمة لتحسين الشعور بجودة الحياة، وتعلم

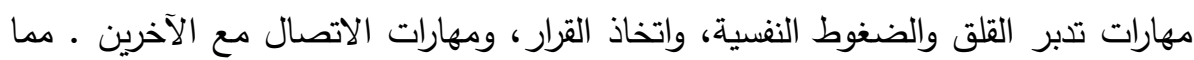

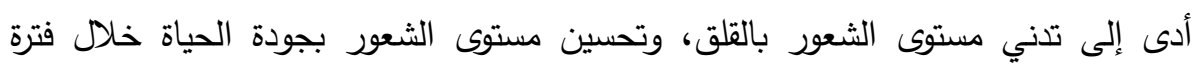

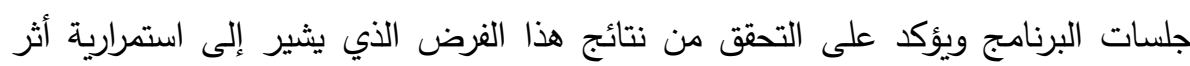
وفاعلية البرنامج حتى بعد الانتهاء منه بفترة تصل إلى شهر • وتبدوهذه النتيجة طبيعية

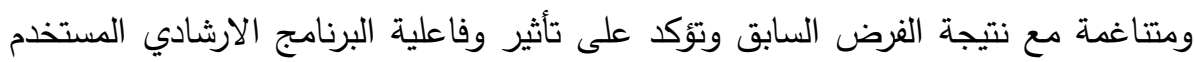
في البحث ـ وتتفق تلك النتيجة مع ما أوضحته نتائج بعض الدراسات من فاعلية ولية المنهج العقلاني الانفعالي في خفض القلق وتحسين مستوى جودة الحياة وخفض الاضطرابات التهات

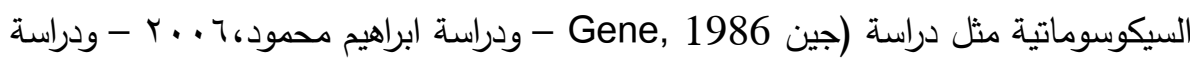

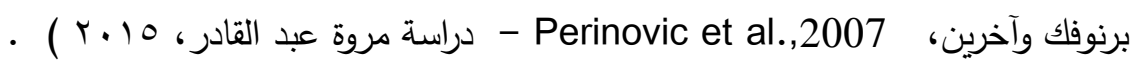

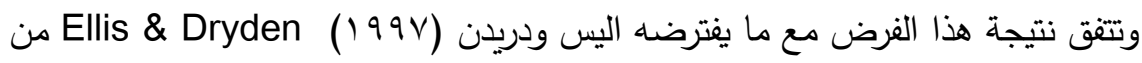
أن أنماط التفكير المتعصبة وغير المنطقية وسوء تأويل وتفسير الفرد للأمور والأحداث التي يمر بها هي التي تسبب له الاضطراب، وإذا استمر الفرد في تبني والتمسك بهذه الأفكار

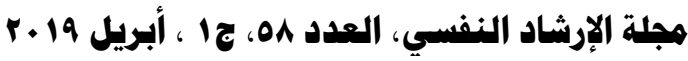




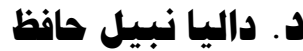

اللاعقلانية وتدعيمها عن طريق التلقين الذاتي يحدث إضطرابه الانفعالي كالقلق والتوتر

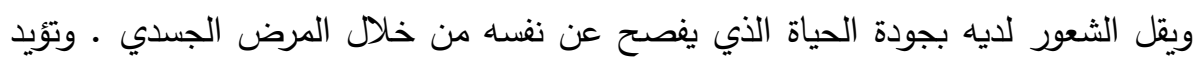

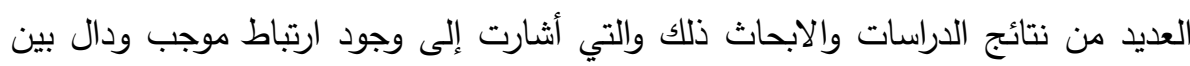

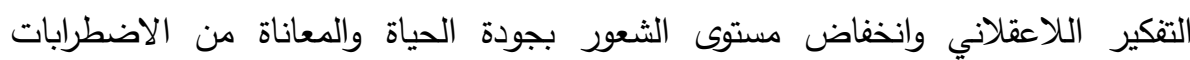

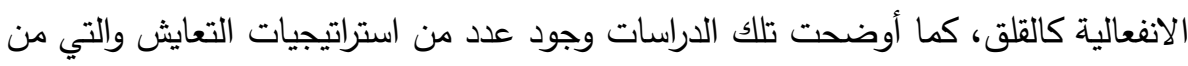

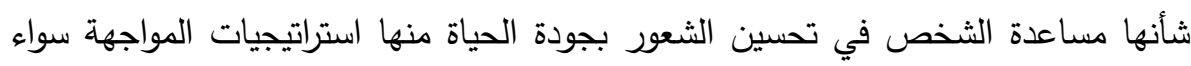

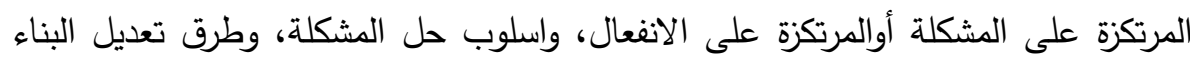

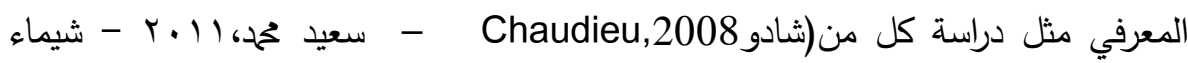

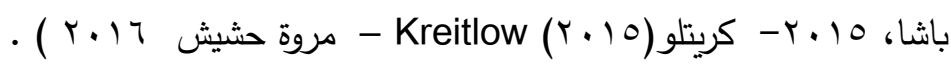

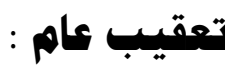

أشارت نتائج البحث الحالي إلى صحة الفروض المتعلقة بالدراسة التجريبية والتي

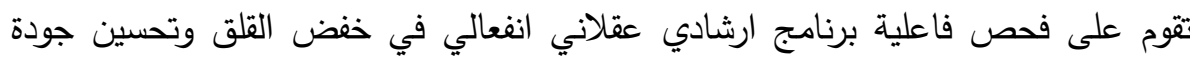

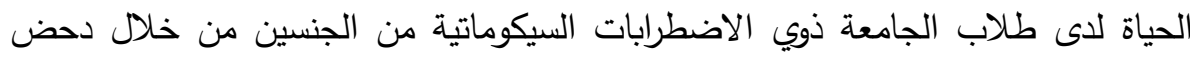

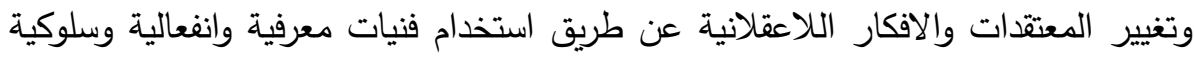
قائمة على نظرية اليس Ellis في الثخصية حيث أظهرت ننائج الدراسة الأثر الفعال

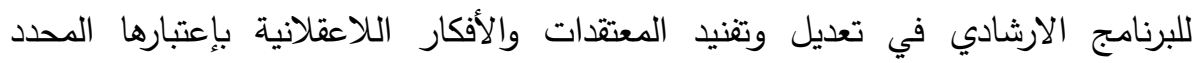

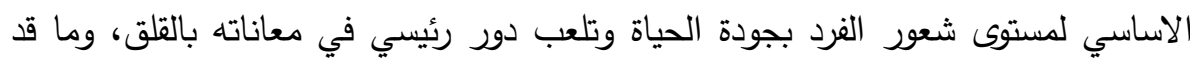

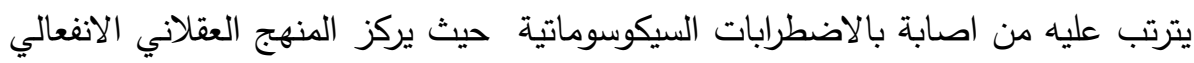

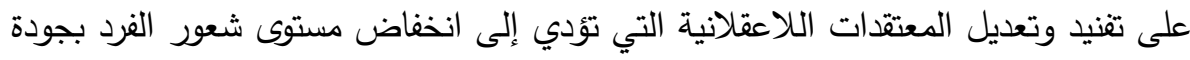

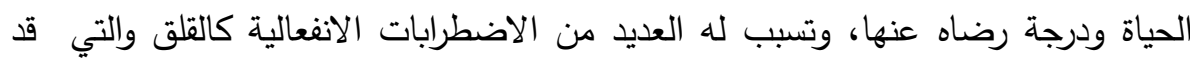

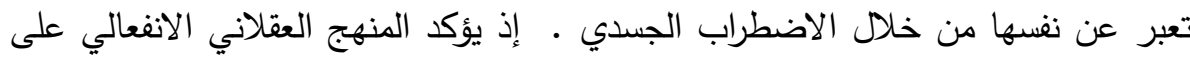

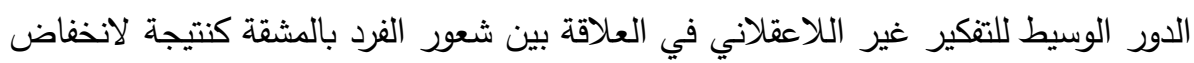

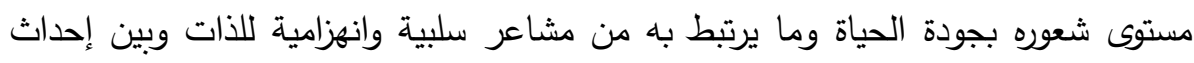

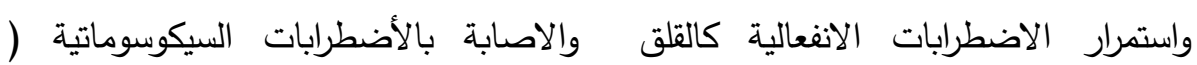
. ( Tsushima,1995 
ومن ثم ترى الباحثة أن جودة الحياة لا تتحقق إلا من خلال التفكير العقلاني الفعال

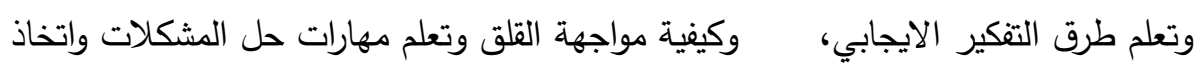
القرار ووضع بدائل ايجابية لحلول المشكلات التي يواجهها الفرد في حياته وتوثيق الصلة ولئل

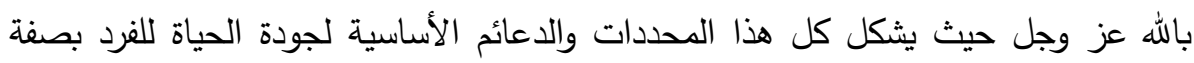

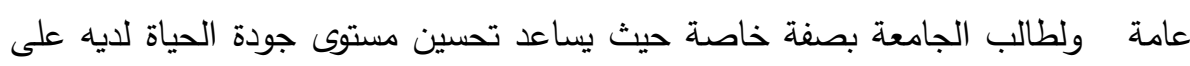
استثار طاقاته وامكاناته بشكل أفضل وتوظيفها في الوجهة المناسبة مما يعود بالنفع العام • على المجتمع : التوصيات : في اطار ما أثارته نتائج البحث الحالي نوصي بعدة توصيات كما يلي :

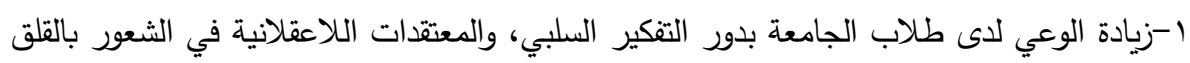

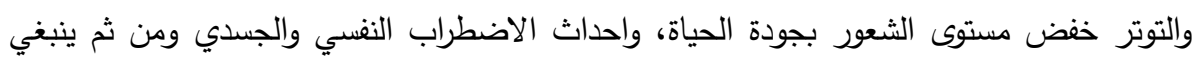
توفير برامج ارشادية معرفية تهدف إلى التدريب على تعديل الأفكار والمفاهيم الخاطئة واستخدام

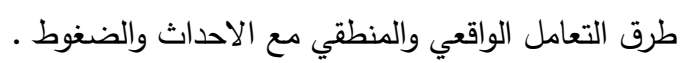

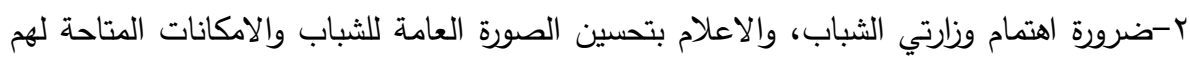
واتاحة الفرص لهم لاكتساب معارف ومهارات تتاسب مع تخصصاتهم وقدراتهم وتساعدهم على ولى واتلان

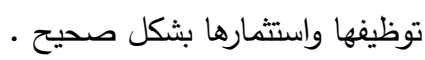
r-ضرورة الاهتمام بجوانب ومكونات جودة الحياة مما ينعكس بدوره ايجابيا على تحسين مستوى تصى

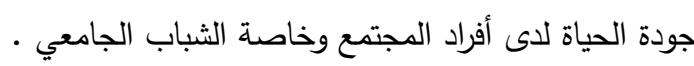

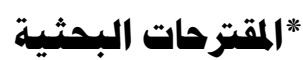
وفقا لما اثارته الدراسة من نتائج توصي الدراسة الحالية بإجراء العديد من الدراسات

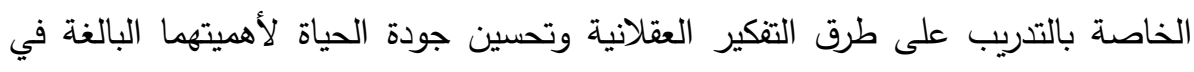
الاعداد السليم لطلاب الجامعة بإعتبارهم اساس نموتطور المجتمع • ومن هذ المقترحات البحثية : - n

1-تصميم برامج ارشادية معرفية لتحسين جودة الحياة لدى الثباب من مدمني الانترنت . ب-فاعلية العلاج المعرفي في تحسين جودة الحياة لدى طلاب الجامعة المضطربين معرفيه نفسيا"

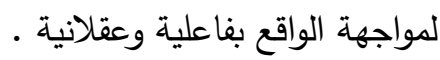

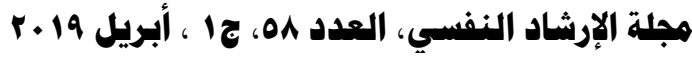




\section{د. داليا نبيل حافظ}

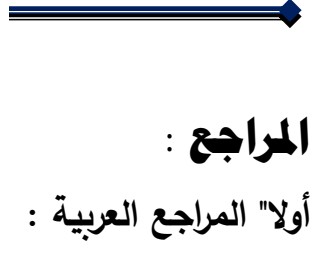

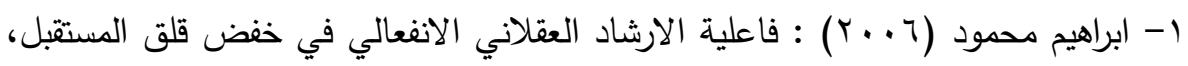
لاى طلاب التعليم الفني، سالة ماجستير غير منشورة، كلية التربية، جامعة أسيوط .

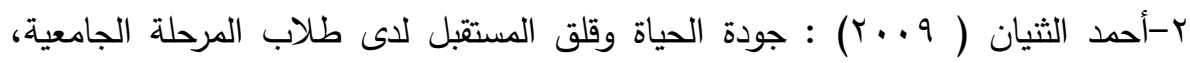
رسالة دكتوراه، كلية التربية، جامعة ام القرى •

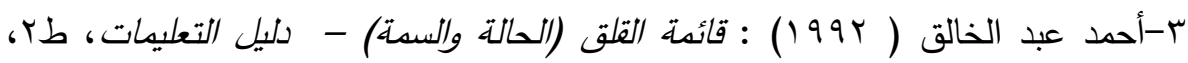

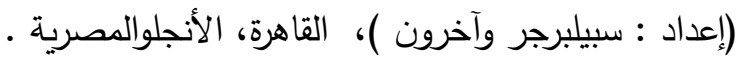

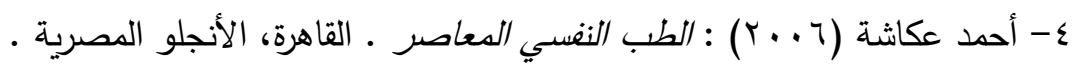

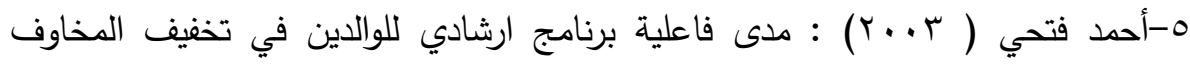

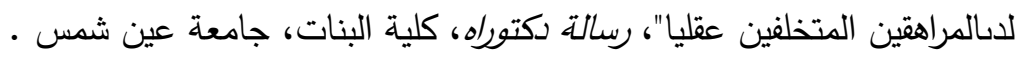
צ- أمال صادق وفؤاد أبوحطب (.99 (1) : نمو الانسان من مرحلة الجنين إلى مرحلة

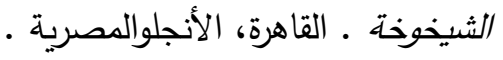

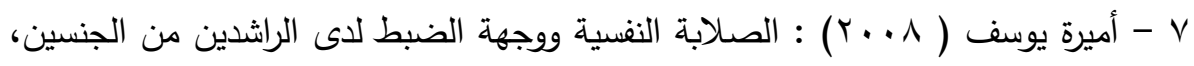

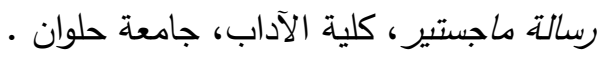

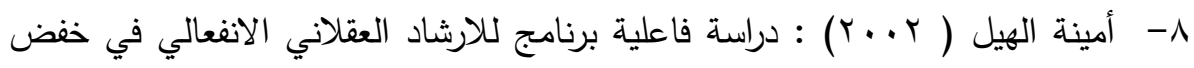

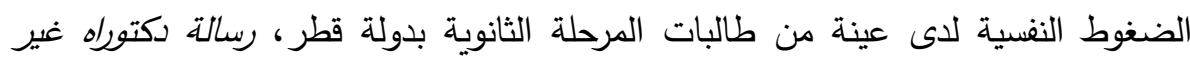
منشورة، كلية التربية، جامعة عين شمس 9 -باترسون،س،ه (999 (19) : نظريات الاشاد والعلاج النفسي، ترجمة : حادد عبد العزيز

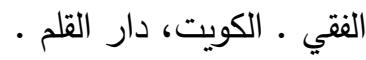

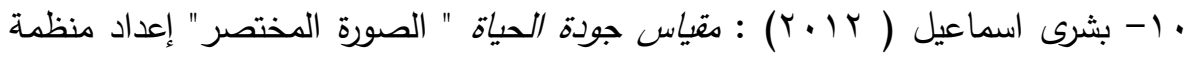

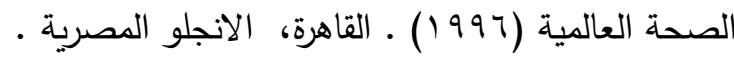

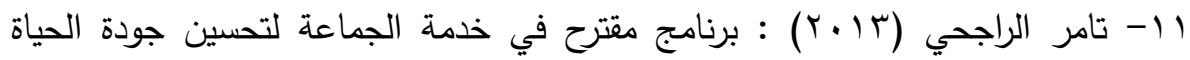
للأطفال المعاقين ذهنيا" ذوي صعوبات التعلم، دراسة وصفية مطبقة على مدرسة التربية 


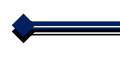

الفكرية بالمنصورة، المؤتمر العلمي الدولي السادس والعشرون للخدمة الاجتماعية وتطوير

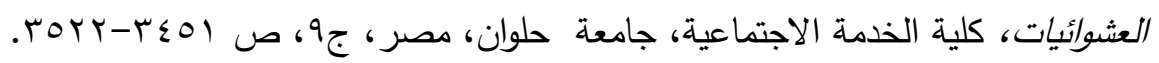

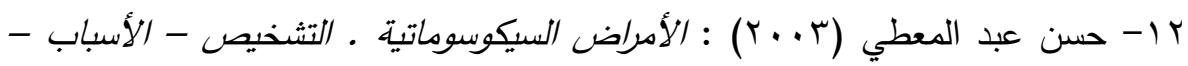
العلاج • القاهرة، زهراء الشرق .

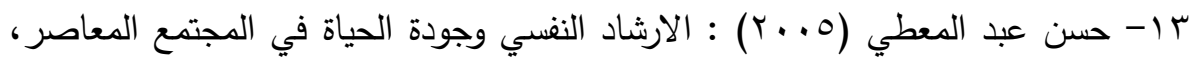
الموتمر العلمي الثالث لكلية التربية جامعة الزقازيق، " الانماء النفسي التربوي للإنسان

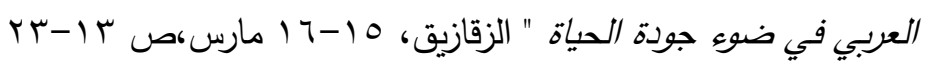

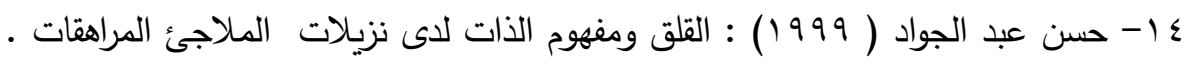
"دراسة اكليكية"، رسالة دكتوراه كلية الآداب، جامعة عين شمس •

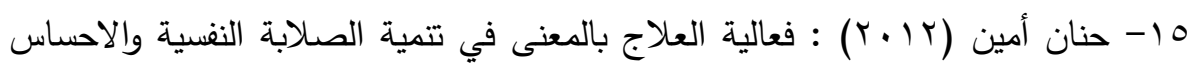
بجودة الحياة لدى عينة من المراهقات الكفيفات بمدينة مكة المكرمة، رسالة دكتوراه، كلية

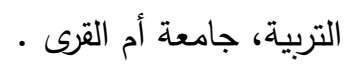

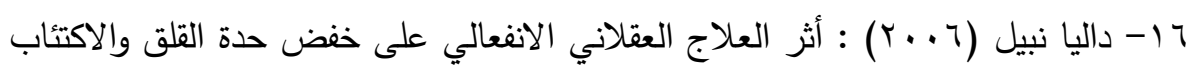

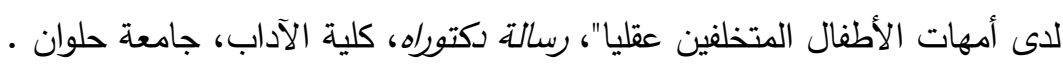

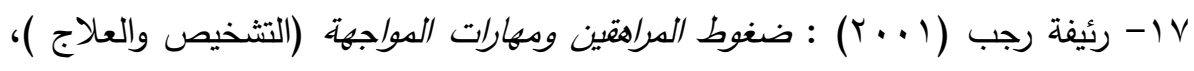
القاهرة، مكتبة النهضة المصرية

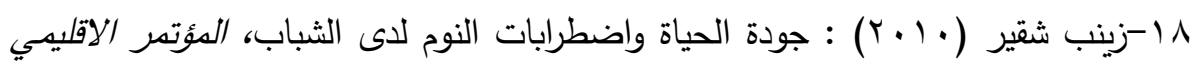

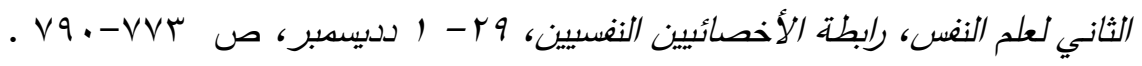

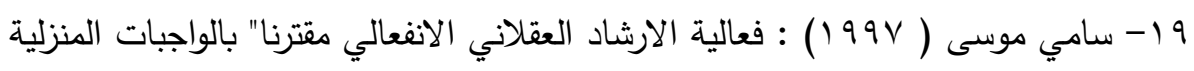

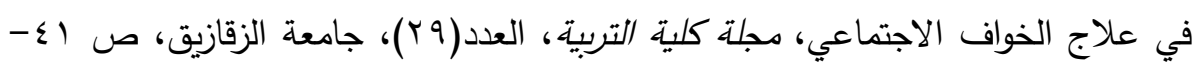

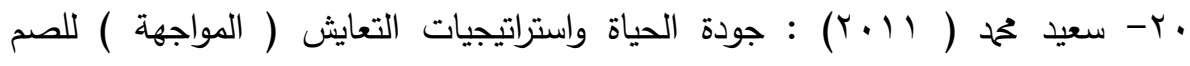

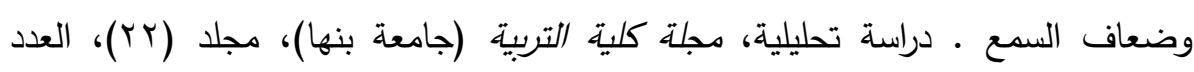

$$
\text { . ro. -r) (Av) }
$$

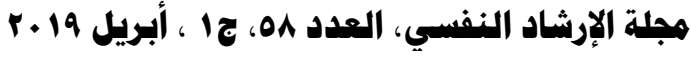




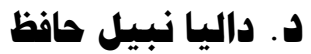

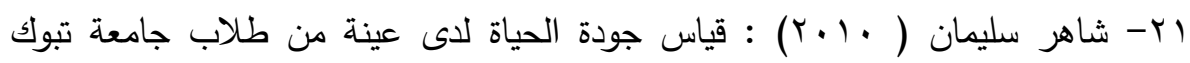
بالمملكة العربية السعودية وتأثير بعض المتانيان (الثيرات عليها، رسالة الخليج العربي، السعودية،

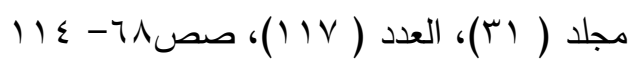

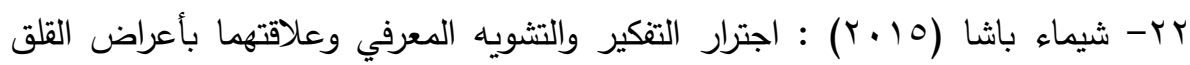

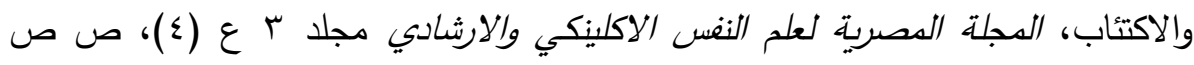
. ONt -OTA

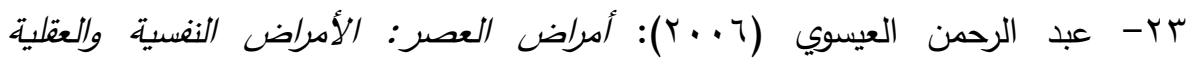
والسيكوسوماية ـ الأسكندرية، دار المعرفة الجامعية .

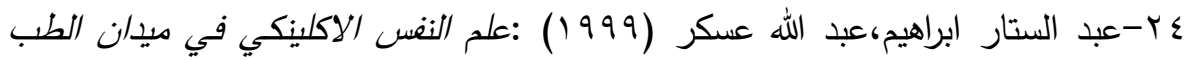
النفسي، القاهرة، الأنجلو المصرية. Or- علاء الدين كفافي (1999) : الاششاد والعلاج النفسي الأسري، الدنظور النسقي

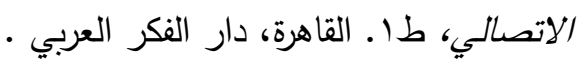

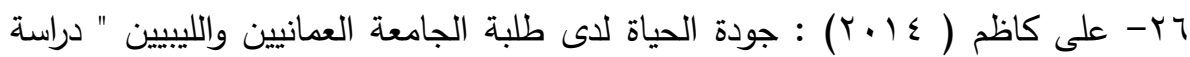
ثقافية مقارنة"، كلية التربية لجامعة السلطان قابوس، وجامعة عمر المختار، مجلة الأكاديية

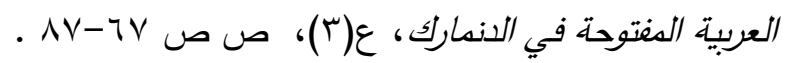
YV العلاقة بين ضغوط الحياة وأعراض القلق والاكتئاب، سالة دكتوراه، كلية الآداب، جامعة الضعان

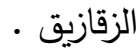

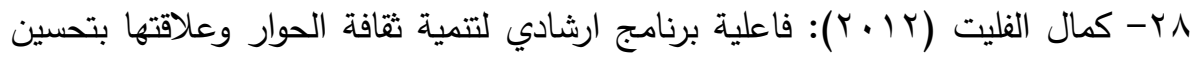
جودة الحياة لاى طلاب جامعة فلسطين، رسالة دكتوراه، معهد الدراسات التربوية، جامعة التادية

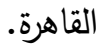
9 - لويس مليكة (ب99 (1)): علم الننس الاكلينكي، القاهرة، الهيئة المصرية للكتاب.

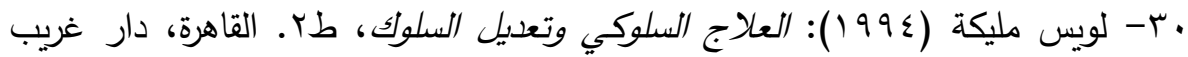

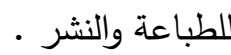

اب- ماجدة خميس (Y991)): القلق النفسي وعلاقته ببعض الأمراض العضوية (دراسة عاملية)، رسالة دكتوراه غير منشورة، كلية الآداب، جامعة الأسكندرية.

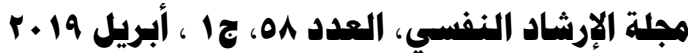


r ب- مروة حشيش (T 1 • Y): الفروق بين طلاب الجامعة تبعا" لمستويات الاحساس بجودة

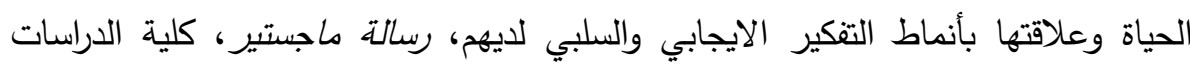
العليا للتربية، جامعة القاهرة. r r- مروة عبد القادر (10 • (10): فاعلية برنامج ارشادي عقلاني انفعالي لتحسين جودة

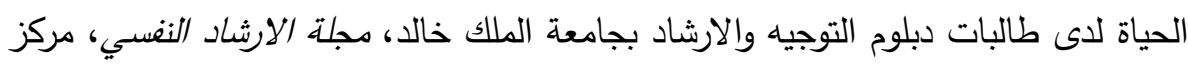

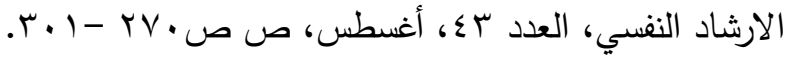

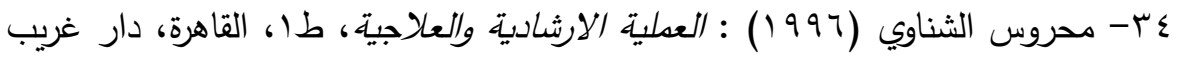

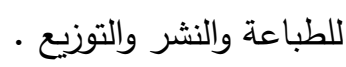

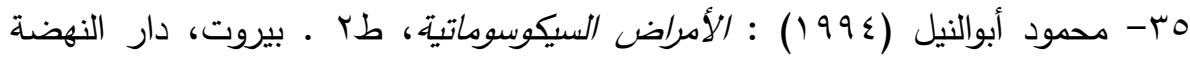

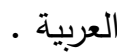

بس- محمود أبوالنيل (1990) : قائمة كورنل للاضطرابات السيكوسوماتية . القاهرة،

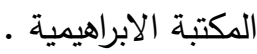
VT - مصطفى فهمي، ومحمد غالي ( • .99 (): مقياس "تايلور" للقلق الصريح، القاهرة، دار النهضة العربية . ^ץ- مددوحة سلامة (910 (1): الاشاد النغسي • منظور /نعائي ـ القاهرة، الأنجلوالمصرية

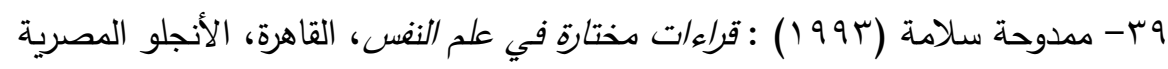

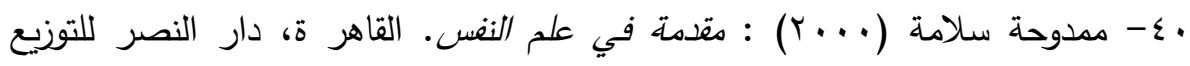
• والنشر اء- نيفين نيروز (T (†): الأسلوب المعرفي كمتغير معدل للعلاقة بين المشقة والاضطرابات النفسية الجسمية، رسالة ماجستير غير منشورة، كلية الآداب، جامعة القاهرة

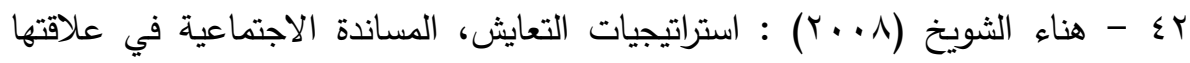
ببعض الاختلالات النفسية لدى مرضى أورام المثانة السرطانية، رسالة ماجستير، كلية

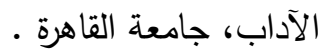

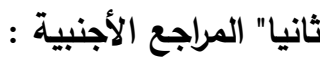
43- Abd El-Khalek, A.(2003). Somatic symptoms inventory (SSI) : Development, Paraneters and correlates. Current Psychiatry, Vol. 10,114-129.

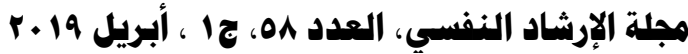


44-Abramson, L . Y., Seligman, M, Em. \& Tesasdale, J. O., (1978). Learned helplessness in humans critique and reformulation. Journal of Abnormal Psychology. 87, 1,49-74.

45 - Andersen,B .L.,(2003).Psychological Interventions for Cancer Patients to Enhance the quality of life. Journal of Consulting and Clinical Psychology, 60(4), 552-568.

46- Arslan, S.,\& Akkas,O.A. (2013) . Qualit of college life (QCL) of students in Turkey: students" life satisfaction and identification. Social indicators research, 115 (2), 869-884.

47-Beck, A. t., (1989). Forewod. In. J. Scotte, M. Williams \& A. Beck, (Eds.), Cognitive therapy in Clincal Practice. London : Routledge .

48 - Bootzin ,R., Alloy , L . B. \& Aciculae, J. (1993) .Abnormal Psychology Current spective. New York : Mc Graw Hill, Inc.

49-Bronsard. G, Lancon. C, Loundou.a, rufo. M, Tordjman. SSimeoni. C.m(2013). Quality of life and mentaldisorders of adolescents living in french residential group hhomes, Child Welfare, Vol.92,No.3.

50 -Corsini. R.J ia of \&Auerbach.A.J.,(1996). Corsini Encyclopedia of Psychology (2ed). New York : John Wiley\&Sons.

51 -Davison,G. C\& Neal, J. M., (1994) . Abnormal Psychology . (6 ed). New York: Joh Wiley \& Sons .

52-Dolliver, R.H., (1977) . The Relationship of rational - emotive therapy to other psychotherapies and personality theories. The Counseling psychologist, 7,1, 57-63.

53-Donovan, A.M.,(1988).Family stress and ways of coping with adolescents who have andicaps : Menternal perception. American Journal of Mental Retardation.92,6,502-509

54-Dryden, W. \& Digiuseppe, R., (1990) : A Primer on rational emotive therapy. Illinois: Research Press .

55-Ellis, A.,(1990). Rational and irrational beliefs in counseling psychology. Journal of Rational Emotive and Cognitive Behavior Therapy , 8, 3, 221-233

56-Ellis.A. \& Dryden , W., (1997). The Practice of rational emotive therapy . (2 ed) . New York : Springer Publishing .

57 -Gene. P. ( 1986). Rationality as a moderator between life events and illness. J. of American College Health, Vol 34 , N4, PP 170-173.
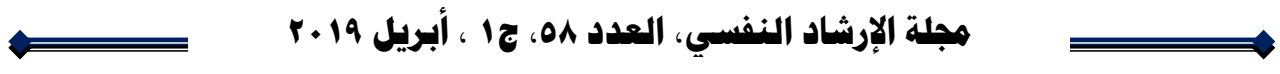
58-Ghaedi, G, H., Tavoli, A., Bakhtiari, M., Melyani, M., \& Sahragardm M.(2010). Quality of life in college students with and without social phobia-social indicators research, 97(2), 247-256.

59-Gramer, D. \& Buckland., N., (1995). Effect of rational and irrational statements and demand characteristics of tas; anxiety . Journal of psychology, 129, 3, 369-378.

60-Greenberge, R.L., (1989). Panic disorder and agoraphobia in :J, Scotte; J, Mark \& A, T. Beck., (Eds.), Cognitive Therapy in clinical practice. An Illustrative Casebook. New York :Rutledge .

61- Klassen, A., Miller, A., \& Fine,S. (2004) : Health-Related Quaility of life in children and adolescents who have a diagnosis of attention deficit L Hyperactivity Disorder. Pediatrics114, 541-517.

62-Kreitlow, Abby (2015).Religiosity and subjective quality of life amongselected university students, Minnesota state university, Mankato. Health Education United State, Ann Arbor Degree : M.S. (2015),P.90

63- Margan, R. (2003) : Asystems thinking paradigm and leaning computers emulation model of the positive and negative feedback structure underlying growth Eric.

64 -Nielsen, S.L; Johnson, W.B. \& Ridley, C.R., (2000). Religiously sensitive rationl emotive behavior therapy theory techniques, and brief excerpts froma case. American Psychological Association, 31, 1, 2128

65- Norouzi, M., (2012). Relationship of quality of life and achievement motivation with under graduated students anxiety, Scientific Reports ,1 (1) ,6-10.

66-Perinovic, E. ; Mickic; Z., \& Kozja; ( 2007) . C0gnitive stress coping strategies \& Psychosomatic symptoms in adolescents. J. of Social Psycgology, Vol.35, 126-132.

67 -Piko B. \& Noemi K. (2006). Psycholoso matic symptom formation as a health status indicator in early adolescence: behavioral epidemiologig analysis . Orv Heil. Vol . 7:147(18): 819-825.

68- Schalock N. (2002): Handboo; of quality of life for Human service practitioners, American Association of Mental Retardation , Washington, D. C.

69- Taylor, SH. (1999).Health Psychology. Lo s Angeles : McGrawHill

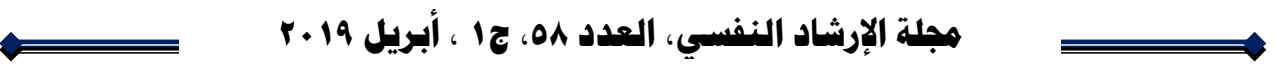


70-Tsushima, V,G.,(1995). The Effect of rational emotive therapy and supportive therapy on correlates of adolescent depression. Abstract International , 56, 1, 539-577.

71-Verdugo. A.M, Navas.P.,Gomez. E.L. \& Schalock.L.R(2012). The concept of quality of life and its role in enhancing human rights in the field of intellectual disability, Journal of Intellectual Disability Research, Vol (56) Part (11) PP 1036-1045.

72-Wenqing; Jing; Zhang \& Hua. (2004). Psychosomat Ic symptoms \& coping styles \& Their influences on quality of lie in chronic hepatitis . J, of Clinical Psychology, Vol.12, 3, 281-283.

73 -Williams, M;Watts, F; Macleod, C. \& Mathew, A., (1997).Cognitive Psychology and Emotional Disorder. New York : Chichester Wiley. 
Effectiveness of Rational Emotive Guidance Program on Reduction of The Symptoms of Anxiety and improving the quality of life among University Students of psychosomatic disorders

\begin{abstract}
Study
The aim of this research is to verify the effectiveness of the used Rational Emotive Guidance program on Reduction of The Symptoms of Anxiety and improving the quality of life among University Students of psychosomatic disorders , The sample consists of (24) students,age ranged from (18-23) years, divided into two groups : experimental $(n=12)$, and control $(n=12)$

The researcher used Taylor Manifest Anxiety Scale prepared by ( Janit.Taylor),translated and prepared by ( Motafa fahmy \& Mohomamed Kally, 1990), quality of life among University Students scale prepared by( Kamal Eflit, 2012), Cornell index prepared ( Albert \& Brodman,1986), translated and prepared by ( Mohmoud Abo Elneel,1995), and program to Reduction of The Symptoms of Anxiety and improving the quality of life among University Students prepared by ( the researcher ).
\end{abstract}

Dalia Nabil Hafez

The results of this research lead to statistically significant difference between mean score of experimental and control groups ( post Administration Program ) 1n Taylor Manifest Anxiety Scale ,Cornell index and quality of life among University Students scale, There are a statistically significant differences between the mean scores of pre and post program administration in experimental group in Anxiety, Cornell index and quality of life among University Students scale, and No significant differences were found between the mean scores of post and follow up measures program administration for experimental group in Anxiety, Cornell index and quality of life among University Students scale, Which refers to the The Effectiveness of Rational Emotive Guidance Program on Reduction of The Symptoms of Anxiety and improving the quality of life among University Students of psychosomatic disorders.

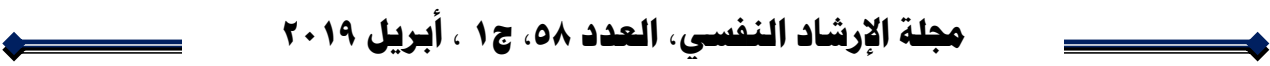

